\title{
TRANSMISSÃO DE PREÇOS ENTRE PRODUTOS DO SETOR SUCROALCOOLEIRO DO ESTADO DE SÃO PAULO
}

\author{
LUCILIO ROGERIO APARECIDO ALVES
}

Dissertação apresentada à Escola Superior de Agricultura "Luiz de Queiroz", Universidade de São Paulo, para obtenção do título de Mestre em Ciências, Área de Concentração: Economia Aplicada

P I R A C I C A B A

Estado de São Paulo - Brasil

Novembro - 2002 


\title{
TRANSMISSÃO DE PREÇOS ENTRE PRODUTOS DO SETOR SUCROALCOOLEIRO DO ESTADO DE SÃO PAULO
}

\author{
LUCILIO ROGERIO APARECIDO ALVES
}

Bacharel em Ciências Econômicas

Orientador: Profa. Dra. MIRIAN RUMENOS PIEDADE BACCHI

Dissertação apresentada à Escola Superior de Agricultura "Luiz de Queiroz", Universidade de São Paulo, para obtenção do título de Mestre em Ciências, Área de Concentração: Economia Aplicada

P I R A C I C A B A

Estado de São Paulo - Brasil

Novembro - 2002 


\section{Dados Internacionais de Catalogação na Publicação (CIP)} DIVISÃO DE BIBLIOTECA E DOCUMENTAÇÃO - ESALQ/USP

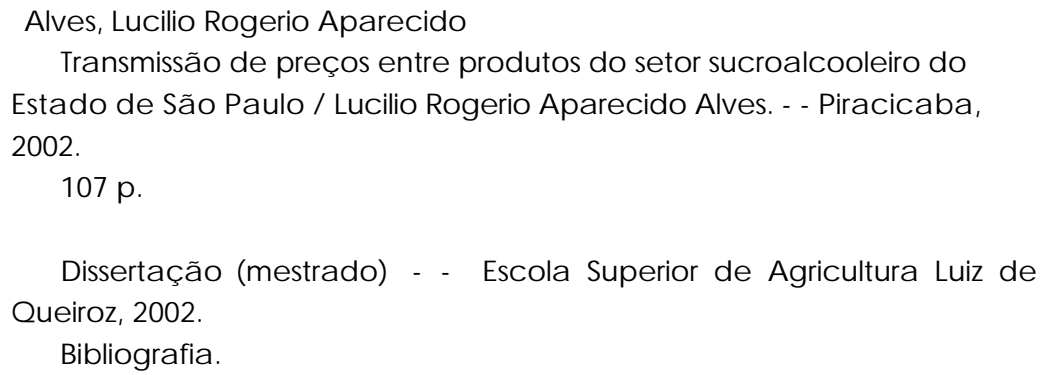

1. Açúcar 2. Álc ool 3. Comercia liza ção a gńc ola 4. Indústria suc roalc ooleira 5. Preçosagńc olas 6. Produto agroindustrial I. Título

CDD 338.476641

\section{"Permitida a cópia total ou parcial deste documento, desde que citada a fonte - $O$ autor'}


Aos meus pais, em reconhecimento a toda uma vida de apoio, incentivo e amor. Ao Lucindo, Lucir e Alessandra, dedico. 


\section{AGRADECIMENTOS}

Á Deus, por ter me dado capacidade, força e condições física e espiritual, possibilitando vencer mais essa etapa em minha vida.

Aos meus familiares, por todo apoio, dedicação, carinho e confiança, aos quais serei eternamente grato. À Alessandra, em quem encontrei amor e paz de que tanto precisei para a finalização do trabalho.

Agradecimentos especiais à Profa. Dra. Mirian Rumenos Piedade Bacchi pela orientação com dinamismo, clareza e paciência, que será sempre lembrada. Muito obrigado.

Ao Prof. Dr. Geraldo Sant'Ana de Camargo Barros, à Profa. Dra. Helíosa Lee Burnquist e à Dra. Marta Cristina Marjotta-Maistro pela atenção, prestatividade e sugestões sempre valiosas para o presente trabalho.

Aos demais professores do Departamento de Economia e Sociologia Rural da ESALQ/USP, pela oportunidade de participar do Programa de Pós-Graduação, possibilitando maior aprendizado e desenvolvimento profissional. À Profa. Dra. Zilda Paes de Barros Mattos, pela supervisão na monitoria durante o ano de 2002.

A todos os funcionários deste Departamento, especialmente à Maielli.

Àqueles que deram-me apoio, especialmente de moradia, nos meses iniciais do curso de Pós-Graduação: Ricardo, Alexandre, Jefferson e Jaínes. Aos moradores da Vila da Pós-Graduação da ESALQ/USP, em especial ao Paulo, Julcemar, Nailton e Clodoaldo.

Enfim, a todos os colegas da Pós-Graduação, principalmente àqueles que me ajudaram de uma forma ou de outra.

Ao Conselho Nacional de Desenvolvimento Científico e Tecnológico - CNPq pelo apoio financeiro. 


\section{SUMÁRIO}

Página

LISTA DE FIGURAS .............................................................................. vii

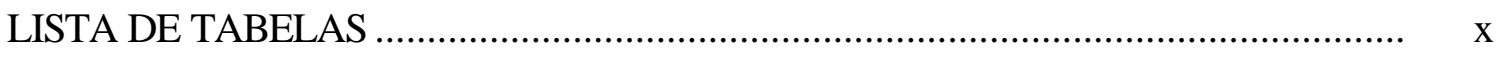

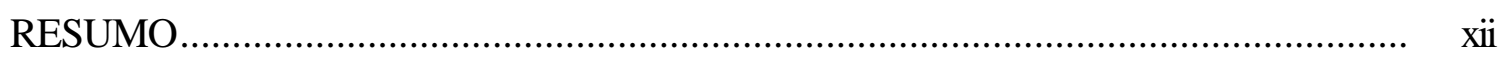

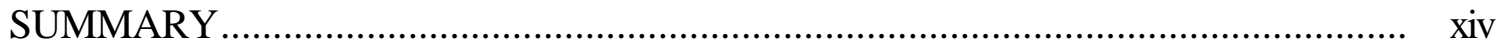

1 INTRODUÇÂÃ

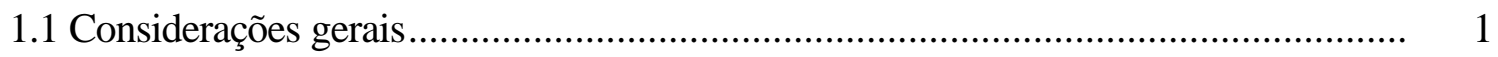

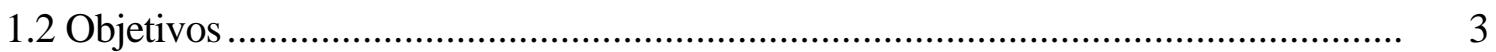

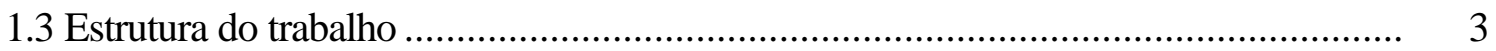

2 REVISÃO DE LITERATURA ..................................................................... 4

2.1 Evolução do complexo agroindustrial canavieiro no Brasil....................................... 4

2.2 Aspectos do setor sucroalcooleiro nacional e açucareiro mundial............................... 8

2.2.1 O setor açucareiro nacional e mundial........................................................... 9

2.2.2 $\mathrm{O}$ setor alcooleiro nacional ...................................................................... 13

2.2.3 Comercialização do açúcar e do álcool nacionais .............................................. 14

2.2.3.1 Análise dos preços do açúcar e do álcool ................................................... 20

2.3 Trabalhos voltados à análise do comportamento de preços e comercialização de produtos agropecuários ............................................................................ 24

3 REFERENCIAL METODOLÓGICO E MODELOS ECONÔMICOS .................... 30

3.1 Modelos econômicos ................................................................................. 30

3.1.1 Modelo de Gardner (1975) ......................................................................... 30

3.1.2 Modelo de Heien (1980) ............................................................................ 32

3.1.3 Modelo de Barros (1990) ............................................................................... 37

3.2 Modelo econômico proposto................................................................................. 40 
3.2.1 Fonte dos dados .................................................................................... 47

3.3 Procedimentos .......................................................................................... 48

3.3.1 Testes de raiz unitária .................................................................................. 49

3.3.2 Testes de co-integração e mecanismo de correção de erro .................................. 53

3.3.2.1 Método de Engle \& Granger ........................................................................ 54

3.3.2.2 Método de Johansen............................................................................... 55

3.3.3 Modelo Auto-Regressivo Vetorial (VAR) ......................................................... 57

3.3.3.1 Modelo VAR convencional ...................................................................... 58

3.3.3.2 Modelos VAR estruturados e/ou identificáveis ................................................... 62

4 RESULTADOS E DISCUSSÃO .................................................................. 64

4.1 Testes de raiz unitária .................................................................................... 65

4.2 Modelos de Auto-Regressão Vetorial com Correção de Erro (VEC) com identificação pelo processo de Bernanke.................................................................. 67

4.2.1 Modelo 1: influência contemporânea do preço do açúcar cristal industrial sobre os preços do açúcar cristal exportado e do álcool anidro.

4.2.2 Modelo 2: influência contemporânea do preço do álcool anidro sobre os preços do açúcar cristal exportado e do açúcar cristal industrial............................. 72

4.2.3 Modelo 3: influência contemporânea do preço do açúcar cristal empacotado ao varejo sobre o preço do açúcar cristal empacotado ao produtor.

4.2.4 Modelo 4: influência contemporânea do preço do açúcar cristal exportado sobre o preço do açúcar cristal industrial............................................................ 80

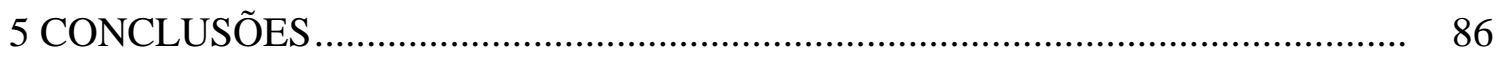

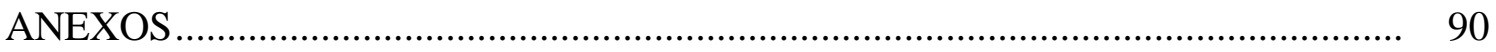

REFERÊNCIAS BIBLIOGRÁFICAS _......................................................... 98 


\section{LISTA DE FIGURAS}

Página

1 Esquema simplificado da comercialização de açúcar e álcool combustível no Brasil.....

2 Evolução dos preços do açúcar cristal industrial (ind), cristal empacotado ao produtor (emp) e refinado ao produtor (rep), de maio/1998 a jun./2002.

3 Evolução dos preços do açúcar no mercado interno ao produtor (ind e emp) e externo (exp), de maio/1998 a jun./2002

4 Evolução dos preços dos açúcares cristal empacotado (emv) e refinado (rva), ao varejo, maio/1998 a abr./2002

5 Evolução dos preços dos alcóois anidro (ani) e hidratado (hidr), ao produtor, maio/1998 a jun./2002

6 Evolução dos preços do álcool anidro (ani) e do açúcar cristal industrial (ind), em termos de R\$/ATR, maio/1998 a jun./2002.

7 Representação simplificada das inter-relações entre os mercados do setor sucroalcooleiro brasileiro.

8 Interdependência entre os mercados de açúcar e álcool.

9 Matriz de relações contemporâneas

10 Função de resposta dos preços do açúcar cristal industrial (ind), do álcool anidro (ani), do açúcar cristal exportado (exp) e do açúcar cristal empacotado ao produtor (emp), à impulso no preço do açúcar cristal industrial (Modelo 1).........

11 Função de resposta dos preços do açúcar cristal industrial (ind), do álcool anidro (ani) e do açúcar cristal exportado (exp), à impulso no preço do álcool anidro (Modelo 1).

12 Função de resposta dos preços do açúcar cristal industrial (ind), do álcool 
anidro (ani) e do açúcar cristal exportado (exp), à impulso no preço do açúcar cristal exportado (Modelo 1)

13 Função de resposta dos preços dos açúcares cristal industrial (ind), do cristal exportado (exp) e do cristal empacotado ao produtor (emp) e ao varejo (emv), àimpulso no preço do açúcar cristal empacotado ao produtor (Modelo 1)

14 Função de resposta dos preços do açúcar cristal industrial (ind) e do açúcar cristal empacotado ao produtor (emp) e ao varejo (emv), à impulso no preço do açúcar cristal empacotado ao varejo (Modelo 1)

15 Função de resposta dos preços do açúcar cristal industrial (ind), do álcool anidro (ani), do açúcar cristal exportado (exp) e do açúcar cristal empacotado ao produtor (emp), à impulso no preço do açúcar cristal industrial (Modelo 3)

16 Função de resposta dos preços do açúcar cristal industrial (ind), do álcool anidro (ani) e do açúcar cristal exportado (exp), à impulso no preço do álcool anidro (Modelo 3).

17 Função de resposta dos preços do açúcar cristal industrial (ind), do álcool anidro (ani) e do açúcar cristal exportado (exp), à impulso no preço do açúcar cristal exportado (Modelo 3)

18 Função de resposta dos preços dos açúcares cristal industrial (ind), do cristal exportado (exp) e do cristal empacotado ao produtor (emp) e ao varejo (emv), àimpulso no preço do açúcar cristal empacotado ao produtor (Modelo 3)

19 Função de resposta dos preços do açúcar cristal industrial (ind) e do açúcar cristal empacotado ao produtor e ao varejo, à impulso no preço do açúcar cristal empacotado ao varejo (Modelo 3)

20 Função de resposta dos preços do açúcar cristal industrial (ind), do álcool anidro (ani), do açúcar cristal exportado (exp) e do açúcar cristal empacotado ao produtor (emp), à impulso no preço do açúcar cristal industrial (Modelo 4)..........

21 Função de resposta dos preços do açúcar cristal industrial (ind), do álcool anidro (ani) e do açúcar cristal exportado (exp), à impulso no preço do álcool anidro (Modelo 4).

22 Função de resposta dos preços do açúcar cristal industrial (ind), do álcool 
anidro (ani) e do açúcar cristal exportado (exp), à impulso no preço do açúcar

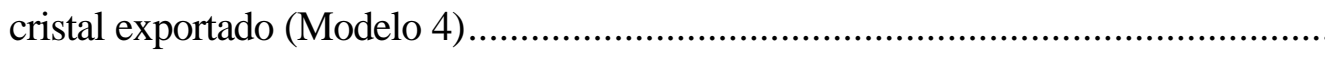

23 Função de resposta dos preços dos açúcares cristal industrial (ind), do cristal exportado (exp) e do açúcar empacotado ao produtor (emp) e ao varejo (emv), à impulso no preço do açúcar cristal empacotado ao produtor (Modelo 4) ...............

24 Função de resposta dos preços do açúcar cristal industrial (ind) e do açúcar cristal empacotado ao produtor (emp) e ao varejo (emv), à impulso no preço do açúcar cristal empacotado ao varejo (Modelo 4) 


\section{LISTA DE TABELAS}

Página

1 Evolução da quantidade produzida e exportada de açúcar pelo mundo e pelo Brasil, 1992/93 a 2000/01 (milhares de toneladas métricas) ............................... 10

2 Quantidade, valor e preço de exportação de açúcar brasileiro, 1989 a 2001 ........... 11

3 Evolução da produção de álcool no Brasil e percentual de cana-de-açúcar convertida em açúcar, de 1970/71 a 2000/01................................................. 14

4 Distribuição do consumo de açúcar no Brasil...................................................... 19

5 Descrição das variáveis utilizadas na presente pesquisa ...................................... 65

6 Resultados dos testes de raiz unitária de Dichey-Fuller para as séries de preços lnani, lnind, lnexp, lnemp e lnemv ...................................................... 66

7 Resultados dos testes de co-integração de Johansen entre as séries de preços lnani, lnind, lnexp, lnemp e lnemv ............................................................ 67

8 Estimativa da matriz de coeficientes de relações contemporâneas (Modelo 1).......... 68

9 Decomposição histórica da variância do erro de previsão para o preço do açúcar cristal industrial (Modelo 1) ................................................................. 71

10 Decomposição histórica da variância do erro de previsão para o preço do

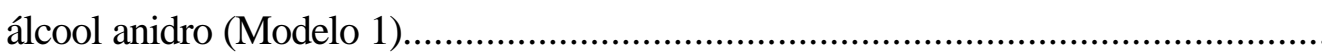

11 Decomposição histórica da variância do erro de previsão para o preço do açúcar cristal exportado (Modelo 1)

12 Decomposição histórica da variância do erro de previsão para o preço do açúcar cristal empacotado ao produtor (Modelo 1)

13 Decomposição histórica da variância do erro de previsão para o preço do açúcar cristal empacotado ao varejo (Modelo 1) .............................................. 73

14 Estimativa da matriz de coeficientes de relações contemporâneas (Modelo 2).......... 75 
15 Estimativa da matriz de coeficientes de relações contemporâneas (Modelo 3).......... 76

16 Decomposição histórica da variância do erro de previsão para o preço do açúcar cristal industrial (Modelo 3) ........................................................... 78

17 Decomposição histórica da variância do erro de previsão para o preço do álcool anidro (Modelo 3)

18 Decomposição histórica da variância do erro de previsão para o preço do açúcar cristal exportado (Modelo 3)

19 Decomposição histórica da variância do erro de previsão para o preço do açúcar cristal empacotado ao produtor (Modelo 3)

20 Decomposição histórica da variância do erro de previsão para o preço do açúcar cristal empacotado ao varejo (Modelo 3) ............................................... 79

21 Estimativa da matriz de coeficientes de relações contemporâneas (Modelo 4).......... 80

22 Decomposição histórica da variância do erro de previsão para o preço do açúcar cristal industrial (Modelo 4) ................................................................... 82

23 Decomposição histórica da variância do erro de previsão para o preço do álcool anidro (Modelo 4)

24 Decomposição histórica da variância do erro de previsão para o preço do açúcar cristal exportado (Modelo 4)

25 Decomposição histórica da variância do erro de previsão para o preço do açúcar cristal empacotado ao produtor (Modelo 4)

26 Decomposição histórica da variância do erro de previsão para o preço do açúcar cristal empacotado ao varejo (Modelo 4) 


\title{
TRANSMISSÃO DE PREÇOS ENTRE PRODUTOS DO SETOR SUCROALCOOLEIRO DO ESTADO DE SÃO PAULO
}

\author{
Autor: Lucilio Rogerio Aparecido Alves \\ Orientador: Profa. Dra. Mirian Rumenos Piedade Bacchi
}

\section{RESUMO}

No começo da década de 1990 deu-se início ao processo de desregulamentação dos preços dos produtos do setor sucroalcooleiro através da liberação de seus preços. Neste contexto, esses preços passaram a ser determinados de acordo com as regras de livre mercado. Desde então, o setor sucroalcooleiro tem passado por profundas transformações num período relativamente curto de tempo. Neste trabalho buscou-se analisar a transmissão de preços entre os mercados dos principais produtos do setor sucroalcooleiro do Estado de São Paulo. Determinou-se a intensidade e a duração em que as oscilações de preços são transmitidas de um nível de mercado para outro e de um produto para outro do mesmo nível de mercado. A análise compreendeu o período de maio de 1998 a junho de 2002. O modelo proposto foi implementado utilizando-se testes de raiz unitária de Dickey-Fuller Aumentado (ADF), de co-integração de Johansen e método de Auto-Regressão Vetorial com Correção de Erro (VEC). Os resultados apontam para as inter-relações contemporâneas entre os preços do açúcar cristal industrial no mercado interno e o recebido pela exportação e entre os preços do açúcar cristal empacotado ao produtor e ao varejo. O preço do álcool anidro, por sua vez, não explica contemporaneamente os preços dos açúcares cristal industrial e exportado. Nas decomposições das variâncias dos erros de previsão, observa-se a quase total independência do preço do açúcar cristal industrial, o relacionamento do álcool anidro 
com o preço do açúcar cristal industrial e com o preço do açúcar cristal empacotado ao produtor. $\mathrm{O}$ preço de exportação mostra-se relativamente independente em relação às variáveis de mercado interno. O preço do açúcar cristal empacotado ao produtor apresenta dependência do preço do açúcar cristal industrial e do preço do açúcar cristal empacotado ao varejo. Para o mercado varejista do açúcar cristal empacotado, a quase totalidade das variações de seus preços são explicadas pela própria variável e pelo preço do mercado produtor. Nas funções de impulso-resposta, os resultados mostram que choque no preço do açúcar cristal industrial causa impacto positivo sobre os preços do álcool anidro e do açúcar cristal empacotado ao produtor com um período de defasagem. Choque no preço do álcool anidro impacta positivamente os preços do açúcar cristal industrial e do cristal exportado apenas no quarto período após o choque. Choque no preço do açúcar cristal exportado, praticamente não causa impacto nos preços de mercado interno. O choque no preço do açúcar cristal empacotado ao produtor tem influência sobre os preços dos açúcares cristal industrial e cristal empacotado ao varejo com um período de defasagem e sobre o preço do açúcar cristal exportado no quarto período. Choque no preço do mercado varejista do açúcar cristal empacotado, ao contrário do que se esperava, causa impacto negativo sobre os preços dos açúcares cristal industrial e cristal empacotado ao produtor. Em termos gerais, os resultados apontam para inter-relações entre os preços dos produtos analisados, uma vez que choque em quaisquer das variáveis tem impacto na mesma direção sobre as demais, principalmente após um pequeno período de tempo de ajustamento. No entanto, essas relações não apresentaram-se tão expressivas quanto se esperava. 


\title{
PRICE TRANSMISSION AMONG PRODUCTS OF THE SUGAR-ETHANOL SECTOR IN SÃO PAULO STATE
}

\author{
Author: Lucilio Rogerio Aparecido Alves \\ Advisor: Prof. Dr. Mirian Rumenos Piedade Bacchi
}

\section{SUMMARY}

In the early 1990's it was started the price deregulation process of products of sugar-ethanol sector through the exemption of its prices. In this context, these prices started to be determined according to regulations of a free market. Since then, the sugarethanol sector has undergone profound changes in a considerably short period of time. This study aims to analyze price transmission among markets of main products of the sugar-ethanol sector in São Paulo State. It was determined the intensity and the duration in which price fluctuations are transmitted from a level of market to another and from one product to another of the same level. The analysis was carried out during the period of May 1998 and June 2002. The proposed model was implemented by making use of tests for unit root of Augmented Dickey-Fulley (ADF), of co-integration of Johansen and the method of Vector Auto-Regression with Error Correction (VEC). Results point to contemporary inter-relations among industrial crystal sugar prices in the domestic market and the market derived from exportation and among the prices of packed crystal sugar to producer and to retailing. The anhydrous ethanol price does not explain contemporarily the prices of industrial crystal and exported sugar. In the decomposition of forecast errors variance, it is noted the almost entire independence of the industrial crystal sugar price, the relating of anhydrous ethanol price to the industrial crystal sugar price and to the packed crystal sugar price to producer. The prices for exportation remain 
relatively independent from the variances of the domestic market. The price of packed crystal sugar to producer reveals dependency to the price of industrial crystal sugar and to packed crystal sugar to retailing. To the retail market the packed crystal sugar, almost all of its price variations are explained by the variable itself and by the producer's operating market price. In the impulse-response functions, results show that shocks to the industrial crystal sugar price causes a positive impact to the prices of anhydrous ethanol and of packed crystal sugar to producer with a time gap. Shocks to the anhydrous ethanol price causes a positive impact to the prices of industrial crystal sugar and to the exported crystal sugar only in fourth period after the shock. Shocks to exported crystal sugar price, basically does not cause any impact to the domestic market. The shock to the packed crystal sugar to producer has influence on the prices of industrial crystal and packed crystal sugar to retailing with a time gap and on the exported crystal sugar price in the fourth period. The shock to the packed crystal sugar price in the retail market causes a negative impact to the price of industrial crystal and packed sugar to producer. In general terms, results point to inter-relations among the prices of the products studied, once shocks to any of the variables lead to impacts in the direction to the others, specially after a short adjusting time. However, these relations did not reveal as expressive as expected. 


\section{INTRODUÇÃO}

\subsection{Considerações gerais}

Este trabalho tem como objetivo analisar as inter-relações entre os níveis de mercado dos principais produtos do setor sucroalcooleiro do Estado de São Paulo quanto à formação e transmissão de preços. O período sob análise compreende maio de 1998 a junho de 2002.

A agroindústria canavieira brasileira teve seu desenvolvimento marcado por grande intervenção governamental. Foram poucos os períodos da história nacional em que isso não ocorreu - apenas durante o Império e nas primeiras décadas do regime republicano. Sua prática intensa ocorreu durante o período colonial, acentuando-se após a Revolução de 30, entretanto, esmoreceu-se no começo dos anos 90.

No começo da década de 1990 deu-se início ao processo de desregulamentação dos preços dos produtos do setor sucroalcooleiro através da liberação do preço do açúcar, a qual estendeu-se para o preço do álcool anidro e depois para os preços da cana e do álcool hidratado. Neste contexto, esses preços passaram a ser determinados de acordo com as regras de livre mercado. Desde então, o setor sucroalcooleiro tem passado por profundas transformações num período relativamente curto de tempo.

O desmonte do aparato estatal, que tinha como objetivo o gerenciamento de suas atividades, conduziu o setor à necessidade de realizar adequações, em um contexto de livre mercado. As mudanças mais sensíveis vêm ocorrendo tanto na forma de conduzir a produção e quanto na comercialização dos seus produtos. Nesse ambiente, não há dúvida que o setor vem amadurecendo, uma vez que as empresas tomam agora suas decisões em função de variáveis de mercado e não mais em função dos preços e subsídios fixados pelo governo. Entende-se que nesse cenário as análises relativas ao 
comportamento dos preços dos produtos sucroalcooleiros podem auxiliar na tomada de decisão dos agentes desse setor.

Um diagnóstico mais apurado do desempenho do setor sucroalcooleiro brasileiro, especificamente no Estado de São Paulo, demanda uma análise detalhada das inter-relações econômicas entre os diversos segmentos produtivos que compõem essa cadeia. O mercado de açúcar mantém estreita relação com o de álcool, com o setor alimentício e com o setor exportador, no qual participa de forma significativa.

Pouco se conhece ainda acerca do comportamento do mercado de açúcar face às oscilações de seus preços interno e externo e de alterações nos preços de álcool combustível. Contudo, há preocupação constante tanto de produtores quanto de agentes de comercialização (atacadistas e varejistas, por exemplo) sobre a forma como a relação entre os preços dos produtos agroindustriais é estabelecida nos diferentes níveis de mercado. Pode-se dizer que a intensidade pela qual um choque de preços impacta os diferentes níveis de mercado constitui-se em informação importante tanto para os agentes de mercado como para os formuladores de política setorial, principalmente num contexto de redução da ingerência governamental no setor.

O mecanismo de formação e determinação de preços e produção opera sob dependência de uma superestrutura institucional, a qual é dada, principalmente, pelo grau de competitividade do mercado e pelo grau de intervenção governamental. É essa superestrutura que condiciona a transmissão de preços do consumidor ao produtor e vice-versa (Barros, 1987).

Assim, a análise do processo de formação e transmissão de preços do setor sucroalcooleiro incorpora duas hipóteses básicas. A primeira trata da existência de relação entre os mercados doméstico e internacional do açúcar, que se tornou mais acentuada nos últimos anos da década de 1990. A segunda diz respeito ao elevado grau de relacionamento dos mercados de açúcar e álcool.

As análises supracitadas restringem-se ao setor sucroalcooleiro do Estado de São Paulo tendo em vista que esse estado é responsável pelo maior volume de produção nacional de açúcar e de álcool. Na safra 2000/01 a produção paulista de açúcar e de álcool representou aproximadamente $63 \%$ da produção nacional desses produtos. 


\subsection{Objetivos}

Neste trabalho analisam-se as inter-relações entre os preços dos produtos do setor sucroalcooleiro do Estado de São Paulo. Especificamente, pretende-se determinar a intensidade e a duração que oscilações de preços são transmitidas de um nível de mercado para outro e de um produto para outro do mesmo nível de mercado.

\subsection{Estrutura do trabalho}

Além desse capítulo introdutório, este trabalho consta de mais quatro. No segundo é apresentado uma revisão de literatura enfocando alguns aspectos da evolução do setor sucroalcooleiro nacional e características da comercialização desses produtos. Também são discutidos alguns trabalhos relacionados à comercialização e formação de preços de produtos agropecuários. Posteriormente, no capítulo três, é discutido o modelo econômico considerado na análise e os procedimentos econométricos a serem aplicados. Os resultados são apresentados no quarto capítulo e as conclusões no último capítulo. 


\section{REVISÃO DE LITERATURA}

\subsection{Evolução do complexo agroindustrial canavieiro no Brasil}

O complexo agroindustrial canavieiro constitui-se na mais antiga atividade econômica do Brasil. Diante disso, este subcapítulo tem como objetivo chamar a atenção para aspectos que permitam a compreensão de sua trajetória e de suas características estruturais. Discussão da importância da cana-de-açúcar na história econômica do país pode ser encontrada em trabalhos como: Simonsen (1969), Furtado (1974), Prado Júnior (1981) e Baer (1996); bem como naqueles que tratam especificamente do setor: Azevedo (1958), Queda (1972), Szmrecsányi (1979), Bray (1989), Shikida (1998), Ramos (1999), Moraes (2000), Bray et al. (2000) e Soares (2000) entre outros.

Em termos gerais, segundo Ramos \& Belik (1989), o açúcar nordestino foi o carro-chefe da agroindústria canavieira brasileira durante quatro séculos, sempre se destacando por sua produção e volume exportado. Esse destaque deveu-se às condições edafoclimáticas favoráveis e à maior proximidade geográfica dos mercados europeus, comparativamente à região Centro-Sul do país. A partir de meados do século XVIII, inicia-se a produção de açúcar e aguardente no Centro-Sul, especificamente em São Paulo, Rio de Janeiro e Minas Gerais, mas apenas em meados do século XIX o açúcar dessa região passou a ter destaque na produção nacional. Mesmo assim, não conseguia concorrer no mercado externo devido à baixa qualidade, comparativamente ao açúcar nordestino.

Até o início do século $\mathrm{XX}$, a região Centro-Sul mantinha oligopsônio na comercialização do açúcar nordestino e oligopólio na comercialização de açúcar refinado. Em contraste, o Nordeste, além das pressões dos importadores do Centro-Sul, 
sofria com a concorrência da produção açucareira das Antilhas e da Europa, no mercado internacional (Ramos \& Belik, 1989).

O aumento da produção de açúcar na região Centro-Sul, principalmente no Estado de São Paulo, ocorreu simultaneamente a uma redução da demanda externa, resultante da crise mundial dos anos 30 . Em contrapartida, aumentou a pressão dos produtores nordestinos para a criação de um mecanismo que thes garantisse controle de preços e quantidade. Segundo Carvalho et al. (1993, p.161),

"A crise de 1929 incumbiu-se de manifestar (...) os conflitos que vinham sendo gestados no interior do complexo agroindustrial canavieiro. Em função da necessidade de conciliar (...) os vários interesses dos produtores de açúcar, dos plantadores de cana, dos comerciantes e dos consumidores, criou-se em 1931 a Comissão de Defesa da Produção Açucareira (CDPA), iniciando a intervenção governamental no setor".

É nesse ambiente que a intervenção governamental do Estado intensifica-se a partir do início dos anos 30, buscando administrar os conflitos que foram surgindo no interior da agroindústria canavieira (Belik et al., 1998). O marco fundamental da intervenção estatal foi a criação do Instituto do Açúcar e do Álcool (IAA) em 1933, tendo como principais objetivos resolver o problema de superprodução da agroindústria canavieira através do planejamento e do controle anual da produção, adequando-os às necessidades de consumo interno e externo, além de fomentar a fabricação de álcool anidro no país (Szmrecsányi, 1979). Segundo esse autor (p.180), 'tratava-se, em outras palavras, de promover o reerguimento da indústria açucareira e de dar solução ao problema do álcool-combustível". Para atingir suas finalidades, o IAA estabeleceu um sistema rígido de quotas, que eram distribuídas entre as diferentes unidades produtoras.

Por ocasião da II Guerra Mundial, o transporte marítimo utilizado nas exportações e importações do Brasil, assim como no comércio de produtos por cabotagem (utilizado em grande intensidade no mercado interno entre o Norte e o Sul do país), tornou-se de grande risco. Essa dificuldade afetou a comercialização do açúcar, cujo abastecimento interno dependia fundamentalmente da produção nordestina, sendo que os principais centros consumidores estavam localizados no Centro-Sul do país 
(Szmrecsányi \& Moreira, 1991). A demanda insatisfeita dos principais centros consumidores criou condições favoráveis para que as usinas do Centro-Sul reivindicassem o aumento da produção. A solicitação foi aceita e essa expansão deu origem à definitiva transferência do eixo da produção canavieira e açucareira para a região Centro-Sul do país, principalmente para os estados do Sudeste; a concretização dessa transferência ocorre somente na década de 50. Esse fato encerrou um período de mais de quatrocentos anos de hegemonia produtiva da região Nordeste, que foi o berço para o desenvolvimento da produção açucareira no Brasil (Machado, 2002).

A intervenção estatal, ao se estender ao longo das décadas seguintes, passou a ser parte da própria história do complexo e a determinar a sua estrutura. Pode-se destacar como principais mecanismos dessa intervenção: os preços administrados, entrada de novas unidades industriais e produção sob controle estatal (principalmente através de quotas de produção), garantia de mercado e subsídios, divisão regional dos mercados (Centro-Sul, Norte-Nordeste), controle da exportação e restrições ao capital estrangeiro (Ramos, 1999b).

Para regular as relações entre usineiros e fornecedores, foi instituído em 1941 o Estatuto da Lavoura Canavieira. Da mesma forma, no início da década de 70, instaurouse uma política de concentração e modernização deste complexo agroindustrial. Neste intuito, vários programas foram criados, dentre eles o Programa Nacional de Melhoramento da Cana-de-açúcar - Planalsucar (1966) e posto em funcionamento na safra 1971/72, o Programa de Racionalização da Agroindústria Açucareira (1971), que foi substituído pelo Programa de Apoio à Agroindústria Açucareira (1973) e, em seguida, pelo Programa Nacional do Álcool - Proálcool ${ }^{1}$, em novembro de 1975.

Até o advento do Proálcool, a moagem da cana era destinada à produção de açúcar. O álcool era um produto residual da destilação do mel pobre, ou seja, era considerado um subproduto da fabricação do açúcar. Até então, existiam apenas destilarias anexas às usinas.

\footnotetext{
${ }^{1}$ Mais informações sobre o Proálcool e a evolução da agroindústria canavieira podem ser encontradas em Szmrecsányi \& Moreira (1991) e em Shikida (1998). Informações sobre a cronologia do desenvolvimento da agroindústria canavieira também podem ser obtidas em Moraes (2000) e em Pinazza \& Alimandro (2000).
} 
Num primeiro momento, entre 1975 e 1979, o Proálcool deu ênfase para o aproveitamento da capacidade ociosa das destilarias anexas às usinas de açúcar préexistentes, com o intuito de aumentar a produção de álcool anidro (a ser adicionado na gasolina). Posteriormente (1980/85), intensificou-se o uso do álcool hidratado como combustível e deu-se prioridade à implantação de destilarias autônomas. A partir de 1986, houve o processo de desaceleração e crise do Proálcool, conforme caracterização feita por Shikida (1998).

Segundo Shikida (1998), as duas primeiras fases do Proálcool conduziram ao fortalecimento de regiões e estados tradicionais nesse segmento produtivo (São Paulo e Rio de Janeiro, na região Sudeste, e Alagoas e Pernambuco, no Nordeste). A produção alcooleira expandiu-se também em regiões que apresentavam razoável infra-estrutura para produção de açúcar (Minas Gerais, Paraná, Paraíba e Rio Grande do Norte) e para estados sem nenhuma tradição sucroalcooleira (Goiás, Mato Grosso e Mato Grosso do $\mathrm{Sul})$.

A partir de 1985, o governo brasileiro passou a executar uma política de controle da inflação. Segundo Nogueira (2000), esse controle estava ancorado na contenção de preços das tarifas públicas, incluindo os preços de combustíveis e, consequentemente, do álcool, assim como os preços do açúcar e da cana-de-açúcar.

O início da década de 1990 é caracterizado por uma conjuntura econômica diferenciada, norteada por políticas que sinalizavam a menor intervenção estatal e, posteriormente, o setor sucroalcooleiro é inserido em um contexto de livre mercado. Em março de 1990 é extinto o IAA.

A partir dessa data, o setor tem passado por profunda transformação. Ainda no início da década de 1990, o preço do açúcar no mercado interno deixou de ser tabelado; as exportações desse produto foram liberadas a partir de 1994; o preço do álcool anidro deixou de ser tabelado em 1997; em 1998 o governo liberou o preço da cana-de-açúcar e em 1999, o preço do álcool hidratado.

Diante disto, as mudanças mais sensíveis vêm ocorrendo na produção e nas formas de comercializar os produtos, uma vez que essas atividades deixaram de ser orientadas pelo governo e passaram a fazer parte da administração privada. Dessa forma, 
as empresas do setor passaram a depender mais de sua eficiência administrativa e econômica, face à concorrência mais intensa na colocação de seus produtos finais, o açúcar e o álcool. Os produtores e agentes de mercado passaram a conduzir suas ações de acordo com os sinais emitidos por preços determinados em mercados competitivos. Esse contexto é reflexo do processo de reestruturação pelo qual passou o setor.

No próximo subcapítulo apresentam-se alguns dados sobre o setor açucareiro no âmbito mundial e nacional e sobre o setor alcooleiro nacional.

\subsection{Aspectos do setor sucroalcooleiro nacional e açucareiro mundial}

A relevância de estudar o funcionamento do setor sucroalcooleiro brasileiro reside em sua grande importância tanto no contexto doméstico como internacional, diferenciando-se dos demais países por produzir, em escala industrial, tanto açúcar como álcool. Em termos de mercado interno, a cana-de-açúcar ocupa posição de destaque entre as principais culturas quanto à área plantada e também quanto ao volume e valor da produção. Atualmente, o mercado sucroalcooleiro movimenta cerca de $\mathrm{R} \$ 12,7$ bilhões por ano, com faturamentos diretos e indiretos, que correspondem a aproximadamente 2,3\% do PIB brasileiro. Na safra 2000/01 foram produzidas 255 milhões de toneladas de cana, que resultaram em um total de 16,2 milhões de toneladas de açúcar e 10,6 milhões de $\mathrm{m}^{3}$ de álcool. O parque sucroalcooleiro nacional possui mais de 300 unidades industriais em atividade, sendo que cerca de $41 \%$ localizam-se no Estado de São Paulo. Aproximadamente $27 \%$ são destilarias autônomas e o restante, usinas com destilaria anexa (JornalCana, 2002).

Os principais estados produtores de cana-de-açúcar do Brasil, considerando a média da produção do país das safras 1999/00 e 2000/01, são: São Paulo (60,4\%), Alagoas (8,0\%), Paraná (7,7\%) e Minas Gerais (4,3\%). No geral, o setor sucroalcooleiro do Estado de São Paulo aparece como o mais dinâmico do país. 


\subsubsection{O setor açucareiro nacional e mundial}

O açúcar produzido mundialmente advém da cana-de-açúcar e da beterraba, diferindo apenas no processo de produção. Do volume total mundialmente produzido na safra 2000/01, aproximadamente $30 \%$ foram oriundos da beterraba e $70 \%$ da cana-deaçúcar (dados da safra 2000/01) (Schouchana \& Widonsck, 2001). A safra mundial compreende ao período de setembro de um ano a outubro do ano seguinte.

O Brasil destaca-se como o maior produtor e exportador mundial de açúcar, sendo um dos países mais competitivos nesse mercado. Na safra 2000/01, a produção e exportação brasileiras representaram 12,4\% e 18,9\%, respectivamente, do total mundial (Tabela 1). Da safra 1992/93 à 2000/01, a produção mundial cresceu à taxa geométrica de 2,2\% a.a. e a brasileira à taxa de 7,9\% a.a.. Quanto à exportação, o comércio mundial teve uma ampliação à taxa de 2,5\% a.a., sendo que as exportações brasileiras aumentaram 14,9\% a.a.. No período que compreende os anos-safra 1992/93 a 2000/01, as exportações brasileiras representaram em média $40 \%$ do total produzido no país.

Conforme se pode verificar na Tabela 1, o ano-safra de 1999/00 correspondeu ao de maior produção mundial de açúcar e maior comércio internacional, fato atribuído ao aumento do volume produzido e exportado pelo Brasil. De acordo com dados da safra 2000/01, o Brasil é o principal produtor mundial seguido pela Índia, União Européia, China, Estados Unidos da América (EUA), Tailândia, México, Austrália e Cuba, dentre

outros (United States Department of Agriculture - USDA, 2001). Por outro lado, além do Brasil, os principais exportadores de açúcar são os países que compõem a União Européia no conjunto, a Tailândia, a Austrália e Cuba.

Os dados da Tabela 2 mostram que o Brasil exportou, em média, 5,4 milhões de toneladas por ano no período de 1989 a 2001. A receita anual média obtida com as exportações brasileiras de açúcar foi de US\$ 1,245 bilhão, com um preço médio de US\$ 256,30/t. A quantidade exportada cresceu à taxa de 21,2\% a.a. e a receita total, à $17 \%$ a.a.. De acordo com os dados divulgados pela Associação de Produtores de Álcool e Açúcar do Estado do Paraná - Alcopar (2002), a participação da receita de exportação 
de açúcar na receita total de exportações brasileiras apresentou uma média de 3\% nos últimos anos.

Tabela 1. Evolução da quantidade produzida e exportada de açúcar pelo mundo e pelo Brasil, 1992/93 a 2000/01 (milhares de toneladas métricas).

\begin{tabular}{|c|c|c|c|c|c|c|}
\hline \multirow{2}{*}{$\begin{array}{c}\text { ANO- } \\
\text { SAFRA }\end{array}$} & \multicolumn{3}{|c|}{ PRODUÇĀO } & \multicolumn{3}{|c|}{ EXPORTAÇÃO } \\
\hline & MUNDO (A) & BRASIL (B) & $(\mathrm{A}) /(\mathrm{B})$ & MUNDO (C) & BRASIL (D) & $(\mathrm{C}) /(\mathrm{D})$ \\
\hline 1992/93 & 112.099 & 9.800 & $8,7 \%$ & 28.937 & 2.425 & $8,4 \%$ \\
\hline 1993/94 & 109.731 & 9.930 & $9,0 \%$ & 29.849 & 2.861 & $9,6 \%$ \\
\hline 1994/95 & 115.920 & 12.500 & $10,8 \%$ & 30.289 & 4.300 & $14,2 \%$ \\
\hline $1995 / 96$ & 122.229 & 13.700 & $10,4 \%$ & 34.219 & 5.800 & $17,0 \%$ \\
\hline 1996/97 & 122.546 & 14.650 & $11,2 \%$ & 35.816 & 5.800 & $16,2 \%$ \\
\hline $1997 / 98$ & 124.939 & 15.700 & $12,6 \%$ & 35.426 & 7.200 & $20,3 \%$ \\
\hline $1998 / 99$ & 130.425 & 18.300 & $13,8 \%$ & 35.944 & 8.750 & $24,3 \%$ \\
\hline 1999/00 & 134.528 & 20.100 & $14,0 \%$ & 39.257 & 11.300 & $28,8 \%$ \\
\hline 2000/01 & 124.472 & 15.400 & $12,4 \%$ & 32.822 & 6.200 & $18,9 \%$ \\
\hline Tx. de cresc. & $2,2 \%$ & $7,9 \%$ & - & $2,5 \%$ & $14,9 \%$ & - \\
\hline
\end{tabular}

Fonte: USDA (2001)

Segundo Veiga Filho (2001), pode-se creditar o crescimento das exportações brasileira de açúcar a motivos de origens interna e externa. No cenário internacional, considera-se o fim do acordo bilateral da União das Repúblicas Socialistas Soviéticas e Cuba (URSS-Cuba), que possibilitou ao Brasil ocupar parte do mercado de Cuba no comércio de açúcar com os países da antiga URSS. No âmbito interno, cita-se a crescente participação das exportações oriundas de São Paulo, respaldadas pelo custo de produção mais baixo do Brasil e do mundo.

Para Moraes (2000), ao analisar as possíveis causas da elevação das exportações brasileira, principalmente na década de 1990, é preciso levar em consideração os problemas de falta de crédito e de liquidez enfrentados pelos produtores durante essa década. Através das exportações os produtores encontraram uma forma de financiar a produção e aumentar sua liquidez através da antecipação de recursos feita pelos Adiantamentos sobre os Contratos de Câmbio (ACC).

Segundo Schouchana \& Widonsck (2001), as exportações brasileiras de açúcar destinam-se a 69 países e, dentre eles, a Rússia é atualmente o maior importador. Também merecem destaques como importadores de açúcar brasileiro o Egito, a Nigéria, o Irã, os Emirados Árabes, o Canadá, a Índia, a Romênia, os EUA e a Arábia Saudita. 
Tabela 2. Quantidade, valor e preço de exportação de açúcar brasileiro, 1989 a 2001.

\begin{tabular}{cccc}
\hline ANO & VOLUME $(\mathrm{t})$ & $\begin{array}{c}\text { RECEITA } \\
(\mathrm{US} \$ \text { FOB })\end{array}$ & $\begin{array}{c}\text { PREÇO MEDIO } \\
(\mathrm{US} \$ / \mathrm{t})\end{array}$ \\
\hline 1989 & 1.052 .819 & 305.508 .138 & 290,18 \\
1990 & 1.540 .536 & 440.302 .868 & 341,11 \\
1991 & 1.655 .112 & 440.302 .868 & 266,03 \\
1992 & 2.410 .963 & 598.472 .261 & 248,23 \\
1993 & 3.029 .831 & 778.941 .851 & 257,09 \\
1994 & 3.432 .541 & 991.469 .680 & 268,84 \\
1995 & 6.632 .624 & 1.918 .198 .177 & 307,47 \\
1996 & 5.420 .630 & 1.611 .494 .186 & 297,29 \\
1997 & 6.377 .481 & 1.771 .323 .690 & 277,75 \\
1998 & 8.372 .602 & 1.940 .836 .750 & 231,61 \\
1999 & 12.124 .224 & 1.909 .746 .379 & 157,51 \\
2000 & 6.506 .359 & 1.199 .110 .875 & 184,30 \\
2001 & 11.173 .214 & 2.279 .058 .288 & 203,98 \\
Taxa de crescimento & $21,2 \%$ & $17 \%$ & $-3,9 \%$ \\
\hline
\end{tabular}

Fonte: Alcopar (2002)

Considerando a safra 2000/01, a maior produção e consumo de açúcar ocorreram na Ásia. Essa região é importadora líquida de açúcar e seu expressivo consumo deve-se ao grande contingente populacional. Em seguida, vem a América do Sul, com produção bastante superior ao consumo, tornando-se uma das principais regiões exportadoras do mundo. As Américas Central e do Norte e o Oeste Europeu também têm uma expressiva produção de açúcar, mas seus consumos internos absorvem cerca de $85 \%$ da produção. O consumo da União Européia representa aproximadamente $80 \%$ de sua produção interna, mas, mesmo assim, ela tem uma representação expressiva em termos de exportação. O continente africano, por sua vez, produz em torno de $80 \%$ de seu consumo interno e o Leste Europeu, 52\% aproximadamente, sendo o restante obtido através de importações. Por fim, a Oceania, uma das regiões que menos produz açúcar no mundo, consome cerca de $31 \%$ de sua produção (F.O.Licht's, 2001).

Os maiores importadores mundiais de açúcar, entre as safras 1995/96 e 2000/01, foram: Rússia (média de 4,5 milhões t/safra), EUA (1,9 milhão t/safra), União Européia (1,8 milhão t/safra), Japão (1,6 milhão t/safra), Coréia (1,5 milhão t/safra), Indonésia (1,4 milhão t/safra), Malásia (1,2 milhão t/safra), Irã (1,1 milhão t/safra) e Canadá (1,1 milhão t/safra), dentre outros (USDA, 2001). 
No âmbito nacional, o setor sucroalcooleiro pode ser dividido em duas regiões bastante distintas, quais sejam: Norte-Nordeste (safra de setembro a março) e Centro$\mathrm{Sul}^{2}$ (safra de maio a dezembro), cujas vocações, estratégias e níveis de produtividade são diferentes. Dado que os períodos de safra entre as duas regiões são diferentes, isto faz com que o Brasil seja abastecido com açúcar e álcool o ano todo. Segundo Moraes (2000), o açúcar é o principal produto do setor sucroalcooleiro da região Norte-Nordeste e, até a safra 1991/92, a região Centro-Sul estava voltada à produção de álcool, sendo que, desde então, houve acréscimos da produção de açúcar.

Em termos de crescimento, entre as safras 1988/89 e 2000/01, a produção de açúcar da região Norte-Nordeste cresceu à taxa de $0,7 \%$ a.a., enquanto que na região Centro-Sul o crescimento foi de $13,1 \%$ a.a., resultando em uma expansão nacional de 9,6\% a.a. (Alcopar, 2002). Em termos de parcela de produção de açúcar, considerando a média das safras 1999/00 e 2000/01, a região Centro-Sul produziu aproximadamente $82,5 \%$ do total nacional. O estado que mais se destaca nessa produção é São Paulo, com representação média de cerca de $63,5 \%$ da produção nacional.

Ao analisar os custos de produção do açúcar, o Estado de São Paulo e a região Centro-Sul, na qual esse estado está inserido, apresentam os menores valores do mundo: US\$ 190/t e US\$ 240/t, respectivamente. Na região Norte-Nordeste, o custo foi estimado em US\$ 300/t. Em relação aos demais países produtores do mundo, a África do Sul possui um custo de US\$ 250/t, Austrália de US\$ 270/t, Tailândia de US\$ 310/t, Argentina de US\$ 364/t, União Européia de US\$ 480/t e os EUA de US\$ 525/t (Stalder \& Burnquist, 1997). Segundo Schouchana \& Widonsck (2001), o custo de produção de açúcar na Índia é de US\$ 280/t, no México de US\$ 308/t, na Rússia de US\$ 430/t, na China de US\$ 500/t e na Itália de US\$ 770/t.

A seguir, descreve-se brevemente o mercado de álcool combustível brasileiro, que começou a ser incentivado em 1975, em meio à crise de petróleo.

\footnotetext{
2 A região Norte-Nordeste é composta pelos seguintes estados: Alagoas, Bahia, Ceará, Maranhão, Pará, Paraíba, Pernambuco, Piauí, Rio Grande do Norte, Sergipe e Tocantins. A região Centro-Sul, por São Paulo, Paraná, Minas Gerais, Mato Grosso, Mato Grosso do Sul, Goiás, Rio de Janeiro, Espírito Santo, Rio Grande do Sul e Santa Catarina.
} 


\subsubsection{O setor alcooleiro nacional}

Atualmente, o Brasil é o maior produtor de álcool do mundo. Desde o início do Proálcool, o álcool hidratado apresentou acréscimos de produção até a safra 1991/92 e decréscimos nas safras seguintes (Tabela 3). O álcool anidro, por sua vez, teve oscilações de produção, com tendência de aumento, principalmente na década de 90 . O aumento do volume produzido de álcool absorveu, consequentemente, uma maior parcela da cana-de-açúcar. Do ano-safra de 1970/71 a 2000/01, a produção de álcool anidro apresentou um crescimento de 9,4\% a.a., a de álcool hidratado cresceu à taxa de 15,7\% a.a., enquanto que a produção total de álcool aumentou, em média, 12,9\% a.a..

O álcool anidro vinha sendo produzido em menor volume que o álcool hidratado, posição essa que se inverteu no ano-safra 2000/01, conforme pode ser visualizado na Tabela 3. Esse comportamento está associado ao aumento do consumo da mistura álcool/gasolina e à queda no consumo de álcool hidratado em função do sucateamento da frota existente e do inexpressivo aumento das vendas de veículos novos movidos a álcool. Vale ressaltar que o consumo brasileiro de gasolina vem aumentando significativamente ao longo do tempo, com taxa de crescimento acentuada na segunda metade da década de 90 .

Considerando as safras 1999/00 e 2000/01, a região Centro-Sul e o Estado de São Paulo produziram aproximadamente $87,5 \%$ e $63 \%$, respectivamente, do álcool total nacional. A região Centro-Sul e o Estado de São Paulo produziram 86,7\% e 62,6\%, respectivamente, do total nacional de álcool anidro e 88,3\% e 63,2\%, respectivamente, do total nacional de álcool hidratado (UDOP, 2002).

O álcool produzido no país é quase que integralmente absorvido no mercado interno. Segundo Marjotta-Maistro (2002), entre os anos de 1995 e 2001 as exportações de álcool representaram entre $0,23 \%$ e $0,16 \%$ do valor das exportações brasileiras, destinando-se a países como o Japão, Coréia do Sul, Jamaica e Filipinas. Por outro lado, a importância do álcool como combustível no mercado interno brasileiro faz com que, em alguns momentos, ocorra a importação desse produto, como aconteceu no final do ano de 2000 e início de 2001. 
Tabela 3. Evolução da produção de álcool no Brasil e percentual de cana-de-açúcar convertida em açúcar, de 1970/71 a 2000/01.

\begin{tabular}{|c|c|c|c|c|}
\hline \multirow[b]{2}{*}{ Safra } & \multicolumn{3}{|c|}{ Álcool } & \multirow{2}{*}{$\begin{array}{l}\text { \% cana } \\
\text { convertida } \\
\text { em açúcar }\end{array}$} \\
\hline & $\begin{array}{c}\text { Anidro } \\
\left(1000 \mathrm{~m}^{3}\right)\end{array}$ & $\begin{array}{l}\text { Hidratado } \\
\left(1000 \mathrm{~m}^{3}\right)\end{array}$ & $\begin{array}{c}\text { Total } \\
\left(1000 \mathrm{~m}^{3}\right)\end{array}$ & \\
\hline $1970 / 71$ & 252 & 385 & 637 & $82,22 \%$ \\
\hline $1971 / 72$ & 390 & 223 & 613 & $82,69 \%$ \\
\hline $1972 / 73$ & 389 & 292 & 681 & $83,40 \%$ \\
\hline $1973 / 74$ & 306 & 260 & 566 & $87,22 \%$ \\
\hline $1974 / 75$ & 217 & 409 & 625 & $86,15 \%$ \\
\hline $1975 / 76$ & 233 & 323 & 556 & $86,28 \%$ \\
\hline $1976 / 77$ & 300 & 364 & 664 & $85,69 \%$ \\
\hline $1977 / 78$ & 1.777 & 293 & 1.470 & $76,39 \%$ \\
\hline $1978 / 79$ & 2.096 & 395 & 2.491 & $63,19 \%$ \\
\hline $1979 / 80$ & 2.712 & 671 & 3.384 & $54,16 \%$ \\
\hline $1980 / 81$ & 2.104 & 1.602 & 3.706 & $55,01 \%$ \\
\hline $1981 / 82$ & 1.413 & 2.750 & 4.163 & $52,54 \%$ \\
\hline $1982 / 83$ & 3.550 & 2.274 & 5.823 & $46,69 \%$ \\
\hline $1983 / 84$ & 2.469 & 5.392 & 7.861 & $40,26 \%$ \\
\hline $1984 / 85$ & 2.102 & 7.150 & 9.252 & $35,88 \%$ \\
\hline $1985 / 86$ & 3.208 & 8.612 & 11.820 & $27,87 \%$ \\
\hline $1986 / 87$ & 2.168 & 8.338 & 10.506 & $31,25 \%$ \\
\hline $1987 / 88$ & 1.983 & 9.474 & 11.457 & $29,00 \%$ \\
\hline $1988 / 89$ & 1.726 & 9.978 & 11.704 & $28,80 \%$ \\
\hline $1989 / 90$ & 1.341 & 10.557 & 11.898 & $26,50 \%$ \\
\hline 1990/91 & 1.309 & 10.474 & 11.783 & $28,86 \%$ \\
\hline $1991 / 92$ & 1.984 & 10.768 & 12.752 & $28,50 \%$ \\
\hline $1992 / 93$ & 2.216 & 9.470 & 11.687 & $31,68 \%$ \\
\hline $1993 / 94$ & 2.523 & 8.774 & 11.296 & $32,57 \%$ \\
\hline $1994 / 95$ & 2.867 & 9.825 & 12.692 & $35,03 \%$ \\
\hline $1995 / 96$ & 3.040 & 9.631 & 12.671 & $37,92 \%$ \\
\hline $1996 / 97$ & 4.600 & 9.634 & 14.234 & $35,55 \%$ \\
\hline $1997 / 98$ & 5.689 & 9.720 & 15.408 & $35,92 \%$ \\
\hline 1998/99 & 5.692 & 8.236 & 13.928 & $42.83 \%$ \\
\hline 1999/00 & 6.134 & 6.934 & 13.069 & $46.23 \%$ \\
\hline $2000 / 01$ & 5.536 & 4.905 & 10.441 & $45,36 \%$ \\
\hline Taxa de cresc. & $9,4 \%$ & $15,7 \%$ & $12,9 \%$ & - \\
\hline
\end{tabular}

Fonte: Usinas e Destilarias do Oeste Paulista - UDOP (2002)

\subsubsection{Comercialização do açúcar e do álcool nacionais}

Uma das mais importantes características do setor sucroalcooleiro brasileiro consiste na flexibilidade de sua produção. As usinas de açúcar com destilaria anexa podem direcionar o caldo oriundo da moagem da cana-de-açúcar tanto para a fabricação 
de açúcar como para de álcool (Figura 1), dependendo da rentabilidade desses produtos. Segundo Marjotta-Maistro (2002), no processo de tomada de decisão os agentes formam expectativa considerando preços e quantidades demandadas de açúcar e álcool, tanto no mercado interno como no externo.

As fábricas do setor sucroalcooleiro podem produzir os alcoóis anidro e hidratado, os quais são absorvidos quase que totalmente pelo mercado interno, conforme já citado. Já o açúcar pode ser comercializado nos mercados interno e externo, conforme as vantagens comparativas de preços. O bagaço da cana, obtido após a moagem, pode ser utilizado no processo de co-geração de energia ou como matéria-prima para a produção de celulose. Outros subprodutos comumente aproveitados ao longo do processo são a vinhaça (fertilizante) e o melaço (fermentações).

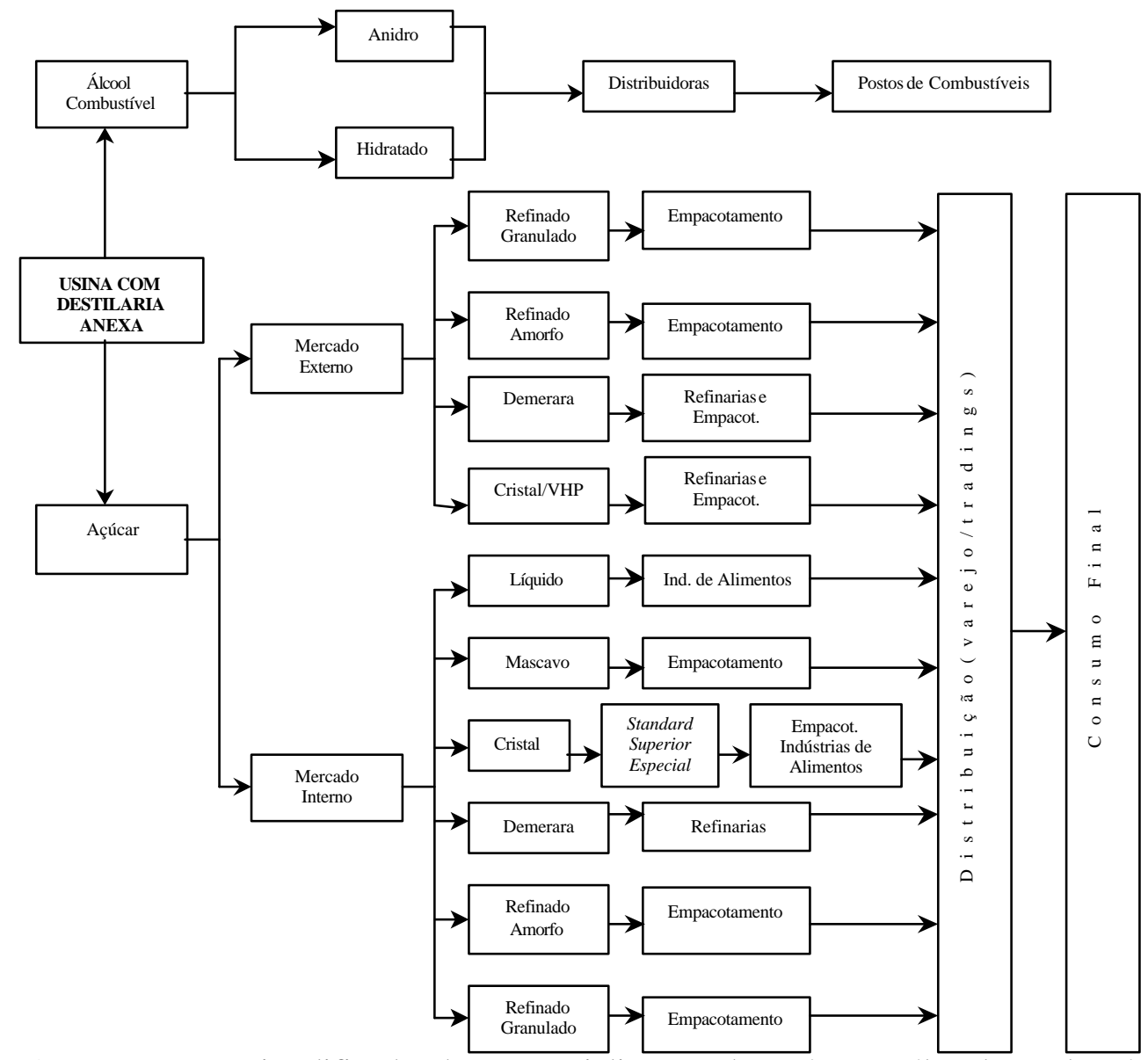

Figura 1 - Esquema simplificado da comercialização de açúcar e álcool combustível no Brasil.

Fonte: Elaborado pelo autor 
O álcool hidratado é utilizado como combustível para a frota de carros movidos exclusivamente a álcool e o álcool anidro na mistura com a gasolina A para compor a gasolina C. A proporção de álcool anidro na gasolina vem alterando-se ao longo do tempo, uma vez que a definição do percentual depende da expectativa da produção de álcool e/ou da disponibilidade do mesmo, objetivando a estabilidade do preço (MarjottaMaistro, 2002). Até 1992, a proporção de álcool anidro na gasolina era de 14\%, passando para 22\% até 1998; nesse ano a proporção alterou-se para 24\%; em 2000, voltou a ser de 20\%; a partir de maio de 2001, 22\%; e, a partir de janeiro de 2002, a proporção passou a ser de $24 \%$, alterando-se novamente no segundo semestre desse ano para $25 \%$.

Segundo Marjotta-Maistro (2002), o álcool hidratado para fins combustíveis é adquirido pelas distribuidoras e direcionado para os postos de revenda, que totalizavam cerca de 29 mil no início de 2002, considerando todas as regiões do país. A maior concentração desses postos está na região Sudeste. Segundo Moraes (2002), a demanda pelo álcool hidratado depende de seu preço em relação à gasolina, uma vez que os consumidores são extremamente sensíveis ao diferencial de preços entre esses dois produtos, podendo migrar de um para outro, impactando a demanda do álcool. Em relação à produção, "preços maiores desse produto direcionam a cana para a produção de álcool, sendo que, em sentido inverso, aumenta-se a produção de açúcar em detrimento da produção de álcool" (Moraes, 2002, p.29).

No mercado açucareiro, os principais tipos de açúcar comercializados são o demerara (ou bruto), o cristal, o refinado, o mascavo e o líquido (Figura 1). O açúcar demerara é destinado à exportação e dá origem ao açúcar refinado (granulado e amorfo), voltado, quase totalmente, ao consumo final. $\mathrm{O}$ açúcar cristal classifica-se de acordo com o teor de sacarose, umidade, presença de cinzas e cor. A partir desses critérios, são obtidos o açúcar cristal standard de menor qualidade (comercializado no mercado doméstico), o açúcar cristal superior de qualidade intermediária (também comercializado no mercado interno) e o açúcar cristal especial, considerado de melhor qualidade (comercializado interna e externamente). O critério usado para classificação do açúcar pela cor é o ICUMSA, que se refere ao valor numérico da cor de uma solução açucarada 
medido pelo método da International Commision for Uniform Methods of Sugar Analysis (ICUMSA).

No mercado interno predominam o açúcar refinado e o cristal empacotado, quando se considera o consumo final das famílias. $\mathrm{O}$ primeiro é mais consumido nas regiões Sul e Sudeste do país e o segundo na região Central e Norte/Nordeste. O setor industrial utiliza com maior intensidade o açúcar cristal e, em pequena proporção, o refinado.

Em termos de mercado interno, a maior parte do açúcar cristal consumido domesticamente é empacotada pelas próprias usinas, conduzindo a um decréscimo na participação das empacotadoras independentes nesse mercado. Esse fato ocorre devido à necessidade das unidades produtoras de açúcar vender um produto com maior valor agregado, na busca de maior rentabilidade. Da mesma forma, com o interesse por agregação de valor praticamente todo o açúcar refinado comercializado no mercado interno é refinado na própria usina ou em empresas a ela ligadas.

Os principais clientes das usinas no mercado interno são $0^{3}$ :

- as indústrias que usam, principalmente, o açúcar cristal "standard" e o "superior". Esse segmento é caracterizado pelos industriais e empacotadores do Norte e Nordeste, produtores de doces caseiros, indústrias de refrigerantes de segunda linha e algumas vinícolas. Para essas indústrias, o fator mais importante é o preço;

- o segmento composto pelas indústrias de achocolatados, bolachas, compotas e doces usam, na maior parte das vezes, o açúcar cristal "especial". Para eles, os fatores mais importantes são o preço e a garantia de suprimento;

- outro segmento que se preocupa com os fatores de qualidade e garantia de suprimento é aquele formado pelas indústrias de misturas secas, balas, laticínios, chocolates brancos e refrigerantes de primeira linha. Essas indústrias usam, mais frequientemente, o açúcar cristal "especial extra".

As transações entre usinas e indústrias no mercado interno se dão tanto através de intermediários (corretores) como diretamente entre as unidades produtoras e os

\footnotetext{
${ }^{3}$ Essas análises estão baseadas em Neves et al. (1998).
} 
compradores. Os intermediários são os representantes das usinas, exclusivos ou não, que recebem uma "comissão" paga por essas unidades para cada venda efetuada ${ }^{4}$. No caso das cooperativas, as negociações são feitas quase que exclusivamente de forma direta. As transações externas, por sua vez, ocorrem através de contratos de venda, na maioria das vezes vinculados a um contrato de mercado futuro internacional.

Ressalta-se que, a partir de 1995, passaram a ser comercializados os Contratos Futuros e de Opções de Açúcar na Bolsa de Mercadorias e Futuros (BM\&F) - São Paulo/Brasil, que têm como referência o açúcar cristal especial, cor 150, cotado em US\$/sc de 50kg. Vale lembrar também o lançamento pela BM\&F, no ano de 2000, de um Contrato Futuro para o Álcool Anidro. Esses contratos tiveram o intuito de auxiliar produtores, consumidores, distribuidoras, refinadoras e mesmo exportadores de açúcar a se prevenirem contra riscos de preços num contexto econômico em que a variabilidade desse item é acentuada, ao que geralmente se associa uma maior volatilidade das receitas.

No mercado externo, as principais Bolsas que negociam Contratos Futuros de Açúcar são a London International Financial Futures and Options Exchange (LIFFE), em Londres, e a Coffee, Sugar and Cocoa Exchange (CSCE), em Nova York/EUA. A LIFFE tem como referência o açúcar refinado granulado, cotados em US $\$ /$ t, sendo que o Brasil tem como referência esse contrato para a fixação do preço de exportação de açúcar cristal 100 e 150. A CSCE, por sua vez, negocia o açúcar demerara, cotado em US\$(cents)/libra-peso, onde o Brasil fixa o preço de exportação de açúcar tipo Very Hight Polarization (VHP).

No tocante à oferta do produto, a de açúcar é caracterizada pela presença de grandes grupos. Entretanto, a maior parte do açúcar é comercializada por unidades independentes. O consumo de açúcar, por sua vez, tanto cristal como refinado, é pouco concentrado em comparação ao mercado vendedor. Da mesma forma, o mercado varejista de açúcar cristal e refinado é pulverizado, sendo constituído desde pequenos armazéns até hipermercados.

\footnotetext{
${ }^{4}$ Em Neves et al. (1998), são discutidas as vantagens e desvantagens da usina em ter intermediários na comercialização de açúcar.
} 
Segundo Carvalho, L. (2000), o açúcar tem sua demanda interna crescendo à taxa de 1,7\% a.a. (de meados dos anos 80 a final dos anos 90); o consumo direto guarda relação com o crescimento populacional, com a renda da população e com a existência e procura de produtos substitutos, e o industrial com o crescimento do Produto Interno Bruto (PIB). A distribuição do volume consumido no país é, em grandes números, 61,5\% uso direto e 38,5\% consumo industrial (Tabela 4). Segundo Silva \& Ramos (1998), o Brasil já apresenta elevado consumo per capita - enquanto a média mundial está ao redor de $20 \mathrm{~kg} /$ pessoa, no Brasil tem-se algo próximo a $50 \mathrm{~kg} /$ pessoa. Entre os fatores que contribuíram para o acréscimo no consumo, citam-se o crescimento populacional e a melhor distribuição de renda, que permitiram aos consumidores o acesso a uma gama de produtos industrializados nos quais o açúcar é empregado, tais como balas, refrigerantes, chocolates etc. (Schouchana \& Widonsck, 2001).

Tabela 4. Distribuição do consumo de açúcar no Brasil.

\begin{tabular}{lcc}
\hline \multicolumn{1}{c}{ Descrição do uso } & $1000 \mathrm{t}$ & $\%$ \\
\hline 1. Uso direto (mesa) & 5.100 & 61,45 \\
Refinado amorfo & 1.700 & \\
Outros & 3.400 & 38,55 \\
2. Industrial & 3.200 & \\
Refrigerantes & 1.216 & \\
Doces/geléias/confeitos & 629 & \\
Outros (chocolates, biscoitos, sorvetes etc.) & 1.355 & 100,00 \\
Total do Brasil & 8.300 & \\
\hline
\end{tabular}

Fonte: Carvalho, L. (2000, p.41)

Conforme Carvalho, C. (2000), com a desregulamentação do setor, as empresas produtoras de açúcar estão alterando as estratégias competitivas visando à diferenciação produtiva, ao aprofundamento e especialização na produção de açúcar e álcool bem como à diferenciação de produtos. Com a diferenciação de produtos, as empresas estão buscando agregar valor às mercadorias.

Segundo Belik et al., 1998, até os anos 80, apenas duas marcas de açúcar refinado dominavam o mercado no Brasil. Do início dos anos 90 em diante, as empresas passaram a investir em refinarias próprias e intensificaram a diferenciação de produtos 
pela qualidade, marca, preço, entrega, embalagem e diferentes tipos de refino, entre outros atributos.

Esses autores discutem alguns casos que ocorreram no Centro-Sul do país onde usinas lançaram suas marcas próprias, em vários tamanhos de embalagens e diferentes tipos de refino, assim como passaram a acrescentar vitaminas no açúcar para o consumo infantil. Outrossim, investiram na produção de açúcar líquido invertido, com o objetivo de atender ao consumo industrial e prestar um serviço às empresas que necessitam desse produto na produção de alimentos e bebidas.

Segundo Shikida (1999), devem ser considerados também os efeitos do processo de concorrência e complementariedade impostos pelos sucedâneos do açúcar. Dentre eles, citam-se: o xarope de milho (High Fructose Corn Syrup - HFCS), stévia, sacarina, ciclamato, aspartame, acesulfame de potássio, talina, anidridos de frutose e esteviosídio. A crescente demanda por substitutos do açúcar está relacionada com a alimentação de pessoas diabéticas e/ou interessadas em dietas menos calóricas, com o objetivo de diminuir o acúmulo de glicose no sangue, evitar a elevação do peso corporal e formação de cáries, entre outros. Esse autor enfatiza que a concorrência dos adoçantes com o açúcar não se limita apenas à substituição simples desse último produto pelo primeiro no consumo das famílias, mas também à sua utilização nas indústrias de bebidas dietéticas, especialmente de refrigerantes e de alimentos ${ }^{5}$.

\subsubsection{Análise dos preços do açúcar e do álcool}

Primeiramente deve-se enfatizar que, apesar da concentração existente no setor sucroalcooleiro, desde a liberalização dos preços no mercado de açúcar esses têm se formado de acordo com as características de mercados concorrenciais. Assim, os fatores determinantes desses preços estão relacionados à oferta e à demanda do produto, tanto no âmbito doméstico como internacional. Dentre os fatores deslocadores da demanda e

\footnotetext{
${ }^{5}$ Outras informações sobre os produtos concorrentes ou substitutos do açúcar podem sem encontradas em Silva \& Ramos (1998) e em Szmrecsányi (1989).
} 
oferta de açúcar, podem ser citados a renda interna, o crescimento vegetativo da população, o uso de substitutos, a taxa de câmbio, a renda externa, o preço no mercado internacional, o preço de produtos alternativos na lavoura e na indústria (álcool), fatores climáticos e os custos de produção (Burnquist et al., 2002).

Ao analisar os níveis de preços ao produtor, observa-se pela Figura 2 que o açúcar cristal destinado à indústria apresenta, como era de se esperar, um preço inferior aos demais. ${ }^{6}$ Adicionando os serviços de empacotamento, os produtores passam a receber mais pelo produto (linha intermediária na Figura 2). Por outro lado, o açúcar refinado, por ter um custo de produção maior, é vendido a preço superior.

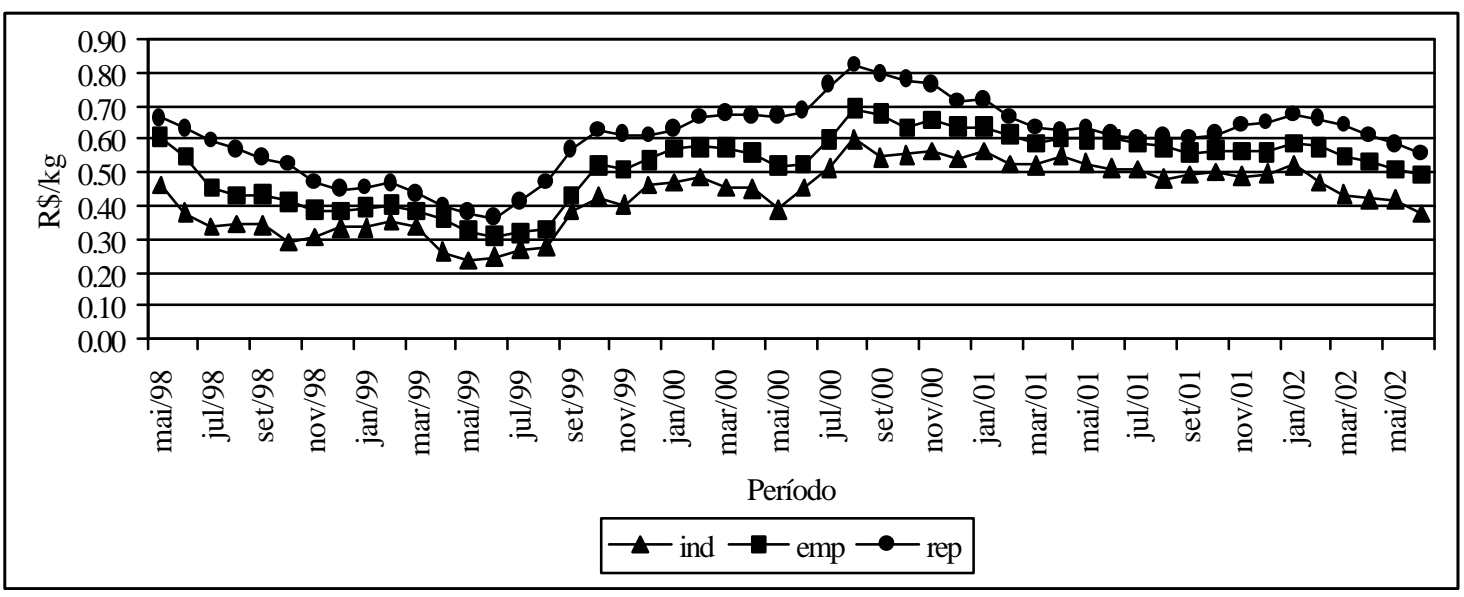

Figura 2 - Evolução dos preços do açúcar cristal industrial (ind), cristal empacotado ao produtor (emp) e refinado ao produtor (rep), de maio/1998 a jun./2002.

Fonte: Centro de Estudos Avançados em Economia Aplicada - CEPEA (2002)

Comparando os preços que os produtores obtêm vendendo seus produtos no mercado interno ou no externo, fica evidente o pequeno grau de relacionamento entre os preços desses mercados em alguns períodos (Figura 3). ${ }^{7}$ Ao analisar os preços do açúcar cristal empacotado e do açúcar refinado ao varejo, observa-se, como esperado, um valor

\footnotetext{
${ }^{6}$ Todos os preços a serem analisados estão deflacionados pelo Índice Geral de Preços - Disponibilidade Interna (IGP-DI), da Fundação Getúlio Vargas (FGV), base: junho de $2002=100$.

${ }^{7} \mathrm{O}$ preço de mercado externo considerado refere-se ao valor do primeiro vencimento desta Bolsa.
} 
superior do açúcar refinado, da mesma maneira que ocorre no nível do produtor (Figura $4)^{8}$.

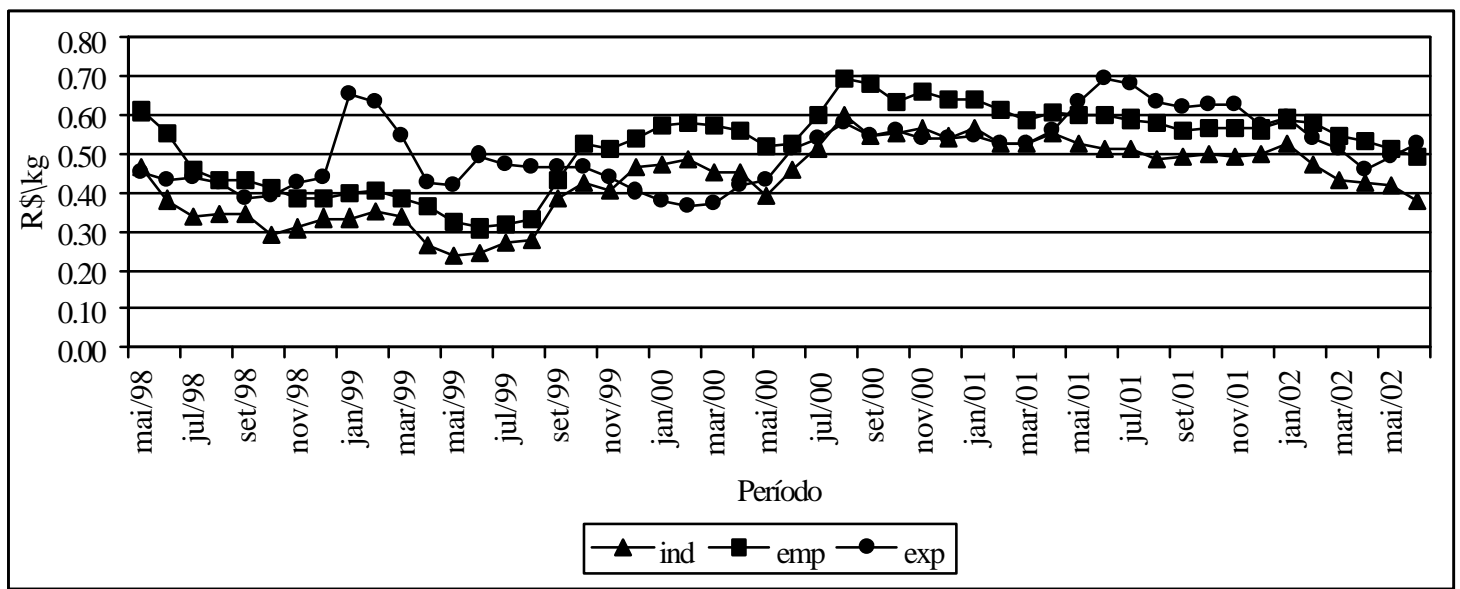

Figura 3 - Evolução dos preços do açúcar no mercado interno ao produtor (ind e emp) e externo (exp), de maio/1998 a jun./2002.

Fonte: CEPEA (2002)

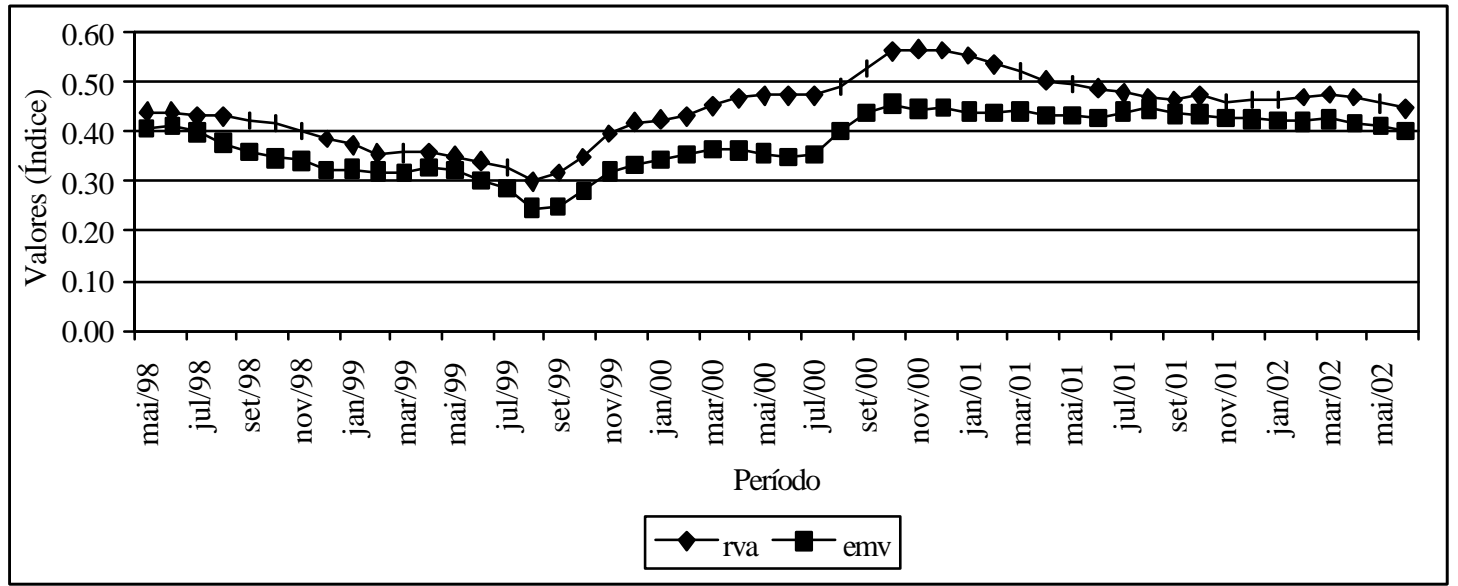

Figura 4 - Evolução dos preços dos açúcares cristal empacotado (emv) e refinado (rva), ao varejo, maio/1998 a abr./2002.

Fonte: Instituto Brasileiro de Geografia e Estatística - IBGE (2002)

Na Figura 5 pode ser analisada a evolução dos preços do álcool anidro e do álcool hidratado combustível, para o período de dados disponíveis no CEPEA (2002). E,

${ }^{8}$ Esses dados referem-se ao Índice Nacional de Preços ao Consumidor (INPC), elaborado pelo IBGE (2002). 
na Figura 6 consta a evolução dos preços do açúcar cristal industrial e do álcool anidro expressos em Reais por quilo de Açúcar Total Recuperável (ATR), onde se observa que o preço do açúcar apresenta patamar mais elevado para todo o período, motivando o aumento da produção de açúcar nos últimos anos.

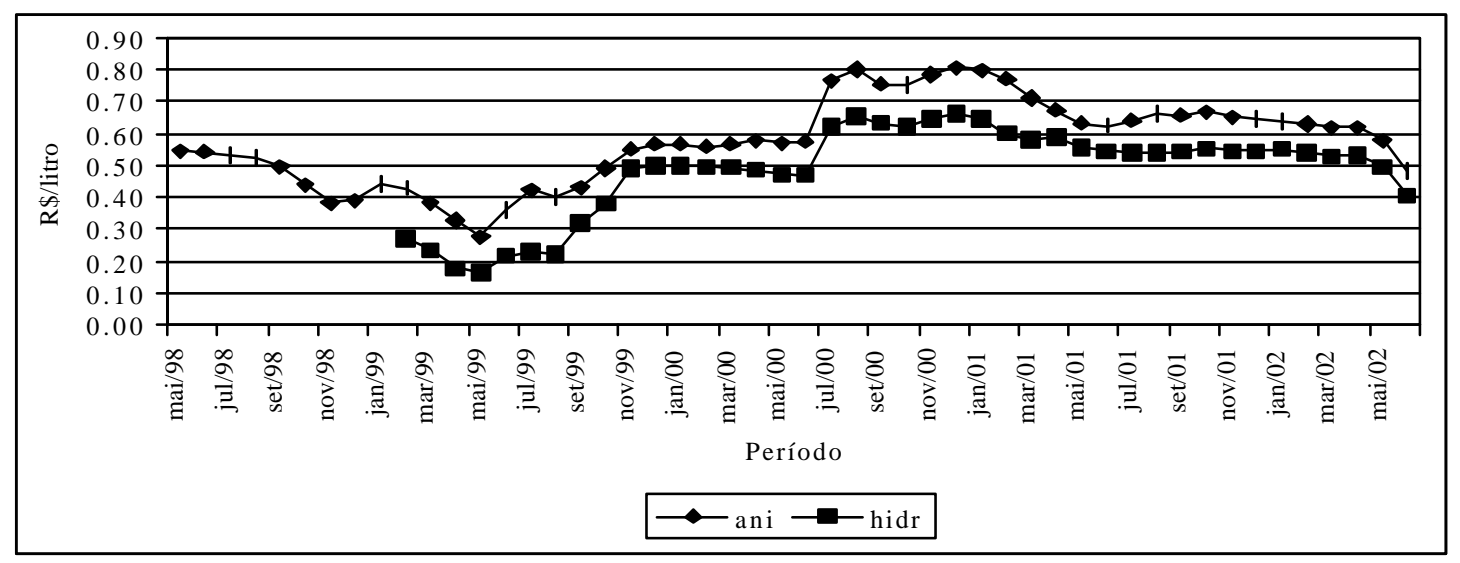

Figura 5 - Evolução dos preços dos alcoóis anidro (ani) e hidratado (hidr), ao produtor, maio/1998 a jun./2002.

Fonte: CEPEA (2002)

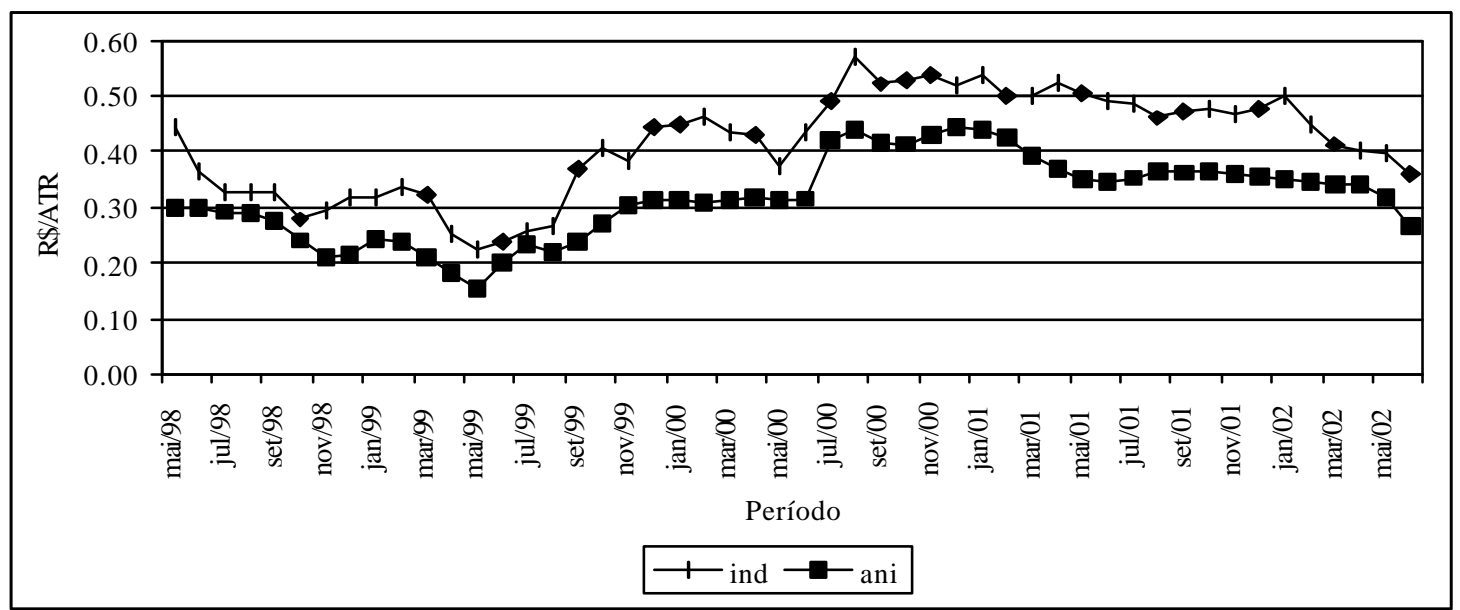

Figura 6 - Evolução dos preços do álcool anidro (ani) e do açúcar cristal industrial (ind) em termos de R \$ATR, maio/1998 a jun./2002.

Fonte: CEPEA (2002)

Para visualizar melhor as alterações de preços, no ANEXO A apresenta-se a evolução dos preços relativos entre os produtos supracitados. No próximo subcapítulo 
serão descritos alguns trabalhos que tiveram como objetivo a análise da comercialização de açúcar e outros produtos agropecuários.

\subsection{Trabalhos voltados à análise do comportamento de preços e comercialização de produtos agropecuários}

A princípio, não há muitos trabalhos enfocando especificamente o comportamento dos preços e comercialização no setor sucroalcooleiro brasileiro. Isso é facilmente explicado pela intervenção governamental no setor que definia desde o planejamento da produção de cana-de-açúcar até a produção e comercialização dos produtos industrializados.

Um dos primeiros trabalhos que analisou a estrutura do mercado de açúcar foi elaborado por Barros (1975), especificando e quantificando os parâmetros estruturais das funções de oferta total, demanda interna, demanda de exportação e relação de estoques, utilizando-se do modelo de Nerlove, dos Métodos dos Mínimos Quadrados Ordinários (MQO) e de Dois Estágios (Theil-Bassman). Esse autor constatou que produtores de açúcar são poucos sensíveis às variações de preços no curto prazo. Da mesma forma, os consumidores brasileiros apresentam pouca variação no consumo dadas alterações no preço e na renda monetária. A demanda de exportação apresentou-se elástica, no curto e longo prazos, e a demanda por estocagem mostrou-se inelástica no curto prazo, mas sensivelmente elástica no longo prazo.

Stalder \& Burnquist (1996), utilizando-se de fórmulas análogas às apresentadas em Barros (1987), analisaram o comportamento das margens de comercialização do açúcar e do álcool na usina/destilaria em relação ao produtor de cana-de-açúcar. De acordo com os resultados encontrados por essas autoras, as margens de comercialização do açúcar e do álcool mantiveram-se praticamente constantes no período de 1980 a 1994, no patamar de $40 \%$ e $50 \%$, respectivamente.

Stalder (1997) analisou o padrão das exportações brasileiras de açúcar entre 1979 e 1994, utilizando-se do modelo de Market-Share Constante e do modelo de 
Elasticidade de Substituição no comércio internacional. Na análise de Market-Share Constante, verificou que o Brasil perdeu participação no mercado mundial num primeiro momento, vindo a recuperar no período seguinte. Os coeficientes de Elasticidade de Substituição indicaram substituibilidade entre o açúcar exportado pelo Brasil e o exportado pela África do Sul (açúcar total e bruto), França (bruto), Filipinas (refinado) e Alemanha (refinado). Identificou-se, também, a existência de diferenciação entre o açúcar brasileiro em relação ao das Filipinas (açúcar total) e ao da Austrália (refinado) pelo mercado importador.

Com o objetivo específico de analisar o consumo industrial de açúcar no Estado de São Paulo, buscando identificar alguns aspectos relativos ao comportamento dos agentes de mercado no que se refere ao processo de comercialização do açúcar, Marjotta-Maistro (1998) aplicou questionários ${ }^{9}$ às empresas alimentícias do estado. Essa autora utilizou como metodologia um modelo de comportamento e de estratégias básicas de comercialização para o mercado industrial. Seus resultados foram explorados tendo como base as características do mercado de consumo industrial, as tendências do mercado e o aumento da concorrência.

Bacchi \& Marjotta-Maistro (1999) decompuseram o preço médio mensal do açúcar cristal em saca praticado no Estado de São Paulo em seus componentes sazonais e de tendência. A partir disso, fizeram uma análise da relação do preço do açúcar cristal em saca com o preço do açúcar refinado e empacotado, no período de abril de 1997 a outubro de 1999. Observaram que o preço do açúcar cristal empacotado manteve-se, em média, $23 \%$ acima do preço de venda da saca de $50 \mathrm{~kg}$, apresentando comportamento sazonal semelhante a este.

Lima \& Sampaio (1999) analisaram o impacto da variação dos preços internacionais na formação dos preços domésticos utilizando um modelo de defasagem distribuída com um termo auto-regressivo. A série utilizada na análise refere-se ao período de 1981 a 1995. Os autores tiveram como resultado que os preços do mercado internacional pouco afetavam os preços no mercado interno no período analisado. Dessa

\footnotetext{
${ }^{9}$ Entre os meses de setembro e novembro de 1996 foram enviados 224 questionários, obtendo um retorno de $22,3 \%$ do total enviado.
} 
forma, as variações observadas no preço do mercado internacional não se transmitiam integralmente para o mercado brasileiro, pois, segundo os autores, eram amortizadas pelas políticas de preços existentes no setor sucroalcooleiro nacional. Concluíram, também, que a memória auto-regressiva da série possibilitava, em grande parte, a determinação do preço vigente no mercado interno de açúcar.

Esses resultados foram reforçados por outro trabalho, no qual Lima \& Sampaio (1999b) estudaram as fontes de formação dos preços no mercado doméstico utilizando uma função transferência (modelo ARMAX), com o intuito de verificar o impacto dos preços do açúcar do mercado internacional na formação dos preços domésticos. Os resultados mostraram que os preços domésticos são mais influenciados pela memória auto-regressiva do que pelos preços do mercado internacional.

Costa (2000) analisou o comportamento dos preços do açúcar (no período de abril de 1997 a maio de 2000) e do álcool (de maio de 1998 a julho de 2000) no mercado do Estado de São Paulo. Como resultado, obteve que a formação dos preços desses produtos pode ser expressa por relações de desequilíbrios no curto prazo, sendo que choques de oferta e demanda causam alterações iniciais nos preços ao produtor e ao atacado simultaneamente.

Com o intuito de analisar as relações estruturais do mercado de açúcar no Estado de São Paulo, Caruso \& Burnquist (2001) estimaram equações de oferta e demanda de açúcar pelo método dos Mínimos Quadrados Ordinários. Os resultados mostraram que a oferta de açúcar é elástica em relação ao preço do produto no mercado interno e ao preço do álcool. A demanda de açúcar é inelástica a preço e renda, sugerindo ser o açúcar um bem essencial.

Caruso (2002) estimou uma equação de oferta e demanda de açúcar para o Estado de São Paulo usando um sistema de equações simultâneas. Como os resultados encontrados não foram satisfatórios, a autora estimou uma equação de demanda de açúcar no Estado de São Paulo. Nessa estimativa, os resultados foram satisfatórios e mostraram que a demanda é inelástica a preço e renda.

Bacchi et al. (2002) estimaram uma função de oferta de exportação brasileira de açúcar utilizando a metodologia de Auto-Regressão Vetorial (VAR) com identificação 
pelo processo de Bernanke, fundamentando-se em um modelo teórico com pressuposto de que as exportações são excedente do mercado interno. Obtiveram como resultado que aumento no preço de exportação e desvalorização cambial causam aumento nas exportações, enquanto aumento no preço doméstico ou na renda interna causam decréscimo nas exportações. As variáveis de mercado interno causaram maiores impactos sobre as exportações que as de mercado externo.

Por fim, pode-se citar o trabalho desenvolvido por Burnquist et al. (2002), no qual foi analisado o processo de comercialização dos produtos do setor sucroalcooleiro brasileiro. Nesse contexto, os autores fizeram uma análise dos preços relativos e composição da produção do setor, assim como da estrutura e concentração do mercado de açúcar e álcool e do sistema de remuneração de cana desenvolvido para o Estado de São Paulo. Diante das mudanças verificadas na comercialização dos produtos em período recente, concluiu-se que o setor respondeu de forma relativamente rápida e eficiente, mas que o processo de adequações mantém-se em desenvolvimento.

Contudo, existem vários trabalhos cujo objetivo foi analisar o comportamento dos preços de produtos brasileiros, principalmente agrícolas. Na maioria dos casos, esses trabalhos adotaram como metodologia os modelos propostos por Granger (1969), Sims (1972), Gardner (1975), Heien (1980), Barros (1990) e o Método de Auto-Regressão Vetorial (VAR), proposto por Sims (1980). A seguir são descritos alguns desses estudos.

Entre os trabalhos que usaram o modelo desenvolvido por Sims (1972), cita-se Carvalho et al. (1983), que testaram a causalidade entre preços interno e externo do mercado de algodão, entre os diversos níveis de comercialização. Burnquist (1986) analisou a causalidade de preços em diferentes níveis de mercados agrícolas (considerou os produtos feijão, cebola e batata). Bacchi (1995) estimou a causalidade entre preços no mercado de carnes do Estado de São Paulo. Almeida \& Mesquita (1995), por sua vez, usaram esse modelo para estimar causalidade entre preço externo e quantidade exportada de café do Brasil. Zen (1997) utilizou teste de causalidade para estimar as relações existentes entre os preços de boi gordo nas diversas praças do Estado de São Paulo e regiões do Triângulo Mineiro, Goiás e do Mato Grosso do Sul, bem como entre os preços do boi e da carne bovina ao atacado. Felippi \& Waquil (1999) estudaram a 
transmissão de preços da batata inglesa entre os níveis dos mercados atacadista e varejista na região Metropolitana de Porto Alegre. Santos \& Fett (1999) estimaram as elasticidades da transmissão de preços entre os três níveis de mercado da maçã (produtor, atacado e varejo). Os métodos de causalidade e transmissão de preços também foram utilizados por Mafioletti \& Barros (2000), na análise do processo de formação de preço da soja no Brasil, tanto entre os níveis de mercado quanto entre as principais regiões produtoras.

O modelo de Gardner (1975) foi a base teórica para a análise das margens de comercialização e obtenção da demanda derivada da indústria de esmagamento da soja, no trabalho elaborado por Neves (1993). Em termos de mercado interno, Marques (1986) estudou as margens de comercialização e elasticidade de transmissão de preços no mercado de frango. Alves (1996) efetuou análise semelhante para a comercialização de abacaxi, banana e laranja em Minas Gerais.

Utilizando-se das definiçõos de Granger (1969), as margens de comercialização e causalidade de preços agrícolas foram estudadas por Martines Filho (1988). Baseandose no modelo de Heien (1980), Barros (1990) apresentou e testou um modelo teórico de transmissão de preços entre os níveis de produtor, atacado e varejo.

O método de Auto-Regressão Vetorial (VAR) foi adotado por Bliska (1989) para estudar a transmissão de preços no mercado de carne bovina. Esse mercado também foi estudado por Guimarães (1990), usando o método VAR, enfatizando a formação e transmissão de preços. Esta autora baseou-se nos modelos apresentados em Gardner (1975) e Heien (1980). Para analisar a formação de preços na indústria brasileira de soja, Aguiar (1990) baseou-se também nos três modelos supracitados. O método VAR foi utilizado por Bittencourt (1995) com o objetivo de determinar as relações de preços do mercado de frango dos principais estados produtores. Para analisar o impacto dinâmico do risco de preço e dos custos de comercialização de arroz e feijão no Estado de São Paulo, Aguiar \& Barros (1995) utilizaram os multiplicadores de Theil e os modelos VAR. Bacchi (1999) utilizou o método VAR para analisar a transmissão de preços entre os três segmentos da cadeia produtiva da pecuária de corte brasileira (cria, recria e 
engorda). Câmara et al. (2000) utilizaram também essa metodologia para estimar a formação de preços da soja no Brasil no período de novembro de 1995 a abril de 1998.

Outras metodologias foram utilizadas para obter as relações de preços entre mercados, bem como analisar o processo de transmissão de preços. Para analisar a transmissão de preços internacionais de suco de laranja para preços ao produtor de laranja no Estado de São Paulo, Margarido (1994) usou modelos de função de transferência do tipo proposto por Box \& Jenkins (1976). Utilizando este modelo na forma univariada e função de transferência, Bacchi \& Hoffmann (1995) obtiveram previsões de preços de bovino e frango no Estado de São Paulo.

Aguiar (1995), por sua vez, propôs uma adaptação ao modelo de MundlakLarson para análise da transmissão de preços entre os mercados externo e interno no Brasil. Margarido (2000) analisou os efeitos que choques em variáveis macroeconômicas externas e domésticas têm sobre o comportamento do índice de relação de troca entre o setor agrícola e industrial no Brasil. Com este intuito, utilizou-se dos testes de Dickey-Fuller Aumentado, de Phillips-Perron, de co-integração de Johansen e modelo de Auto-Regressão Vetorial com Correção de Erro (VEC). Esses mesmos procedimentos foram utilizados por Freitas et al. (2001) para analisar a transmissão de preços do Porto de Rotterdam para os preços de exportação do farelo de soja no Brasil, Estados Unidos e Argentina. Os testes de Dickey-Fuller Aumentado e de co-integração foram efetuados por Ferreira (2001) na análise da comercialização do feijão no Brasil. Com o objetivo de analisar o perfil de algumas séries econômicas brasileiras no período de janeiro de 1990 a dezembro de 1998, Margarido (2001) utilizou os testes de raiz unitária com quebra estrutural.

Como observado, os modelos de Gardner (1975), Heien (1980) e Barros (1990), são os que mais foram utilizados para análises do processo de formação de preços de produtos do setor agroindustrial. No próximo capítulo, esses trabalhos serão detalhados e também será apresentado o modelo econômico proposto para estudo da formação de preços no setor sucroalcooleiro brasileiro. 


\section{REFERENCIAL METODOLÓGICO E MODELOS ECONÔMICOS}

Este capítulo está dividido em três subcapítulos. No primeiro, descrevem-se brevemente os modelos de Gardner (1975), Heien (1980) e Barros (1990). Em seguida, é proposto o modelo econômico para estudo do processo de formação dos preços no setor sucroalcooleiro nacional. No último subcapítulo são apresentados os métodos econométricos a serem usados para alcançar os objetivos previamente estabelecidos, assim como os dados a serem utilizados e sua origem.

\subsection{Modelos econômicos}

\subsubsection{Modelo de Gardner (1975)}

O modelo de Gardner representa um agregado de firmas que comercializam um produto final produzido através da utilização de uma matéria-prima agrícola à qual são adicionadas atividades para atendimento da demanda pelo produto final (representado por um agregado de atividades de comercialização). Dessa forma, o autor examina as consequiências do equilíbrio competitivo nos mercados da matéria-prima agrícola e do agregado de insumos de comercialização, considerando os níveis de produtor e varejo.

Representando por $a$ a matéria-prima agrícola e por $b$ o insumo de comercialização para a produção do bem final vendido no varejo $(x)$, o modelo pode ser representado pelo seguinte sistema de equações:

$$
x=f(a, b)
$$


$x=D\left(P_{x}, N\right)$

$P_{b}=P_{x} f_{b} \quad$ sendo $\quad \frac{\partial x}{\partial b}=f_{b}$

$P_{a}=P_{x} f_{a} \quad$ sendo $\quad \frac{\partial x}{\partial a}=f_{a}$

$P_{b}=g(b, T)$

$P_{a}=h(a, W)$

onde a equação:

- (1) representa a função de produção do agregado de firmas, a qual Gardner pressupõe possuir retornos constantes à escala;

- (2) representa a função de demanda do bem final, sendo $P_{x}$ o preço ao varejo e $N$ uma variável exógena representando um deslocador da demanda primária;

- (3) e (4) representam as igualdades do preço do insumo ao seu valor do produto marginal, condição necessária para maximização do lucro das firmas;

- (5) e (6) representam as ofertas dos dois insumos considerados, sendo $T$ e $W$ variáveis exógenas, representando deslocadores da oferta de insumo de comercialização e da oferta de matéria-prima, respectivamente.

O modelo mostra o comportamento dos mercados diante de alterações nas variáveis exógenas $(N, W$ e $T)$ e os impactos na relação de preços $P_{x} / P_{a}$. Nota-se que essa relação associa-se diretamente à margem relativa de comercialização $\left[\left(P_{x}-P_{a}\right) / P_{x}\right]$. Essas análises são de natureza estático comparativa. ${ }^{10}$

Considerando equilíbrio nos três níveis de mercado $(x, a$ e $b)$, Gardner mostra que:

a) eventos que aumentam a demanda ao varejo reduzirão a margem relativa de comercialização, desde que a oferta de insumos de comercialização seja mais elástica que a oferta de matéria-prima agrícola, como se espera, já que insumos de mercado têm mais usos alternativos;

${ }^{10}$ Em Barros (1987) tem-se uma abordagem gráfica destas variações. 
b) eventos que aumentam a oferta dos insumos de comercialização causarão decréscimos na margem de comercialização;

c) eventos que alteram a oferta de matéria-prima agrícola causarão alterações no mesmo sentido na margem de comercialização;

d) se a margem de comercialização aumentar, a parcela do produtor rural irá reduzir se a elasticidade de substituição de $a$ por $b$ for menor que um e irá aumentar se a elasticidade for maior que um; e

e) a demanda de produtos agrícolas será, em geral, menos elástica ao produtor do que ao varejo.

\subsubsection{Modelo de Heien (1980)}

Heien desenvolveu um modelo teórico de determinação de preços e margens pressupondo equilíbrio instantâneo entre oferta e demanda nos níveis de varejo, de atacado e de produtor. Entre as diferenças relacionadas ao modelo anterior, têm-se: pressupõe que o equilíbrio só ocorre no longo prazo (para períodos de tempo considerados curtos, ocorrem desequilíbrios nestes mercados); especifica equações de ajustamento de preços seguindo o comportamento dos excessos de demanda; e exclui o mercado de insumos de comercialização. Dessa forma, este é um modelo dinâmico mais adequado para análises de curto prazo, permitindo determinar o que ocorre entre duas situações de equilíbrio.

Contudo, o modelo de Heien tenta ocupar uma lacuna deixada pelo modelo de Gardner no que se refere à dinâmica do processo de transmissão e formação de preços. Esse autor inclui uma análise que demonstra a trajetória dinâmica percorrida entre um equilíbrio e outro dos mercados produtor, atacadista e varejista.

Para descrever o modelo, representam-se por letras maiúsculas as quantidades, por minúsculas os preços e utilizam-se os subscritos $d$ e $s$ para diferenciar demanda de oferta. Desta forma, no varejo as funções de demanda e oferta são dadas, respectivamente, por: 
$V^{d}=h_{1}(r, y)$

$V^{s}=h_{2}(r, w, z)$

onde:

- $\quad V^{d}$ é a quantidade demandada do varejo;

- $\quad r$ é o preço de varejo;

- $\quad y$ representa os fatores exógenos deslocadores da demanda, como a renda;

- $\quad V^{s}$ a quantidade ofertada;

- $\quad w$ o preço de atacado; e

- $z$ representa fatores exógenos, deslocadores da oferta, como os serviços de comercialização.

As funções de demanda e oferta no atacado são, respectivamente:

$W^{d}=h_{3}(r, w, z)$

$W^{s}=h_{4}(w, f, x)$

onde:

- $\quad W^{d}$ representa a quantidade demandada do atacado;

- $\quad W^{s}$ a quantidade ofertada pelos atacadistas;

- $f$ o preço ao produtor; e

- $\quad x$ representa outros custos dos atacadistas.

Para o produtor, as funções de demanda e oferta podem ser representadas, respectivamente, por:

$$
\begin{aligned}
& F^{d}=h_{5}(w, f, x) \\
& F^{s}=h_{6}(f)
\end{aligned}
$$

sendo:

- $\quad F^{d}$ a quantidade demandada de produto agrícola; e

- $\quad F^{s}$ a quantidade ofertada de produto agrícola. 
As equações de ajustamento de preços, através de funções de excessos de demanda, são dadas por:

$$
\begin{aligned}
& v=h_{7}\left(V^{d}-V^{s}\right) \\
& w=h_{8}\left(W^{d}-W^{s}\right) \\
& f=h_{9}\left(F^{d}-F^{s}\right)
\end{aligned}
$$

Com a especificação das relações acima, o modelo completa-se, apresentando uma exceção, qual seja: a de que ao varejo torna-se inviável o ajustamento por excesso de demanda. Isso ocorre devido ao grande número de produtos comercializados pelos estabelecimentos varejistas dificultando o acompanhamento do mercado de todos eles, sendo, dessa forma, mais realista considerar que os varejistas aplicariam um markup sobre os preços pagos pelos insumos e/ou matérias-primas, para definir seu preço de venda.

Dessa forma, considerando-se a hipótese de que ao varejo têm-se retornos constantes à escala, as funções de custo total e custo marginal das firmas são dadas por:

$$
\begin{aligned}
& C=h_{10}\left(V^{s}, w, z\right)=h_{10}(w, z) V^{s} \\
& \frac{\partial C}{\partial V^{s}}=h_{10}(w, z)
\end{aligned}
$$

Como em competição perfeita, o preço de mercado é igual à demanda e à receita marginal e no ponto de ótimo igualam-se ao custo marginal, tem-se:

$$
v=h_{10}(w, z)
$$

Entretanto, considerando a análise no curto prazo, é plausível a pressuposição e utilização de proporções fixas de insumos na produção. Desta forma, a função de produção pode ser representada por aquela proposta por Leontief: 
$V=\min \left(\frac{W}{a_{1}}, \frac{Z}{a_{2}}\right)$

onde $V, W$ e $Z$ são quantidades do produto ao varejo, ao atacado e do insumo de comercialização, respectivamente; e $a_{1}$ e $a_{2}$ são coeficientes técnicos de produção. Como conseqüência, tem-se a função custo:

$C=\left(a_{1} w+a_{2} z\right) V$

Então, de (18) tem-se sob competição perfeita:

$v=a_{1} w+a_{2} z$

Contudo, essa análise é adequada apenas para curtos períodos de tempo, uma vez que a função de produção do tipo Leontief pressupõe elasticidade de substituição entre os insumos igual a zero. Dessa forma, a relação expressa pela equação (21) representa uma política de preços ótima para as firmas, sendo o preço de venda fixado com base nos preços dos insumos e matéria-prima. Por outro lado, uma função de produção que resultasse em elasticidade de substituição não nula seria indicada para representar o longo prazo.

Entretanto, Heien analisou a dinâmica de ajustamento apenas através da relação direta entre o mercado produtor e o varejista. $\mathrm{O}$ modelo foi então definido da seguinte forma:

$$
V=\min \left(\frac{F}{a_{1}}, \frac{Z}{a_{2}}\right)
$$

Assim, a equação (21) torna-se: 
$v_{t}=a_{1} f_{t}+a_{2} z_{t}$

A demanda pelo produto agrícola é:

$F_{t}^{d}=a_{1} V_{t}^{s} \quad a_{1}>0$

Quanto à demanda ao varejo, tem-se:

$V_{t}^{d}=\boldsymbol{\alpha}_{0}+\boldsymbol{\alpha}_{1} v_{t} \quad \boldsymbol{\alpha}_{1}<0$

A oferta do produtor é:

$F_{t}^{s}=\gamma_{0}+\gamma_{1} f_{t} \quad \gamma_{1}>0$

O equilíbrio ao produtor é obtido pelo excesso de demanda entre dois períodos:

$f_{t}-f_{t-1}=\beta_{0}\left(F_{t}^{d}-F_{t}^{s}\right) \quad \beta_{0}>0$

Como o preço de varejo é dado por (23), ao varejista só resta determinar a quantidade a ser ofertada. Desde que a firma não pode predizer com certeza a quantidade demandada, uma solução sugerida é a igualdade entre a oferta corrente e demanda do período anterior, ou seja:

$V_{t}^{s}=V_{t-1}^{d}$

De acordo com essa expressão, se ocorrer um incremento na demanda no varejo, no início do período seguinte os estoques serão acrescidos por meio da regra dada pela equação (28), transmitindo-se, posteriormente, para o produtor por meio de 
(24) e os preços de varejo e produtor aumentarão de acordo com (27) e (23). Entretanto, o aumento no preço de varejo leva a decréscimos na demanda ao varejo, fazendo com que haja queda na quantidade ofertada no período seguinte. Esse processo continua até que o mercado se equilibre. Dessa forma, Heien considera que o modelo formado pelas equações (23) a (28) pode dar origem a soluções estáveis.

\subsubsection{Modelo de Barros (1990)}

Este modelo baseia-se fundamentalmente em Heien, mas com algumas características próprias. Barros considera os três níveis de mercado e supõe que o setor atacadista, por trabalhar com volumes maiores de produto, pode assumir o papel de líder nas variações de preços devido aos baixos custos de mudanças de preços e ao maior acesso à informação; leva em conta também que o ajustamento de preço neste mercado ocorre instantaneamente por excesso de demanda.

Para o produtor e varejista, o ajustamento de preços ocorre com defasagens em relação ao atacadista, uma vez que o produtor comercializa pequena quantidade de produto e os varejistas não são especializados. Os preços ao produtor formam-se através de uma política de markup inverso, isto é, considera-se que o preço recebido pelo produtor é igual ao preço no atacado descontado o custo de comercialização desse último segmento de mercado. Essa suposição decorre do menor grau de concentração verificado no setor produtor em relação ao setor atacadista. Os varejistas, por sua vez, adotariam uma política de markup para definição do preço de equilíbrio para o qual o mercado se dirigiria por meio de ajustes parciais.

No desenvolvimento do modelo, Barros seguiu o procedimento de Heien, admitindo que, no curto prazo, as firmas de comercialização, ao varejo e atacado, operariam de acordo com uma função de produção do tipo Leontief, representadas respectivamente por: 
$V=\min \left(\frac{A}{b_{1}}, \frac{Z}{b_{2}}\right)$

$$
A=\min \left(\frac{P}{c_{1}}, \frac{X}{c_{2}}\right)
$$

onde $V, A$ e $P$ são quantidades do produto ao varejo, atacado e produtor, respectivamente; $Z$ e $X$ são quantidades de insumos de comercialização usados pelo varejo e pelo atacado, respectivamente; $b_{1}, b_{2}, c_{1}$ e $c_{2}$ são coeficientes técnicos de produção.

A demanda do varejo $\left(V_{t}^{d}\right)$ é uma função linear do preço ao varejo $\left(v_{t}\right)$ :

$$
V_{t}^{d}=\theta_{0}+\theta_{1} v_{t} \quad \theta_{1}<0
$$

Aplicando-se procedimentos semelhantes ao do modelo de Heien (1980) para se chegar no equilíbrio competitivo, tem-se que o preço-meta estabelecido pelos agentes varejistas pode ser expresso pela seguinte relação:

$$
v_{t}^{*}=b_{1} a_{t}+b_{2} z_{t}
$$

onde $a$ e $z$ são os preços do produto ao atacado e do insumo de comercialização, respectivamente.

O ajustamento de preço ao varejo se processa da seguinte forma:

$$
v_{t}-v_{t-1}=\alpha\left(v_{t}^{*}-v_{t-1}\right) \quad 0<\alpha<1
$$

A demanda do atacado é igual à demanda do varejo do período anterior, ou seja: 
$A_{t}^{d}=b_{1} V_{t-1}^{d}$

A oferta do atacado é dada pela conversão da oferta do produtor:

$$
A_{t}^{s}=\frac{P_{t}^{s}}{c_{1}}
$$

O preço ao atacado se forma por excesso de demanda, podendo-se escrever:

$$
a_{t}-a_{t-1}=\delta\left(A_{t}^{d}-A_{t}^{s}\right) \quad \delta>0
$$

A oferta do produtor é uma função linear do preço recebido $\left(p_{t}\right)$ no período anterior:

$$
P_{t}^{s}=\gamma_{0}+\gamma_{1} p_{t-1} \quad \gamma_{1}>0
$$

O preço-meta ao produtor se forma com base no preço ao atacado, através de um mecanismo de markup inverso. Dessa forma, tem-se:

$$
p_{t}^{*}=\frac{a_{t}-c_{2} x_{t}}{c_{1}}
$$

onde $x_{t}$ é o preço dos insumos de comercialização no atacado.

No curto prazo, o preço ao produtor se ajusta de acordo com a seguinte expressão:

$$
p_{t}-p_{t-1}=\beta\left(p_{t}^{*}-p_{t-1}\right) \quad 0<\beta<1
$$


Após sucessivas substituições algébricas, chegam-se às seguintes equações de transmissão de preços a serem estimadas, para o varejo, atacado e produtor, respectivamente:

$$
\begin{aligned}
& v_{t}=(1-\boldsymbol{\alpha}) v_{t-1}+\boldsymbol{\alpha} b_{1} a_{t}+\boldsymbol{\alpha} b_{2} z_{t} \\
& a_{t}=\delta\left(\boldsymbol{\theta}_{0} b_{1}-\frac{\gamma_{0}}{c_{1}}\right)+\delta b_{1} \boldsymbol{\theta}_{1} v_{t-1}-\frac{\delta \gamma_{1}}{c_{1}} p_{t-1}+a_{t-1} \\
& p_{t}=(1-\beta) p_{t-1}+\frac{\beta}{c_{1}} a_{t}-\beta \frac{c_{2}}{c_{1}} x_{t}
\end{aligned}
$$

Em seguida, descreve-se o modelo econômico a ser utilizado neste trabalho para representar as inter-relações no setor sucroalcooleiro brasileiro.

\subsection{Modelo econômico proposto}

Neste subcapítulo, busca-se descrever graficamente o setor sucroalcooleiro brasileiro, enfatizando os mercados dos açúcares refinado, cristal industrial, cristal exportado e cristal empacotado, e dos alcoóis anidro e hidratado. Com esse intuito, considera-se que há dois níveis de mercado, o segmento produtor e o de varejo, para os açúcares cristal empacotado, cristal para exportação e refinado. No caso do açúcar refinado, a consideração de dois níveis de mercado é coerente, uma vez que as unidades produtoras fazem o processo de refino e, normalmente, vendem diretamente para o segmento varejista. Embora, a princípio, o mercado de açúcar cristal empacotado seja composto pelos segmentos produtores, atacadistas e varejistas, o atacado, constituído pelas empacotadoras independentes, é cada vez menos representativo nesse mercado. A maior parte do açúcar está sendo empacotada pelas próprias usinas e vendida diretamente para o mercado varejista, conforme ressaltado por Costa (2000). Para o açúcar cristal para exportação, considerar-se-á o segmento representado pelos demandantes no mercado externo e o segmento produtor no mercado interno. Entretanto, 
para o segmento de açúcar cristal destinado à indústria tem-se, conforme discutido, apenas o primeiro nível de mercado (produtor), pois a maioria das transações é feita diretamente entre as usinas e as indústrias de alimentos.

Quanto ao mercado de álcool anidro, considera-se também apenas o primeiro nível de mercado (produtor), uma vez que esse produto é utilizado como aditivo na gasolina. No mercado de álcool hidratado, produto utilizado pela população como combustível, consideram-se os níveis de produção e varejo. Apesar de existirem atacadistas nesse mercado, representados pelas distribuidoras, seus custos serão incorporados ao insumo de comercialização utilizado entre a produção e o consumo final. Ressalta-se, entretanto, a indisponibilidade de dados relativos aos valores negociados entre as distribuidoras e os postos de combustíveis.

Nesse sentido, para melhor visualizar o funcionamento do setor sucroalcooleiro e determinar as relações entre os mercados, primeiramente faz-se uma análise gráfica dos mercados de açúcar (refinado, cristal empacotado, cristal industrial e cristal exportado) e álcool (anidro e hidratado), para chegar no equilíbrio do mercado de canade-açúcar, a partir do qual determinam-se os preços e quantidades que vigorarão em cada nível de mercado, para cada produto. Para estas análises considera-se preço equivalente da cana-de-açúcar igual para todos os produtos analisados. ${ }^{11}$ Dessa forma, seria indiferente produzir qualquer dos produtos no que diz respeito ao valor da matériaprima.

Essas relações discutidas estão na Figura 7. No mercado de açúcar refinado, considera-se como dada a demanda ao varejo $\left(D_{R V}\right)^{12}$, assim como uma curva de oferta de serviços $\left(\mathrm{S}_{\mathrm{R}}\right)$, que representa um insumo de comercialização (como transporte do açúcar refinado até o mercado varejista). A partir dessas curvas, obtém-se uma demanda derivada de açúcar refinado ao produtor, representada por $\left(\mathrm{D}_{\mathrm{RP}}\right)$ e, considerando a oferta

\footnotetext{
11 Preço equivalente refere-se ao preço na usina de uma unidade (quilograma, por exemplo) de açúcar/álcool em termos de cana-de-açúcar. Aqui vale lembrar que uma tonelada de cana-de-açúcar rende, aproximadamente, $112 \mathrm{~kg}$ de açúcar e 80 litros de álcool (Schouchana \& Widonsck, 2001).

${ }^{12}$ Considerar-se-á que todas as demandas a serem analisadas são negativamente inclinadas, ou seja, $\frac{\partial Q}{\partial P}<0$. Suas inclinações não representam as reais elasticidades.
} 
de serviços da indústria $\left(\mathrm{S}_{\mathrm{CR}}\right)$ para fabricação do açúcar refinado (tais como: os custos industriais, custos de refino e custos de empacotamento), obtém-se a demanda derivada por cana-de-açúcar para fabricação deste produto $\left(\mathrm{D}_{\mathrm{CR}}\right)$. Esse é o raciocínio que será adotado para todos os produtos.

Para o mercado de açúcar cristal, em função de sua utilização, é preciso fazer uma divisão em três submercados, quais sejam: açúcar cristal empacotado, açúcar cristal para indústria alimentícia, de bebidas etc. e açúcar cristal para exportação.

No primeiro submercado (cristal empacotado), considera-se uma demanda do varejo $\left(\mathrm{D}_{\mathrm{CV}}\right)$ e a curva de oferta de serviços para comercialização $\left(\mathrm{S}_{\mathrm{E}}\right)$, a partir das quais obtém-se uma demanda derivada de açúcar cristal empacotado ao produtor $\left(\mathrm{D}_{\mathrm{EP}}\right)$. Em seguida, tem-se a oferta de serviços da indústria para a fabricação desse produto $\left(\mathrm{S}_{\mathrm{CE}}\right)$, que representa os custos industriais e de empacotamento entre outros. Dessa oferta e da demanda ao produtor, deriva-se a curva de demanda por cana-de-açúcar para fabricação do açúcar cristal empacotado $\left(\mathrm{D}_{\mathrm{CE}}\right)$.

No submercado do açúcar cristal exportado, a análise é semelhante ao do açúcar cristal empacotado. Assume-se a demanda desse açúcar no mercado internacional $\left(\mathrm{D}_{\mathrm{CX}}\right)$ que, descontando-se os custos incorridos na operação de exportação $\left(S_{X}\right)$, possibilita derivar a demanda ao produtor $\left(\mathrm{D}_{\mathrm{XP}}\right)$. Para sua produção, a indústria oferta serviços $\left(\mathrm{S}_{\mathrm{CX}}\right)$, podendo-se derivar então a demanda por cana-de-açúcar $\left(\mathrm{D}_{\mathrm{CX}}\right)$.

Por fim, no submercado representado pelo açúcar cristal destinado à indústria, a diferença está em se considerar diretamente a demanda ao produtor derivada da demanda de açúcar das indústrias que utilizam esse produto como insumo $\left(\mathrm{D}_{\mathrm{IP}}\right)$. Para suprir essa demanda há oferta de serviços $\left(\mathrm{S}_{\mathrm{CI}}\right)$ e, dessas curvas, obtém-se a demanda derivada por cana-de-açúcar $\left(\mathrm{D}_{\mathrm{CI}}\right)$. Somando-se horizontalmente as demandas derivadas de cana-deaçúcar para fabricação do açúcar cristal em cada submercado $\left(\mathrm{D}_{\mathrm{CE}}, \mathrm{D}_{\mathrm{CX}}\right.$ e $\left.\mathrm{D}_{\mathrm{CI}}\right)$ obtém-se a demanda derivada total por cana-de-açúcar ao produtor $\left(\mathrm{D}_{\mathrm{CC}}\right)$ nesse mercado. 


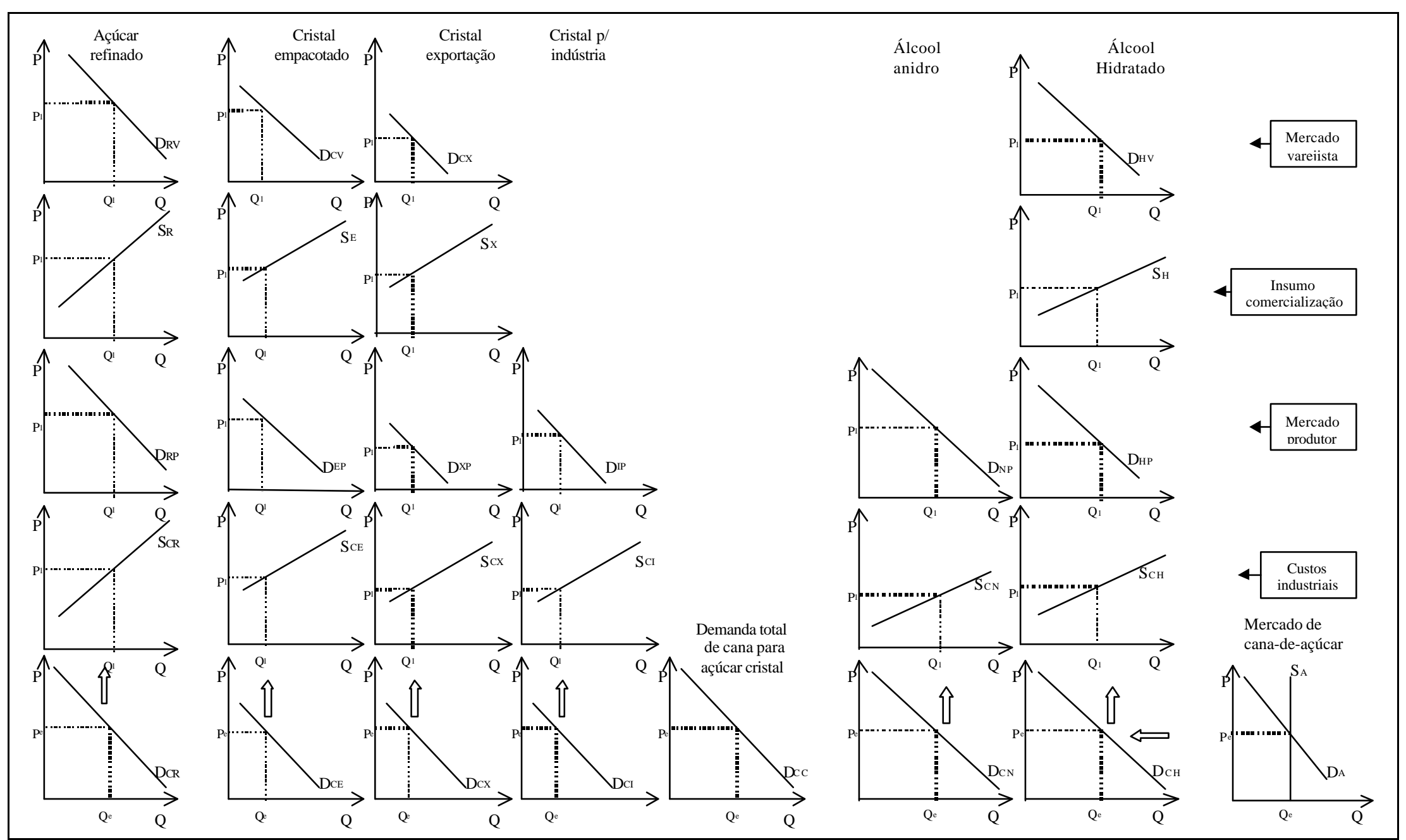

Figura 7 - Representação simplificada das inter-relações entre os mercados do setor sucroalcooleiro brasileiro.

Fonte: Elaborado pelo autor 
No mercado de álcool anidro, tem-se apenas um nível de mercado e, assim, considera-se uma demanda ao produtor derivada da demanda das distribuidoras $\left(\mathrm{D}_{\mathrm{NP}}\right)$. Considera-se, ainda, a oferta de serviços para sua fabricação $\left(\mathrm{S}_{\mathrm{CN}}\right)$, que representa os custos das unidades produtivas. A partir dessas curvas pode-se obter a demanda derivada de cana-de-açúcar para a fabricação do álcool $\left(\mathrm{D}_{\mathrm{CN}}\right)$. Para completar esta análise, representa-se o mercado de álcool hidratado tomando-se como dadas a demanda ao varejo $\left(\mathrm{D}_{\mathrm{HV}}\right)$ assim como a oferta de serviços de comercialização $\left(\mathrm{S}_{\mathrm{H}}\right)$. Dessas curvas, obtém-se a demanda derivada de álcool hidratado ao produtor $\left(\mathrm{D}_{\mathrm{HP}}\right)$ e, considerando a oferta de serviços da unidade produtora $\left(\mathrm{S}_{\mathrm{CH}}\right)$, deriva-se a demanda por cana-de-açúcar para sua fabricação $\left(\mathrm{D}_{\mathrm{CH}}\right)$.

A partir da soma horizontal das demandas derivadas de cana-de-açúcar em cada mercado [açúcar refinado $\left(\mathrm{D}_{\mathrm{CR}}\right)$; açúcar cristal $\left(\mathrm{D}_{\mathrm{CC}}\right)$; álcool anidro $\left(\mathrm{D}_{\mathrm{CN}}\right)$; e, álcool hidratado $\left(\mathrm{D}_{\mathrm{CH}}\right)$ ], obtém-se a demanda derivada total de cana-de-açúcar no setor sucroalcooleiro $\left(\mathrm{D}_{\mathrm{A}}\right)$. Supondo-se que a oferta de cana-de-açúcar é dada $\left(\mathrm{S}_{\mathrm{A}}\right)$ - curto prazo -, o cruzamento entre as curvas de oferta e de demanda dará o preço e quantidade de equilíbrio neste mercado.

Dados esse equilíbrio e custos equivalentes de cada produto em relação à cana de-açúcar, o próximo passo é determinar os preços e quantidades que vigorarão em cada mercado, de acordo com a Figura 7. A partir do equilíbrio no mercado de cana-deaçúcar, transporta-se o nível de preços para as demandas derivadas de cana em cada mercado, obtendo-se as quantidades demandadas que, por sua vez, darão os valores das ofertas de serviços para as usinas e destilarias, os preços e quantidades na curva de demanda de açúcar e álcool ao produtor, os custos dos insumos de comercialização e, por fim, os preços e quantidades nos mercados varejistas (açúcar refinado, cristal empacotado e para exportação e álcool hidratado).

Considera-se que o produtor esteja recebendo um mesmo valor ao destinar a cana-de-açúcar para fabricação de qualquer um dos produtos sob análise neste trabalho, pois se o destino a um dos produtos for mais rentável, há deslocamento de cana-deaçúcar para sua fabricação. Após a determinação da quantidade em cada mercado, espera-se que o valor da oferta de serviços do produtor no mercado de açúcar refinado 
seja maior, em relação ao açúcar cristal, por envolver mais etapas no processo de produção. O mesmo ocorre com o açúcar cristal empacotado, seguido dos valores dos serviços do açúcar destinado à indústria e exportação, respectivamente.

Tentou-se representar os preços ao produtor e ao varejo de acordo com a análise gráfica efetuada anteriormente (subcapítulo 2.2.3.1, deste trabalho). Por isso, o preço do açúcar refinado é maior, seguido do preço do açúcar cristal empacotado e do açúcar cristal industrial. Para o produtor de álcool, o preço do álcool anidro é superior ao do álcool hidratado.

Dessa forma, visualiza-se que a produção dos açúcares e dos alcoóis combustíveis estão interligadas, sendo bens produzidos pelo mesmo agente, a usina com destilaria anexa. Assim, o aumento no preço de um dos produtos conduz a um crescimento em sua oferta e conseqüente redução na oferta dos demais (ou de alguns) produtos.

Caso ocorra um choque de demanda no mercado varejista, por exemplo, no segmento de açúcar cristal empacotado, a curva de demanda $\left(\mathrm{D}_{\mathrm{CV}}\right)$ neste segmento desloca-se para direita (considerando um aumento exógeno na demanda). Esse aumento conduz a um deslocamento para a direita, na mesma magnitude, da curva de demanda derivada ao produtor no mercado de açúcar cristal empacotado $\left(D_{\mathrm{EP}}\right)$, nas curvas de demandas derivadas por cana-de-açúcar neste submercado $\left(\mathrm{D}_{\mathrm{CE}}\right)$, na demanda total para fabricação do açúcar cristal $\left(\mathrm{D}_{\mathrm{CC}}\right)$ e, consequentemente, na demanda derivada total por cana-de-açúcar no setor $\left(\mathrm{D}_{\mathrm{A}}\right)$.

O deslocamento na demanda derivada total por cana-de-açúcar para a direita produz um novo ponto de equilíbrio, com preço maior do que o inicialmente verificado, considerando que não houve alteração na oferta total de cana-de-açúcar. A partir deste novo preço, determinam-se os preços e quantidades que vigorarão em cada mercado como anteriormente feito.

Assim, no mercado de açúcar cristal empacotado, o novo equilíbrio ocorrerá com preço e quantidade maiores em todos os segmentos. Nos demais mercados, as quantidades diminuem e os preços aumentam, lembrando que, no caso das curvas de oferta de serviços, a quantidade e o valor monetário dos serviços diminuem. 
Diante das relações supracitadas, pode-se detalhar as inter-relações diretas descritas para cada segmento de mercado considerado. Propõe-se, através do uso da metodologia VAR, analisar as inter-relações de preços entre esses mercados, enfatizando o mercado de açúcar. Por simplificação, tendo em vista o pequeno número de observações, foram desconsiderados os mercados do açúcar refinado e do álcool hidratado. Dessa forma, a não inclusão do segmento de açúcar refinado na análise se deu em função da simplificação do modelo tendo em vista o número reduzido de dados na amostra. O mercado de álcool hidratado não será considerado devido à indisponibilidade de séries temporais para o período sob análise.

Primeiramente, supõe-se que o preço do açúcar cristal industrial tenha relação direta com os preços do açúcar cristal empacotado ao produtor, do açúcar cristal exportado e do álcool anidro (Figura 8). No mercado do açúcar cristal empacotado ao produtor, supõe-se uma relação direta com o segmento varejista e com o de açúcar cristal industrial. O açúcar cristal exportado, por sua vez, apresenta relação direta com o mercado de açúcar cristal industrial. Se o mercado interno estiver mais favorável, haverá maior destinação do açúcar cristal para este mercado e vice-versa. O açúcar cristal empacotado ao varejo apresenta relação direta apenas com o açúcar cristal empacotado ao produtor. Supõe-se que um aumento de preços ao produtor causa um aumento de preços ao varejo e vice-versa. No mercado produtor de álcool anidro, supõe-se relação direta com os mercados dos açúcares cristal industrial e exportado. Dessa forma, se o mercado de açúcar cristal apresentar-se favorável, sua oferta aumenta, reduzindo a oferta de álcool anidro.

Essas são as relações diretas que se pressupõe existir entre os preços dos produtos do setor. Entretanto, como não é possível definir a priori quais as inter-relações que realmente ocorrem contemporaneamente, propõe-se testar as seguintes hipóteses para estabelecer a matriz de relações contemporâneas:

- variação no preço do açúcar cristal industrial influencia os preços do açúcar cristal exportado e do álcool anidro;

- variação no preço do álcool anidro influencia os preços do açúcar cristal industrial e do açúcar cristal exportado; 
- variação no preço do açúcar cristal exportado influencia o preço do açúcar cristal industrial; e

- variação no preço do açúcar cristal empacotado ao varejo influencia o preço do açúcar cristal empacotado ao produtor.

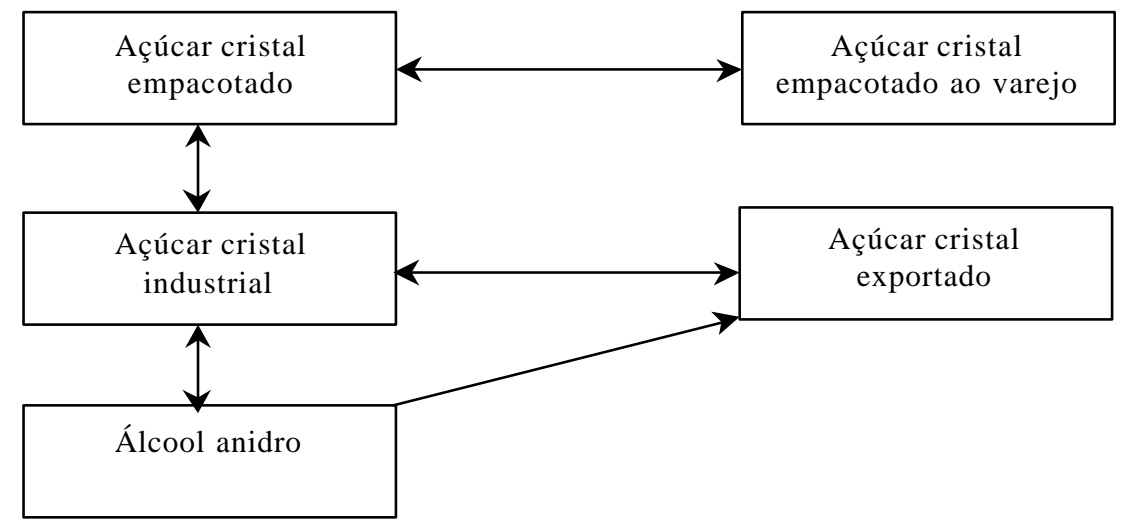

Figura 8 - Interdependência entre os mercados de açúcar e álcool.

Fonte: Elaborado pelo autor

A metodologia VAR permite que, após um primeiro momento, todas as variáveis sejam mutuamente influenciadas. Através dessa modelagem, é possível analisar as inter-relações no setor sucroalcooleiro brasileiro e o grau em que as oscilações de preços são transmitidas de um nível de mercado para outro e de um produto para outro de um mesmo nível de mercado. No próximo subcapítulo são descritas as fontes dos dados utilizados neste trabalho.

\subsubsection{Fonte dos dados}

Com a finalidade de analisar as inter-relações do setor sucroalcooleiro brasileiro, utilizaram-se cinco séries econômicas com dados mensais. As variáveis preço do açúcar cristal empacotado, preço do açúcar cristal industrial e preço do álcool anidro, todas para o mercado produtor, referem-se aos indicadores de preços levantados e divulgados pelo CEPEA (2002). Os preços para o mercado externo serão representados pelos valores do primeiro vencimento do contrato de açúcar negociado na LIFFE. 
Utilizar-se-ão os valores dessa Bolsa, uma vez que nesse contrato o Brasil fixa o preço do açúcar cristal cor 100 e 150, podendo, assim, efetuar comparações com o preço do mercado interno. Para os preços do açúcar cristal empacotado ao varejo, utiliza-se como proxy um índice divulgado pelo IBGE (2002).

As séries que apresentam dados em valores monetários foram deflacionadas através do Índice Geral de Preços ao Consumidor - Disponibilidade Interna (IGP-DI), calculado e divulgado pela Fundação Getúlio Vargas (FGV). Dado que os exportadores recebem em moeda nacional, os preços externos foram convertidos de dólar para a moeda nacional utilizando a taxa de câmbio nominal e, em seguida, essa série foi deflacionada da mesma maneira que as séries anteriores.

Isto posto, descrevem-se os métodos econométricos que possibilitam alcançar os objetivos propostos.

\subsection{Procedimentos}

Para alcançar os objetivos propostos, a metodologia empregada neste estudo inicia com os testes de raiz unitária em séries temporais. Essa metodologia foi proposta inicialmente nos trabalhos de Fuller (1976) e Dickey \& Fuller (1979; 1981), sendo completada posteriormente pelos trabalhos de Phillips \& Perron (1988). A segunda parte é composta pelos testes de co-integração entre as variáveis, desenvolvidos por Engle \& Granger (1987) e por Johansen (1988) e Johansen \& Juselius (1990). Posteriormente, são aplicados os modelos Auto-Regressivos Vetoriais (VAR), conforme estabelecido em Sims (1980). Esses testes serão realizados utilizando-se o software Regression Analysis Time Series (RATS). 


\subsubsection{Testes de raiz unitária}

A ordem de integração de uma variável diz respeito ao número de vezes que a série deve ser diferenciada (diferença do tipo $x_{t}-x_{t-1}$ ) para que ela se torne estacionária ${ }^{13}$. Conforme definem Engle \& Granger (1987), uma série sem componente determinístico, com representação ARMA (processos Auto-Regressivos de Médias Móveis), estacionária, invertível, após $d$ diferenças, é dita ser integrada de ordem $d$, denotada por $x_{t} \sim I(d)$. Portanto, a ordem de integração de uma variável representa o número de vezes que uma série precisa ser diferenciada para se tornar estacionária, ou seja, se uma variável é integrada de ordem 1, ela precisa ser diferenciada uma vez para atingir a estacionariedade.

Supondo que o processo gerador de dados é um passeio aleatório (random walk) dado por:

$x_{t}=x_{t-1}+\varepsilon_{t}$

$\operatorname{com} \varepsilon_{t}$ independente e identicamente distribuído (iid), com média zero e variância $\sigma^{2}$ $\left[\varepsilon_{t} \sim \operatorname{iid}\left(0, \sigma^{2}\right)\right]$. Após substituições sucessivas, tem-se:

$x_{t}=\sum_{j=1}^{t} \varepsilon_{j} \quad$ se $x_{0}=0$

onde $x_{t}$ é a somatória de $\varepsilon_{t}$ e $\Delta x_{t}=\varepsilon_{t}$ é $I(0)$, sendo $\Delta$ o operador de diferença, tal que $\Delta x_{t}=x_{t}-x_{t-1}$. Desse modo, tem-se que $x_{t}$ é $I(1)$, pois uma diferença foi suficiente para que a série se tornasse estacionária - diz-se então que a série tem uma raiz unitária.

\footnotetext{
${ }^{13}$ Estacionariedade implica que a série tem média e variância constantes ao longo do tempo e covariância dependendo apenas do intervalo de tempo (Gujarati, 2000).
} 
Dessa forma, um processo é integrado de ordem $1[(1)]$ se $x_{t}$ é não-estacionária mas a primeira diferença de $x_{t}\left[\Delta x_{t}\right]$ é estacionária.

O primeiro teste de raiz unitária foi desenvolvido Fuller (1976), considerando um processo auto-regressivo de ordem 1 [AR(1)], conforme descrito a seguir:

$$
x_{t}=\rho x_{t-1}+\varepsilon_{t}
$$

$\operatorname{com} \varepsilon_{t}$ ruído branco [white noise (iid)]. A hipótese nula é que $x_{t}$ é não-estacionário. Assim, tem-se que: $H_{0}: \rho=1$ contra $H_{A}:|\rho|<1$, o que eqüivale a testar em :

$$
\Delta x_{t}=(\rho-1) x_{t-1}+\varepsilon_{t}
$$

a hipótese $H_{0}: \rho-1=0$ contra $H_{A}: \rho-1<0$.

A aceitação da hipótese nula indica que o processo tem raiz unitária e, portanto, é não-estacionário. Para a realização deste teste de hipótese, utiliza-se como processo de estimação o método dos Mínimos Quadrados Ordinários. No entanto, os testes de raiz unitária e/ou de estacionariedade não utilizam a distribuição padrão $t$ de Student, mas os valores das distribuições denominadas $\tau$, as quais constam em Fuller (1976).

Considerando modelos que incorporam termos relacionados com a presença de intercepto e tendência, têm-se, respectivamente:

$$
\begin{aligned}
& x_{t}=\alpha+\rho x_{t-1}+\varepsilon_{t} \\
& \mathrm{e} \\
& x_{t}=\alpha+\beta t+\rho x_{t-1}+\varepsilon_{t}
\end{aligned}
$$


A estatística utilizada no caso de modelos com intercepto é denominada de $\tau_{\mu}$ e, para se testar a presença de tendência, utiliza-se a estatística $\tau_{\tau}$. Entretanto, é possível testar de maneira conjunta a presença de um termo de intercepto e/ou tendência e de raiz unitária, cujos testes são denominados $\phi$ e correspondem a um teste $\mathrm{F}$. No caso do teste denominado de $\phi_{1}$, testa-se a hipótese de que $(\alpha, \rho)=(0,1)$ contra a hipótese de que ( $\alpha$, $\rho) \neq(0,1)$. No teste $\phi_{2}$, a hipótese nula é que $(\alpha, \beta, \rho)=(0,0,1)$ contra a hipótese alternativa de que $(\alpha, \beta, \rho) \neq(0,0,1)$. Por fim, na estatística $\phi_{3}$, a hipótese nula é que ( $\alpha$, $\beta, \rho)=(\alpha, 0,1)$ contra a hipótese alternativa de que $(\alpha, \beta, \rho) \neq(\alpha, 0,1)$. Os valores críticos para essas distribuições estão tabulados em Dickey \& Fuller (1981).

Se a série for descrita por um processo auto-regressivo de ordem $p$, tem-se, para fim do teste, o seguinte modelo:

$$
\Delta x_{t}=\alpha+\beta t+\gamma x_{t-1}+\sum_{i=1}^{p-1} \lambda_{t} \Delta x_{t-i}+\varepsilon_{t}
$$

onde: $\lambda_{i}=-\sum_{j=i+1}^{p} \rho_{j}$ e $\gamma=\sum_{i=1}^{p} \rho_{i}-1$. Nesse caso, a presença de raiz unitária é testada pela hipótese $\mathrm{H}_{0}: \gamma=0$. O teste de raiz unitária, nesse exemplo, é denominado de Teste de Dickey-Fuller Aumentado (ADF).

Vários procedimentos têm sido utilizados para a determinação do valor de $p$, podendo-se citar os critérios de Akaike (AIC) e Schwarz (SC):

$$
\begin{aligned}
& \mathrm{AIC}=\ln \hat{\boldsymbol{\sigma}}^{2}+\left(\frac{2}{\mathrm{~T}}\right) \text { (número de parâmetros ) } \\
& \mathrm{SC}=\ln \hat{\boldsymbol{\sigma}}^{2}+\left(\frac{\ln \mathrm{T}}{\mathrm{T}}\right) \text { (número de parâmetros ) }
\end{aligned}
$$

onde $\hat{\boldsymbol{\sigma}}^{2}$ é a soma dos quadrados dos resíduos do processo auto-regressivo de ordem $p$ e $\mathrm{T}$ refere-se ao número de observações da amostra. Partindo de uma especificação geral 
(12 defasagens da variável dependente, por exemplo, se a série de dados utilizada for mensal), são feitos ajustamentos sucessivos eliminando-se as defasagens uma a uma, tomando-se como o modelo mais adequado aquele que apresentar o menor valor para ambos os critérios. O teste $Q$ de Ljung Box, por sua vez, dá uma indicação da existência ou não de autocorrelação serial, podendo ser utilizado como procedimento auxiliar na determinação do valor de $p$.

Pode-se resumir os testes de raiz unitária de acordo com o procedimento seqüencial proposto por Enders (1995):

1) estimar uma auto-regressão contendo um intercepto e uma variável tendência, considerando as defasagens determinadas pelos testes de AIC e SC, ou seja:

$$
\Delta x_{t}=\alpha+\beta t+\gamma x_{t-1}+\sum_{i=1}^{p-1} \lambda_{\iota} \Delta x_{t-i}+\varepsilon_{t}
$$

2) testa-se a hipótese que $\gamma=0$ utilizando-se a estatística $\tau_{\tau}$;

3) se a hipótese não for rejeitada, utiliza-se a estatística $\tau_{\beta \tau}$ para testar $\beta=0$. Se esta hipótese for rejeitada, testa-se $\gamma=0$ usando a distribuição normal;

4) se a hipótese $\beta=0$ não for rejeitada, deve-se estimar o modelo sem a variável tendência, mas com intercepto:

$$
\Delta x_{t}=\alpha+\gamma x_{t-1}+\sum_{i=1}^{p-1} \lambda_{1} \Delta x_{t-i}+\varepsilon_{t}
$$

5) Baseando-se nessa auto-regressão, deve-se testar a hipótese de $\gamma=0$ utilizando-se a estatística $\tau_{\mu}$

6) sua não-rejeição leva a testar a hipótese de que $\alpha=0$, utilizando a estatística $\tau_{\alpha \mu}$. Caso se rejeite essa hipótese, testa-se $\gamma=0$ usando a distribuição normal;

7) não se rejeitando a hipótese $\alpha=0$, estima-se o modelo sem intercepto e tendência: 
$\Delta x_{t}=\gamma x_{t-1}+\sum_{i=1}^{p-1} \lambda_{t} \Delta x_{t-i}+\varepsilon_{t}$

8) deve-se testar $\gamma=0$ utilizando a estatística $\tau$. Se essa hipótese não puder ser rejeitada, conclui-se que esse processo gerador da série possui raiz unitária. Portanto, deve-se trabalhar com a variável diferenciada e não em nível;

9) se isso ocorrer, repete-se o processo, porém considerando uma diferença a mais, para verificar se a série é $I(1)$. Se essa hipótese mais uma vez não for rejeitada, continuase o processo (aumentando-se o número de diferenças) até que o teste apresente-se significativo. Normalmente uma ou duas diferenças são suficientes para tornar a série estacionária.

\subsubsection{Testes de co-integração e mecanismo de correção de erro}

De forma intuitiva, o conceito de co-integração significa que variáveis nãoestacionárias podem ter caminho temporal ligados de forma que no longo prazo apresentem relação de equilíbrio. Segundo Engle \& Granger (1987), se duas séries de tempo $\left(y_{t}\right.$ e $\left.x_{t}\right)$ são $I(1)$, então, em geral, a combinação linear:

$$
y_{t}-\alpha-\beta x_{t}=\varepsilon_{t}
$$

também é $I(1)$, mas pode ocorrer que a combinação seja $I(0)$. Se este é o caso, a estimação não produzirá resultados espúrios. $\mathrm{O}$ conceito de co-integração está relacionado com uma relação de equilíbrio no longo prazo.

Componentes de um vetor $\mathbf{x}_{\mathbf{t}}$ são ditos serem co-integrados de ordem $d, b$, denotado por $\mathbf{x}_{\mathbf{t}} \sim C I(d, b)$, se: 1) todos os componentes são $I(d)$; e 2) existe um vetor $\mathbf{c} \neq$ 0 , tal que $\mathbf{z}_{\mathbf{t}}=\mathbf{c}^{\prime} \mathbf{x}_{\mathbf{t}} \sim I(d, b)>0$. O vetor $\mathbf{c}$ é chamado de vetor de co-integração. No 
caso em que $d=b=1$, todos os componentes do vetor $\mathbf{x}_{\mathbf{t}}$ são $I(1)$ e existe uma combinação linear desses componentes.

Em seguida, são expostos os procedimentos de Engle \& Granger e de Johansen para determinação das relações de co-integração entre variáveis.

\subsubsection{Método de Engle \& Granger}

Testar co-integração entre variáveis, de acordo com o conceito de Engle \& Granger (1987), significa verificar se as variáveis $y_{t}$ e $x_{t}$ têm caminho temporal ligado $[I(0)]$. Inicialmente é preciso verificar se tanto $y_{t}$ como $x_{t}$ são integradas de mesma ordem. Se ambas forem caracterizadas por um processo $I(1)$, por exemplo, para se testar se essas variáveis são co-integradas ou não, estima-se a seguinte equação:

$$
y_{t}=\alpha+\beta x_{t}+\varepsilon_{t}
$$

Em seguida, testa-se o resíduo estimado $\left(\varepsilon_{t}\right)$ para identificar se é estacionário $[(0)]$ ou não, através da aplicação de raiz unitária. Os valores críticos para os testes de raiz unitária sobre os resíduos da equação de co-integração podem ser encontrados em Engle \& Granger (1987).

Observada a relação de co-integração entre as variáveis, o próximo passo consiste na estimação do Modelo de Correção de Erro. De acordo com Engle \& Granger (1987), se yt e $x_{t}$ são ambas integradas de ordem um [I(1)] e são também co-integradas, então existe uma representação de Modelo de Correção de Erro dada por:

$$
\Delta y_{t}=w_{0}+w_{1} \Delta x_{t}-\Pi\left(y_{t-1}-\boldsymbol{\alpha}-\beta x_{t-1}\right)+v_{t}
$$

Esta equação representa a dinâmica de curto prazo e a equação (56), a dinâmica de longo prazo. 
Segundo Bittencourt (1995), ao se diferenciar os dados para se obter séries estacionárias perdem-se as informações de longo prazo, caso existam, conduzindo a estimativas viesadas dos parâmetros, assim como testes inválidos estatisticamente. Nesse contexto, há necessidade de incluir um componente que recupera esse desvio da trajetória de longo prazo das variáveis, chamado de Mecanismo de Correção de Erro (Bacchi, 1994). Este mecanismo consiste na inclusão do resíduo da equação de cointegração (defasado de um período) na estimação do modelo econométrico especificado nas diferenças, originando o Modelo com Correção de Erro.

Caso exista mais de um vetor de co-integração e/ou endogeneidade do regressor, a metodologia proposta por Engle \& Granger não é a mais indicada para testar co-integração. Nesse caso, sugere-se a aplicação do método desenvolvido por Johansen (1988) e por Johansen \& Juselius (1990), o qual é descrito em seguida.

\subsubsection{Método de Johansen}

Para especificar o modelo usado no teste de Johansen (1988), considera-se, inicialmente, uma representação de um Vetor Auto-Regressivo (VAR) de ordem $p$ de $X_{t}$ :

$$
\mathbf{x}_{\mathrm{t}}=\grave{\mathbf{i}}+\Xi_{1} \mathbf{x}_{\mathrm{t}-1}+\bigoplus_{2} \mathbf{x}_{\mathrm{t}-2}+\ldots+\bigoplus_{\mathrm{p}} \mathbf{x}_{\mathrm{t}-\mathrm{p}}+\stackrel{\AA}{\mathbf{t}}_{\mathrm{t}}
$$

onde $\mathbf{x}_{\mathbf{t}}$ é um vetor $(\mathrm{kx} 1)$ de variáveis $I(1) ; \mathbf{D}_{\mathbf{i}}$ são matrizes (kxk) de parâmetros; ì é

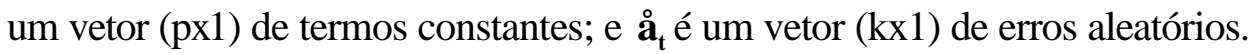

Aplicando procedimentos similares aos dos testes de raiz unitária, pode-se reparametrizar a equação (58):

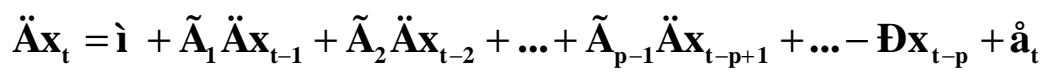

onde: $\tilde{\mathbf{A}}_{\mathrm{i}}=-\mathbf{I}+\mathbf{\Xi}_{1}+\mathbf{\Xi}_{2}+\ldots+\mathbf{\Xi}_{\mathrm{i}} \quad \mathrm{e} \quad(\mathrm{i}=1,2, \ldots, \mathrm{p}-1) ; \mathrm{e}$ 


$$
-\mathbf{\Xi}=\mathbf{I}-\boldsymbol{Ð}_{1}-\mathbf{Ð}_{2}-\ldots-\mathbf{\boxplus}_{\mathrm{p}}
$$

A expressão (59) é a representação tradicional de um modelo VAR nas diferenças, exceto pelo termo $\mathbf{Đ} \mathbf{x}_{\mathbf{t}-\mathbf{p}}$. Esse método consiste em testar se os coeficientes da matriz Đ contêm informações sobre as relações de longo prazo entre as variáveis envolvidas. Há três casos possíveis, de acordo com o posto da matriz Đ : a) se Đ tem posto completo, então $\mathbf{x}_{\mathbf{t}}$ é um processo estacionário e um modelo VAR em nível é apropriado; b) se $\mathbf{Ð}$ tem posto igual a zero, então $\mathbf{Ð}$ é uma matriz nula e $\mathbf{x}_{\mathbf{t}}$ é um processo integrado onde um modelo VAR nas diferenças é apropriado; c) se, entretanto, o posto da matriz está entre zero e $\mathbf{k}$, há co-integração e a matriz $\mathbf{Ð}$ pode ser representada pelo produto de duas matrizes $(\mathrm{kxr})$, á êâ , de modo que $\mathbf{\boxplus}=$ áấ ${ }^{\prime}$, onde $\hat{\mathbf{a}}$ contém os vetores de co-integração (são exatamente suas $r$ colunas) e á é o vetor de ponderação. Os vetores de co-integração de $\hat{\mathbf{a}}$ têm a propriedade de tornar $\hat{\mathbf{a}}^{\prime} \mathbf{x}_{\mathbf{t}}$ estacionário, quando $\mathbf{x}_{\mathbf{t}}$ é não-estacionário.

A hipótese nula de que existem $\mathbf{r}$ vetores co-integrados é testada usando-se a estatística traço $\left(\ddot{\mathbf{e}}_{\text {trace }}\right)$ e a estatística do máximo autovalor $\left(\ddot{\mathbf{e}}_{\text {max }}\right.$ ). Esses testes são aplicados seqüencialmente para valores decrescentes de r. Os valores críticos desses testes encontram-se em Johansen \& Juselius (1990) e em Osterwald-Lenum (1992).

Os testes do traço e do máximo autovalor são, respectivamente:

$$
\begin{aligned}
& \ddot{\mathbf{e}}_{\text {trace }}=-\mathrm{T} \sum_{\mathrm{i}=\mathrm{r}+1}^{\mathrm{k}} \ln \left(\mathbf{1}-\hat{\mathbf{e}}_{\mathrm{i}}\right) \\
& \ddot{\mathbf{e}}_{\max }=-\mathrm{T} \ln \left(1-\hat{\mathbf{\mathrm { e }}}_{\mathrm{r}+1}\right)
\end{aligned}
$$

onde $\hat{\ddot{\mathbf{e}}}_{i}$ são os autovalores estimados. Os critérios de AIC e SC, num contexto multiequacional, são utilizados para a determinação do valor de $p$. 


\subsubsection{Modelo Auto-Regressivo Vetorial (VAR)}

Modelos VAR foram propostos como alternativas aos modelos estruturais multiequacionais e têm sido muito utilizados na área econômica desde que foram introduzidos por Sims (1980). Sua principal característica consiste em tratar todas as variáveis de forma simétrica, ou seja, a questão relativa a quais variáveis devem ser consideradas dependentes ou independentes deixa de existir.

Esse modelo apresenta a vantagem de exigir um grau reduzido de restrições teóricas sobre a sua estrutura. Sua utilização exige apenas: a) especificar o conjunto de variáveis que se acredita que interagem dentro do sistema; e b) determinar o número de defasagens necessárias para captar a dinâmica de interação entre as variáveis do modelo.

Dentre os objetivos da utilização de modelos VAR está a obtenção das seguintes relações dinâmicas:

a) o tempo de reação das respostas a choques;

b) direção, padrão e duração das respostas;

c) intensidade das respostas a choques.

A obtenção de elasticidades de impulso-resposta para $k$ períodos à frente possibilita alcançar esses objetivos. Essas elasticidades permitem a avaliação do comportamento das variáveis em resposta a choques (inovações) individuais em quaisquer dos componentes do sistema, podendo-se, assim, analisar, através de simulação, efeitos de eventos que tenham alguma probabilidade de ocorrer $^{14}$. Outro mecanismo consiste na decomposição da variância dos erros de previsão $k$ períodos à frente em percentagens a serem atribuídas a cada variável componente do sistema, podendo-se assim aferir o poder explanatório de cada variável sobre as demais.

A metodologia VAR convencional tem como limitação o fato de ter uma estrutura recursiva para as relações contemporâneas entre as variáveis. Entretanto, o modelo conhecido como VAR estrutural, desenvolvido por Bernanke (1986), supera tal restrição e permite estabelecer relações contemporâneas tomando a teoria econômica

\footnotetext{
${ }^{14}$ A simu lação baseada na função impulso-resposta do VAR provê um mecanismo para estimar respostas a choques sem manter a pressuposição de condições ceteris paribus para as outras variáveis do modelo.
} 
como referência (Hamilton, 1994). A seguir são descritos os modelos VAR convencional e estrutural.

\subsubsection{Modelo VAR convencional}

Tendo como ponto de partida os modelos univariados de séries temporais, um processo auto-regressivo de ordem $p[\mathrm{AR}(\mathrm{p})]$ pode ser representado por:

$x_{t}=\phi_{1} x_{t-1}+\phi_{2} x_{t-2}+\ldots+\phi_{p} x_{t-p}+\varepsilon_{t}$

ou seja, o valor da variável escalar $\left(x_{t}\right)$ no período $t$ é função de seus próprios valores passados.

Ao invés de se considerar esse processo em termos de escalar, considera-o na forma vetorial, onde $x_{t}$ passa a ser um vetor coluna com $k$ diferentes variáveis. Obtém-se o seguinte vetor auto-regressivo:

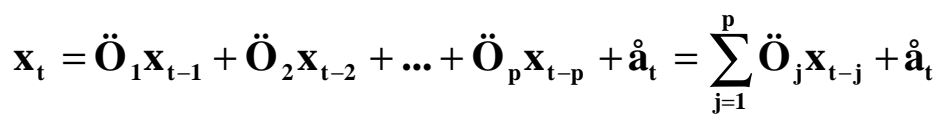

onde $\mathbf{x}_{\mathbf{t}}$ é um vetor $(\mathrm{kx} 1)$ das variáveis do modelo; $\ddot{\mathbf{O}}_{\mathbf{j}}(\mathrm{j}=1,2, \ldots, p)$ são matrizes (kxk) de coeficientes que relacionam os valores defasados com os valores correntes das variáveis; e $\AA_{\mathbf{a}}$ é um vetor (kx1) de erros ruído branco (white noise), com as seguintes propriedades:

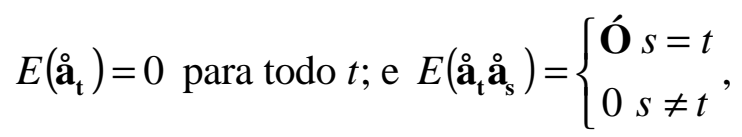

onde Ó é a matriz de variância-covariância a qual pressupõe-se ser positiva definida. Os termos ă são serialmente não-correlacionados, mas podem ser contemporaneamente correlacionados. 
A equação (63) pode ser reescrita como:

$\mathbf{B}(\mathrm{L}) \mathbf{x}_{\mathrm{t}}=\stackrel{\circ}{\mathbf{a}}_{\mathrm{t}}$

onde $\mathrm{L}$ é um operador de defasagem tal que $L^{p} Z_{t}=Z_{t-p}$; e $\mathbf{B}(\mathrm{L})$ é um polinômio definido como:

$\mathbf{B}(\mathrm{L})=\mathbf{B}_{0}-\mathbf{B}_{\mathbf{1}} \mathrm{L}-\mathbf{B}_{\mathbf{2}} \mathrm{L}^{2}-\ldots-\mathbf{B}_{\mathbf{p}} \mathrm{L}^{\mathrm{p}} \quad p=1,2, \ldots, \infty ;$ e $\mathbf{B}_{\mathbf{0}}=\mathbf{I}$

Sendo $\mathbf{x}_{\mathbf{t}}$ um processo estocástico estacionário, as condições de invertibilidade são observadas e pode-se obter a seguinte representação de Média Móvel Vetorial (VMA):

$\mathbf{x}_{\mathbf{t}}=\mathbf{A}(\mathrm{L}) \mathbf{a}_{\mathbf{t}}$

onde $\mathbf{A}(\mathrm{L})=\mathbf{A}_{0}+\mathbf{A}_{1} \mathrm{~L}+\mathbf{A}_{2} \mathrm{~L}^{2}+\ldots+\mathbf{A}_{\mathbf{P}} \mathrm{L}^{\mathrm{P}}$, sendo $p=1,2, \ldots, \infty$ e $\mathbf{A}_{0}=\mathbf{I}$. O número de defasagens $p$ a ser utilizado no modelo VAR pode ser determinado pelos procedimentos de Akaike e Schwarz.

A partir da equação (63) é possível obter:

a) as estimativas dos coeficientes;

b) as respostas a choques, através da função de resposta de impulso na representação de média móvel (66);

c) a decomposição da variância do erro de previsão.

Os coeficientes são estimados por Mínimos Quadrados Ordinários. Por outro lado, para se obter as respostas a choques é preciso reescrever a equação (66) como:

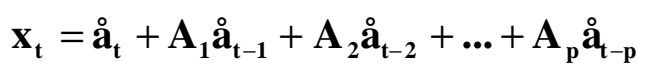


Deste modo, o efeito de um choque unitário no $i$-ésimo componente do vetor de inovações no período $t$ - $p$ sobre $\mathbf{x}_{\mathbf{n}}$ no período t é medido na $i$-ésima coluna de $\mathbf{A}_{\mathbf{p}}$. Assim, o comportamento dinâmico das variáveis em resposta a choques em quaisquer dos componentes do sistema é analisado pela estimação da equação (67).

Entretanto, quando se trabalha com modelos VAR, torna-se necessário efetuar alguns ajustes em relação à matriz de variância-covariância dos resíduos (ó), pois geralmente essa é não diagonal, o que implica que os choques podem ocorrer simultaneamente com probabilidades diferentes de zero. Portanto, torna-se necessário diagonalizar a matriz de variância-covariância. O procedimento usual para esta diagonalização é efetuar a decomposição de Cholesky.

Admitindo que a matriz de variância-covariância seja não-singular, então, existe uma matriz $\mathbf{C}$, triangular inferior e não-singular, tal que $\mathbf{\mathbf { O }}=\mathbf{C} \mathbf{C}^{\prime}$, sendo que: $\mathbf{C}^{-1} \mathbf{O}\left(\mathbf{C}^{\prime}\right)^{-1}=\mathbf{I}$. A seguir define-se $\mathbf{c}_{\mathbf{t}}=\mathbf{C}^{-1} \mathbf{e}_{\mathbf{t}}$ e obtém-se $E\left[\mathbf{c}_{\mathbf{t}} \mathbf{c}_{\mathbf{t}}^{\prime}\right]=\mathbf{I}^{15}$.

Continuando o processo de diagonalização da matriz de variância-covariância, pré-multiplicam-se os dois lados da equação (64) por $\mathbf{C}^{-1}$, resultando em:

$$
C^{-1} \mathbf{B}_{0} \mathbf{x}_{t}-C^{-1} B_{1} x_{t-1}-C^{-1} B_{2} x_{t-2}-\ldots-C^{-1} B_{p} x_{t-p}=H(L) x_{t}=c_{\mathfrak{t}}
$$

onde $\mathbf{H}(\mathrm{L})=\mathbf{C}^{-1} \mathbf{B}(\mathrm{L})=\mathbf{C}^{-1} \mathbf{A}(\mathrm{L})^{-1}$. Na representação de médias móveis tem-se:

$$
\mathbf{x}_{\mathrm{t}}=\mathbf{G}(\mathrm{L}) \mathbf{c}_{\mathbf{t}}
$$

sendo $\mathbf{G}(\mathrm{L})=\mathbf{A}(\mathrm{L}) \mathbf{C}$ e $\mathbf{c ̧}_{\mathbf{t}}$ é um ruído branco.

Nesse contexto, tendo como base a equação (69) é possível medir o efeito de um choque unitário de um desvio-padrão em apenas uma das variáveis do sistema sobre todas as outras. Se ocorrerem choque de um desvio-padrão na variável $i$, em $t$-j, tem-se o impacto sobre $\mathbf{x}$ no período $t$, através da $i$-ésima coluna de $\mathbf{G}_{\mathbf{j}}$.

$\left.{ }^{15} E\left[\mathbf{c}_{\mathbf{t}} \mathbf{c}_{\mathbf{t}}^{\prime}\right]=E\left[\mathbf{C}^{-1} \mathbf{e}_{\mathbf{t}} \mathbf{e}_{\mathbf{t}}^{\prime}\left(\mathbf{C}^{\prime}\right)^{-1}\right]=\mid \mathbf{C}^{-1} \mathbf{O}\left(\mathbf{C}^{\prime}\right)^{-1}\right]=\mathbf{I}$ 
As inovações ortogonalizadas têm a vantagem sobre as demais por não serem correlacionadas. Contudo, segundo Bliska \& Barros (1990, p.46),

“(...) há uma decomposição diferente para cada ordenação das variáveis, sendo que a direção do efeito captado decorre da seleção arbitrária da ordem das variáveis no vetor analisado. Logo, quanto menor a covariância contemporânea (menor correlação entre os resíduos) menor é a importância da ordem selecionada".

Daí a necessidade de uma estrutura econômica para se determinar, com embasamento teórico, a ordem que as variáveis devem ocupar no vetor de variáveis do sistema.

A decomposição da variância do erro de previsão é outro ponto a ser analisado para caracterizar o inter-relacionamento entre as variáveis do modelo. $\mathrm{O}$ erro de previsão de $p$ períodos à frente é definido por:

$\stackrel{\circ}{\mathbf{a}+\mathbf{p}}_{\mathbf{t}+\mathbf{p}}-E\left[\mathbf{x}_{\mathbf{t}+\mathbf{p}} / \mathbf{x}_{\mathbf{t}}, \mathbf{x}_{\mathbf{t}-1}, \ldots\right]$

e, lembrando que $E\left[\mathbf{a}_{\mathbf{t}} \stackrel{\circ}{\mathbf{t}}_{\mathbf{t}}^{\prime}\right]=\mathbf{\mathbf { O }}=\mathbf{C C}^{\prime}$. Os elementos da diagonal principal são a soma de quadrados dos resíduos.

De (69) e (70) tem-se que:

$\mathbf{x}_{t+p}=\mathbf{G}_{0} \mathbf{c}_{t+p}+\mathbf{G}_{1} \boldsymbol{c}_{\mathrm{t}+\mathbf{p}-1}+\ldots+\mathbf{G}_{p-1} \mathbf{c}_{t+1}+\mathbf{G}_{p} \mathbf{c}_{t}+\mathbf{G}_{p+1} \mathbf{c}_{t-1}+\ldots$

e por isso:

$\mathbf{x}_{t+p}-\mathbf{E}\left[\mathbf{x}_{t+p} / \mathbf{x}_{t}, \mathbf{x}_{t-1}, \ldots\right]=\sum_{j=0}^{p-1} G_{j} \mathbf{c}_{t+p-j}$

A matriz de variância-covariância de $p$ períodos a frente é dada por: 
$\sum_{j=0}^{p-1} A_{j} \mathbf{O} \mathbf{A}_{j}^{\prime}=\sum_{j=0}^{p-1}\left(A_{j} C\right)\left(A_{j} C\right)^{\prime}$

\subsubsection{Modelos VAR estruturados e/ou identificáveis}

Esses modelos se diferenciam dos convencionais por considerarem hipóteses estruturais, não necessariamente recursivas, facilitando a interpretação econômica dos resultados (Bittencourt, 1995). A representação geral do modelo VAR, neste caso, é a seguinte:

$\ddot{O}_{0} x_{t}=\sum_{s=1}^{p} \ddot{O}_{s} x_{t-s}+B_{0} \stackrel{̊}{t}_{t}$

sendo que $\mathbf{x}_{\mathbf{t}}$ corresponde ao vetor de variáveis consideradas no modelo; $\boldsymbol{\Phi}_{\mathbf{0}}$ é a matriz de coeficientes de relações contemporâneas de ordem (kxk) (nesta matriz serão impostas as restrições sobre os coeficientes); $\boldsymbol{\Phi}_{\mathrm{s}}$ são matrizes de ordem (kxk) contendo coeficientes de relações defasadas de ordem $p$ entre as variáveis; $\AA_{\mathbf{a}}$ é um vetor de choques ortogonais com média zero e não-correlacionado e $\mathbf{B}_{\mathbf{0}}=\mathbf{I}$.

A expressão estrutural (74) pode ser reescrita na forma reduzida, prémultiplincando ambos os lados pela inversa da matriz de coeficientes de interações contemporâneas:

$$
\mathbf{x}_{t}=\sum_{s=1}^{p} \ddot{O}_{0}^{-1} \ddot{O}_{s} \mathbf{x}_{t-s}+\ddot{O}_{0}^{-1} \mathbf{B}_{0} \stackrel{̊}{\mathbf{a}}_{t}
$$

A estimação da forma reduzida é feita por Mínimos Quadrados Ordinários, obtendo-se os seus correspondentes resíduos:

$$
\grave{\mathbf{i}}_{\mathrm{t}}=\ddot{\mathbf{O}}_{0}^{-1} \stackrel{\mathrm{a}}{\mathbf{t}}_{\mathrm{f}}
$$


cuja matriz de covariância $\left[\operatorname{Cov}\left(\grave{\mathbf{I}}_{\mathbf{t}}\right)=\mathbf{\mathbf { O }}\right]$ será utilizada para estimar $\ddot{\mathbf{O}}_{0}^{-1}$. Essa matriz possui $\mathrm{n}(\mathrm{n}+1) / 2$ parâmetros livres que podem ser estimados.

Para estimação da equação (74), utiliza-se o procedimento de Bernanke incorporado ao programa RATS. Após a estimação de (75) por Mínimos Quadrados Ordinários, o passo seguinte consiste na maximização da função logarítmica de verossimilhança de $\stackrel{\mathbf{a}}{\mathbf{t}}_{\mathbf{t}}$ em (76), o qual é distribuído multinormalmente, enquanto que D é a diagonal da matriz de variância-covariância dos erros do modelo $\left[\mathbf{D}=\operatorname{Cov}\left(\mathbf{a}_{\mathbf{t}}\right)\right]$. Matematicamente, tem-se:

$$
\ln L=-T\left(\frac{n}{2}\right) \ln (2 \pi)+T\left[\ln \ddot{\mathbf{O}}_{0}\left|-\left(\frac{1}{2}\right) \ln \right| \mathbf{D} \mid\right]-\left(\frac{T}{2}\right) \operatorname{rr}\left(\mathbf{D}^{-1} \ddot{\mathbf{O}}_{0} \mathbf{\mathbf { O }} \ddot{\mathbf{O}}_{0}^{-1}\right)
$$

Após estimar as matrizes $\ddot{\mathbf{O}}_{0}$ e $\mathbf{D}$, procedem-se as análises da função de resposta de impulso e decomposição da variância dos erros de previsão para cada variável.

O modelo VAR pode ser escrito na forma de médias móveis:

$$
\mathbf{x}_{\mathbf{t}}=\sum_{j=1}^{\infty} \mathbf{C}_{\mathbf{j}} \mathbf{i}_{\mathbf{t}-\mathbf{j}}
$$

onde $\mathbf{C}_{\mathbf{j}}$ são as matrizes que medem os impactos do vetor de erros. A expressão (78) pode ser reescrita da seguinte forma:

$$
\mathbf{x}_{\mathbf{t}}=\sum_{j=1}^{\infty} \mathbf{C}_{\mathbf{j}} \ddot{\mathbf{O}}_{0}^{-1} \mathbf{D}^{1 / 2} \stackrel{a}{\mathbf{t}}_{\mathbf{t}}
$$

onde os choques unitários em $\mathbf{a}_{\mathbf{t}}$ multiplicados pela raiz quadrada de $\mathbf{D}$ são equivalentes a choques de um desvio-padrão. Essa expressão também será usada para obtenção da decomposição da variância de previsão.

No capítulo seguinte, apresentam-se e discutem-se os resultados. 


\section{RESULTADOS E DISCUSSÃO}

Esse capítulo, no qual se faz a análise dos resultados, está dividido em dois subcapítulos. No primeiro, apresentam-se os testes de raiz unitária, identificando a estacionariedade e/ou a ordem de integração das variáveis. Com esse procedimento objetiva-se evitar obter um relacionamento espúrio entre as variáveis e verificar se é possível a realização dos testes de co-integração. Posteriormente, são apresentados e discutidos os resultados dos testes de co-integração entre as variáveis integradas de mesma ordem. No segundo subcapítulo são analisados os resultados dos modelos AutoRegressivos Vetoriais com Termos de Correção de Erro (VEC) de cada uma das hipóteses adotadas no modelo econômico para construção da matriz de relações contemporâneas. Dessa forma, na primeira seção desse subcapítulo são discutidos os resultados do modelo construído sob a hipótese de que variação no preço do açúcar cristal industrial influencia de forma contemporânea os preços do açúcar cristal exportado e do álcool anidro. Na segunda seção, analisam-se os resultados do modelo construído sob a hipótese de que variação no preço do álcool anidro influencia os preços do açúcar cristal industrial e do açúcar cristal exportado. Em seguida (seção três), é discutido o modelo fundamentado na hipótese de que variação no preço do açúcar cristal exportado influencia o preço do açúcar cristal industrial e, por fim (seção quatro), o modelo fundamentado na hipótese de que variação no preço do açúcar cristal empacotado ao varejo influencia o preço do açúcar cristal empacotado ao produtor é analisado. Apresenta-se, primeiramente, na Tabela 5, a relação das variáveis utilizadas e as respectivas nomenclaturas adotadas, ressaltando que as mesmas são consideradas em logaritmo nas análises econométricas. 
Tabela 5. Descrição das variáveis utilizadas na presente pesquisa.

\begin{tabular}{cl}
\hline Variável & \multicolumn{1}{c}{ Definição } \\
\hline lnani & logaritmo neperiano dos preços do álcool anidro \\
lnind & logaritmo neperiano dos preços do açúcar cristal industrial \\
lnexp & logaritmo neperiano dos preços do açúcar cristal exportado \\
lnemp & logaritmo neperiano dos preços do açúcar cristal empacotado ao produtor \\
lnemv & logaritmo neperiano dos preços do açúcar cristal empacotado ao varejo \\
\hline
\end{tabular}

Fonte: Elaborado pelo autor

\subsection{Testes de raiz unitária}

Para determinar a ordem do processo auto-regressivo a ser adotado nos testes de raiz unitária, foram utilizados os critérios de Akaike (AIC) e Schwarz (SC), conforme descrito no subcapítulo 3.3.1. Esses resultados estão na Tabela 6, indicando que as séries lnind e lnexp são descritas por um processo auto-regressivo de ordem um [AR(1)], enquanto as séries lnani e lnemv são descritas por um processo $\operatorname{AR}(2)$ e a série lnemp por um processo $\mathrm{AR}(4)$.

Após a identificação da ordem do processo auto-regressivo das séries, realizouse o teste de Dickey-Fuller Aumentado (ADF). Adotou-se o procedimento proposto por Enders (1995) para identificar o modelo específico a ser considerado no teste, utilizando o sistema seqüencial descrito no subcapítulo 3.3.1.

Os testes de ADF, cujos resultados podem ser analisados na Tabela 6, indicam que os elementos deterministas tendência e constante não devem ser incluídos no modelo construído com a finalidade de testar a presença de raiz unitária e que as séries não são estacionárias em nível. Repetiu-se o ajustamento para verificar se as séries tornam-se estacionárias quando analisadas nas primeiras diferenças. Esses resultados são apresentados na última coluna da Tabela 6 (Modelo 2), onde se verifica que todos os coeficientes são significativos. Assim, as variáveis são integradas de ordem um [I(1)] e na especificação do modelo VAR devem ser consideradas nas diferenças de primeira ordem. 
Tabela 6. Resultados dos testes de raiz unitária de Dickey-Fuller para as séries de preços lnani, lnind, lnexp, lnemp e lnemv.

\begin{tabular}{lccccccc}
\hline Variá- & $\begin{array}{c}\text { Valor } \\
\text { veis }\end{array}$ & de $p-1$ & $\tau_{\tau}$ & $\tau_{\beta \tau}$ & $\tau_{\mu}$ & $\tau_{\alpha \mu}$ & \multicolumn{1}{c}{ Modelo 2** } \\
\cline { 3 - 6 } lnani & 1 & -1.74 & 0.79 & -1.66 & -1.61 & -0.44 & \\
lnind & 0 & -1.92 & 1.26 & -1.44 & -1.47 & -0.09 & $-4.61^{\#}$ \\
lnexp & 0 & -2.43 & 1.23 & -2.08 & -1.98 & -0.66 & $-5.97^{\#}$ \\
lnemp & 3 & -1.94 & 0.92 & -1.83 & -1.70 & -0.71 & $-5.96^{\#}$ \\
lncvar & 1 & -2.83 & 2.17 & -1.80 & -1.79 & -0.20 & $-3.23^{\#}$ \\
\hline
\end{tabular}

Fonte: Dados da pesquisa

\# Significativo ao nível de 5\% de significância [valores críticos em Fuller (1976) e Dickey-Fuller (1981)].

* Modelo $1=\Delta x_{t}=\alpha+\beta t+\gamma x_{t-1}+\sum_{i=1}^{p-1} \lambda_{t} \Delta x_{t-i}+\varepsilon_{t}$, nas versões com constante e tendência, sem tendência e sem tendência e constante.

** Modelo $2=\Delta \Delta x_{t}=\gamma \Delta x_{t-1}+\sum_{i=1}^{p-2} \lambda_{t} \Delta \Delta x_{t-i}+\varepsilon_{t}$, definido após constatado a não existência de termos deterministas.

Obs.: não houve presença de autocorrelação serial, conforme o teste $Q$ de Ljung Box.

Após verificar que as variáveis são integradas de mesma ordem, deve-se fazer os testes de co-integração para analisar as relações de longo prazo entre elas. O método utilizado foi o proposto por Johansen (1988) e os resultados constam na Tabela 7.

O número de defasagem utilizado (duas) foi definido de acordo com os critérios de AIC e SC, para uma versão multiequacional. Os testes do máximo autovalor $\left(\ddot{\mathbf{e}}_{\max }\right)$ e do traço $\left(\ddot{\mathbf{e}}_{\text {trace }}\right)$ apresentaram valores significativos a partir da hipótese nula de que há pelo menos um vetor de co-integração $(\mathrm{r} \leq 1)$ contra a hipótese alternativa de que há dois vetores de co-integração $(r=2)$. Dessa forma, devem ser considerados no modelo dois vetores de co-integração. Em suma, os resultados mostram que há relações de equilíbrio de longo prazo entre as variáveis. O modelo a ser ajustado deve, portanto, ser um modelo de Auto-Regressão Vetorial com Correção de Erro (VEC), para considerar os aspectos tanto de curto quanto de longo prazos. 
Tabela 7. Resultados dos testes de co-integração de Johansen entre as séries de preços lnani, lnind, lnexp, lnemp e lnemv.

\begin{tabular}{cccc}
\hline Hipótese Nula & Hipótese Alternativa & $\ddot{\mathbf{e}}_{\max }$ & $\ddot{\mathbf{e}}_{\text {trace }}$ \\
\hline $\mathrm{r} \leq 4$ & $\mathrm{r}=5$ & 4.721 & 4.721 \\
$\mathrm{r} \leq 3$ & $\mathrm{r}=4$ & 8.398 & 13.119 \\
$\mathrm{r} \leq 2$ & $\mathrm{r}=3$ & 17.385 & 30.504 \\
$\mathrm{r} \leq 1$ & $\mathrm{r}=2$ & $34.831^{*}$ & $65.335^{*}$ \\
$\mathrm{r} \leq 0$ & $\mathrm{r}=1$ & $47.928^{*}$ & $113.263^{*}$ \\
\hline
\end{tabular}

Fonte: Dados da pesquisa

* Significativo a 5\% de significância [valores críticos em Osterwald-Lenum (1992)]. Modelo com constante restrita, ajustado com duas defasagens.

\subsection{Modelos de Auto-Regressão Vetorial com Correção de Erro (VEC) com identificação pelo processo de Bernanke}

\subsubsection{Modelo 1: influência contemporânea do preço do açúcar cristal industrial sobre os preços do açúcar cristal exportado e do álcool anidro}

Nessa seção, relatam-se os resultados do ajustamento do modelo VEC considerando apenas a influência contemporânea do preço do açúcar cristal industrial sobre os preços do açúcar cristal exportado e do álcool anidro, conforme apresentado na Figura 9. Espera-se que os sinais dos coeficientes da matriz de relações contemporâneas sejam todos positivos, uma vez que o aumento do preço do açúcar cristal industrial deve fazer com que os produtores destinem mais matéria-prima para sua fabricação, acarretando em redução de oferta dos demais produtos e aumento de seus preços.

A matriz estimada de coeficientes de relações contemporâneas apresentou os resultados mostrados na Tabela 8. Os sinais dos coeficientes estão de acordo com o esperado (estes devem ser analisados ao contrário dos apresentados), porém é nãosignificativo para a relação entre os preços do álcool anidro e do açúcar cristal industrial (leiam-se: linha=Inani e coluna=lnind) e significativo para a relação entre os preços dos açúcares cristal exportado e cristal industrial (leiam-se: linha=lnexp e coluna=lnind). Esse resultado mostra que um aumento de $1 \%$ no preço do açúcar cristal industrial no mercado interno causa um aumento de $0,21 \%$ no preço de exportação. 
Vale ressaltar que a inexistência de relação contemporânea entre os preços do açúcar cristal industrial e do álcool anidro também foi registrada por Costa (2000). Dessa forma, mesmo utilizando séries com maior período de abrangência do que os considerados por essa autora, não se obteve neste trabalho relação expressiva entre esses produtos.

\begin{tabular}{l|ccccc}
\multicolumn{1}{c}{} & lnind & lnani & lnexp & lnemp & lnemv \\
\cline { 2 - 6 } lnind & 1 & 0 & 0 & 0 & 0 \\
$\operatorname{lnani}$ & 1 & 1 & 0 & 0 & 0 \\
lnexp & 1 & 0 & 1 & 0 & 0 \\
lnemp & 0 & 0 & 0 & 1 & 0 \\
lnemv & 0 & 0 & 0 & 0 & 1
\end{tabular}

Figura 9 - Matriz de relações contemporâneas.

Fonte: Elaborado pelo autor

Tabela 8. Estimativa da matriz de coeficientes de relações contemporâneas (Modelo 1).

\begin{tabular}{|c|c|c|c|}
\hline \multicolumn{2}{|c|}{ Relações } & \multirow[t]{2}{*}{ Coeficientes } & \multirow[t]{2}{*}{ Desvio-padrão } \\
\hline Linha & Coluna & & \\
\hline lnani & lnind & $-0,0058$ & 0,069 \\
\hline $\operatorname{lnexp}$ & lnind & $-0,2111$ & 0,153 \\
\hline
\end{tabular}

Fonte: Dados da pesquisa

Como mencionado no tópico referente aos procedimentos metodológicos, a metodologia VAR permite avaliar o poder explanatório de cada variável do modelo sobre as demais através da decomposição da variância dos erros de previsão. Nas Tabelas 9 a 13 constam as referidas decomposições, assim como a estimativa do desviopadrão dos erros de previsão. Optou-se por apresentar as decomposições somente para sete meses após o choque, uma vez que nos períodos posteriores a parcela de explicação de cada variável sobre as demais não sofre alteração significativa em relação a este mês.

$\mathrm{Na}$ decomposição da variância do erro de previsão do preço do açúcar cristal industrial (Tabela 9) observa-se que a quase totalidade das variações é explicada pela própria variável durante todo o período, cuja média é de aproximadamente 92,5\%. No geral, observa-se que as demais variáveis não apresentam influência significativa sobre o preço do açúcar cristal industrial, sendo que apenas os preços do açúcar cristal empacotado ao produtor e ao varejo explicam um pouco das variações do preço dessa variável (média de $4 \%$ e 2,7\%, respectivamente). As parcelas explicadas pelos preços do 
álcool anidro e do açúcar cristal exportado são pouco representativas (médias de 0,5\% e $0,3 \%$, respectivamente).

Os resultados da Tabela 10 mostram que a maior parte das variações do preço do álcool anidro depende da própria variável (média de 65,2\%). O preço do açúcar cristal industrial explica, em média, $18,8 \%$ das variações no preço do álcool anidro, sendo que a partir do sexto mês ele passa a explicar mais de $29 \%$ das variações desse preço. O preço do açúcar cristal empacotado ao produtor explica, em média, $10 \%$ do preço do álcool anidro. Dessa forma, tem grande expressão a parcela explicada pelo próprio preço do álcool anidro e o relativamente elevado relacionamento desse preço com o do açúcar cristal industrial e com o preço do açúcar cristal empacotado. Observase, também, uma maior influência do preço do açúcar cristal industrial sobre o preço do álcool anidro do que o contrário.

Na Tabela 11, observa-se a quase total independência do preço de exportação em relação aos preços do mercado interno nos dois primeiros períodos. No entanto, a partir do terceiro período, os preços dos produtos do mercado interno passam a ter maior influência sobre o preço de exportação. Os preços do açúcar cristal industrial e do açúcar cristal empacotado ao produtor são os responsáveis pelas maiores parcelas de explicação (médias de 17,5\% e 9,9\%, respectivamente). As parcelas explicadas pelos preços do álcool anidro e açúcar cristal empacotado ao varejo são de 4,9\% e 3\%, respectivamente, portanto, de pequena magnitude.

A decomposição da variância do erro de previsão do preço do açúcar cristal empacotado ao produtor (Tabela 12) mostra a dependência desse preço em relação aos de açúcar cristal industrial e de cristal empacotado ao varejo, em menor intensidade. Em média, a própria variável explica 70,6\% de sua variância; o preço do açúcar cristal industrial explica 19,9\%; e o preço do açúcar cristal empacotado ao varejo $5,1 \%$. As demais variáveis têm menor poder explanatório.

A decomposição da variância do erro de previsão do preço do açúcar cristal empacotado ao varejo é apresentada na Tabela 13. Os resultados mostram que uma parcela significativa da explicação dos erros de previsão dessa variável deve-se ao preço do mercado produtor do açúcar cristal empacotado. Considerando a parcela explicada 
pela própria variável, que diminui com o tempo, e a do preço do açúcar cristal empacotado ao produtor, tem-se que $91,4 \%$ das variações do preço do açúcar cristal empacotado ao varejo devem-se a essas duas variáveis.

Analisa-se nas Figuras 10 a 14 o impacto que um choque em cada variável causa sobre si mesma e nas demais variáveis do modelo nos períodos seguintes ao que ocorreu o choque. Optou-se por apresentar apenas as respostas de choques que mostraram alguma expressão e/ou de variáveis que tiveram uma parcela de explicação expressiva na decomposição da variância dos erros de previsão.

Um choque no preço do açúcar cristal industrial (Figura 10) causa um aumento no preço do açúcar cristal exportado no primeiro período, conforme já se havia verificado na estimativa da matriz de relações contemporâneas. $\mathrm{O}$ maior efeito de uma variação no preço do açúcar cristal industrial sobre o preço de exportação ocorre no terceiro mês após o choque. Os impactos sobre os preços do álcool anidro e do açúcar cristal empacotado ao produtor ocorrem com uma defasagem, ou seja, o aumento no preço do açúcar cristal industrial no primeiro período causa aumento no preço do álcool anidro e no preço do açúcar cristal empacotado ao produtor no segundo período. Os choques praticamente desaparecem a partir do sexto mês.

Na Figura 11 constam os impactos de choque no preço do álcool anidro sobre ele mesmo e sobre os preços dos açúcares cristal exportado e industrial, os quais respondem no mesmo sentido apenas no quarto período. No entanto, as elasticidades são inexpressivas.

Um choque no preço do açúcar cristal exportado apresentou pequeno impacto sobre o preço do álcool anidro e sobre o preço do açúcar cristal industrial (Figura 12). Essa pequena influência do preço do mercado externo sobre o preço do mercado interno pode estar relacionada à assimetria do processo de transmissão de preços. Acréscimos de preços no mercado externo podem estar sendo repassados para os preços internos, mas decréscimos de preços no mercado externo não necessariamente são repassados para os preços dos produtos de mercado interno. Na Figura 3, do subcapítulo 2.2.3.1, podem ser visualizados períodos em que o preço do açúcar exportado apresentou queda enquanto o preço de mercado interno não mostrou esse comportamento. 
Tabela 9. Decomposição histórica da variância do erro de previsão para o preço do açúcar cristal industrial (Modelo 1).

\begin{tabular}{ccccccc}
\hline \multirow{2}{*}{ Mês } & & \multicolumn{2}{c}{ Decomposição da variância devida a choques (\%) } \\
\cline { 3 - 7 } & $\begin{array}{c}\text { Desvio- } \\
\text { padrão }\end{array}$ & $\begin{array}{c}\text { Cristal } \\
\text { indúst. }\end{array}$ & $\begin{array}{c}\text { Alcool } \\
\text { anidro }\end{array}$ & $\begin{array}{c}\text { Cristal } \\
\text { export. }\end{array}$ & $\begin{array}{c}\text { Cristal } \\
\text { empac. }\end{array}$ & $\begin{array}{c}\text { Empac. } \\
\text { varejo }\end{array}$ \\
\hline 1 & 0.069 & 100.000 & 0.000 & 0.000 & 0.000 & 0.000 \\
2 & 0.075 & 93.281 & 0.005 & 0.029 & 4.152 & 2.534 \\
3 & 0.076 & 92.338 & 0.075 & 0.441 & 4.136 & 3.010 \\
4 & 0.077 & 90.941 & 0.565 & 0.658 & 4.548 & 3.288 \\
5 & 0.077 & 90.413 & 0.558 & 0.744 & 5.035 & 3.250 \\
6 & 0.078 & 90.341 & 0.586 & 0.800 & 5.019 & 3.253 \\
7 & 0.078 & 90.302 & 0.587 & 0.817 & 5.049 & 3.245 \\
\hline
\end{tabular}

Fonte: Dados da pesquisa

Tabela 10. Decomposição histórica da variância do erro de previsão para o preço do álcool anidro (Modelo $1)$.

\begin{tabular}{|c|c|c|c|c|c|c|}
\hline \multirow[b]{2}{*}{ Mês } & \multirow[b]{2}{*}{$\begin{array}{c}\text { Desvio- } \\
\text { padrão }\end{array}$} & \multicolumn{5}{|c|}{ Decomposição da variância devida a choques (\%) } \\
\hline & & $\begin{array}{l}\text { Cristal } \\
\text { indúst. }\end{array}$ & $\begin{array}{l}\text { Álcool } \\
\text { anidro }\end{array}$ & $\begin{array}{l}\text { Cristal } \\
\text { export. }\end{array}$ & $\begin{array}{l}\text { Cristal } \\
\text { empac. }\end{array}$ & $\begin{array}{l}\text { Empac. } \\
\text { Varejo }\end{array}$ \\
\hline 1 & 0.032 & 0.015 & 99.985 & 0.000 & 0.000 & 0.000 \\
\hline 2 & 0.035 & 0.013 & 87.999 & 0.797 & 9.317 & 1.874 \\
\hline 3 & 0.046 & 20.094 & 60.079 & 4.214 & 13.421 & 2.192 \\
\hline 4 & 0.050 & 26.820 & 53.947 & 3.925 & 12.094 & 3.213 \\
\hline 5 & 0.051 & 25.972 & 53.644 & 3.900 & 12.072 & 4.412 \\
\hline 6 & 0.053 & 29.443 & 50.637 & 3.932 & 11.635 & 4.353 \\
\hline 7 & 0.053 & 29.241 & 50.270 & 4.383 & 11.766 & 4.340 \\
\hline
\end{tabular}

Fonte: Dados da pesquisa
Tabela 11. Decomposição histórica da variância do erro de previsão para o preço do açúcar cristal exportado (Modelo 1).

\begin{tabular}{|c|c|c|c|c|c|c|}
\hline \multirow[b]{2}{*}{ Mês } & \multirow[b]{2}{*}{$\begin{array}{c}\text { Desvio- } \\
\text { padrão }\end{array}$} & \multicolumn{5}{|c|}{ Decomposição da variância devida a choques (\%) } \\
\hline & & $\begin{array}{l}\text { Cristal } \\
\text { indúst. }\end{array}$ & $\begin{array}{l}\text { Álcool } \\
\text { anidro }\end{array}$ & $\begin{array}{l}\text { Cristal } \\
\text { export. }\end{array}$ & $\begin{array}{l}\text { Cristal } \\
\text { empac. }\end{array}$ & $\begin{array}{l}\text { Empac. } \\
\text { Varejo }\end{array}$ \\
\hline 1 & 0.074 & 3.904 & 0.000 & 96.096 & 0.000 & 0.000 \\
\hline 2 & 0.079 & 5.968 & 5.924 & 83.052 & 0.719 & 4.337 \\
\hline 3 & 0.097 & 22.401 & 5.480 & 55.507 & 13.246 & 3.367 \\
\hline 4 & 0.099 & 22.319 & 5.477 & 55.282 & 13.698 & 3.224 \\
\hline 5 & 0.101 & 22.765 & 5.362 & 54.578 & 13.979 & 3.316 \\
\hline 6 & 0.101 & 22.582 & 5.906 & 54.159 & 13.917 & 3.436 \\
\hline 7 & 0.101 & 22.591 & 5.900 & 54.157 & 13.917 & 3.435 \\
\hline
\end{tabular}

Tabela 12. Decomposição histórica da variância do erro de previsão para o preço do açúcar cristal empacotado ao produtor (Modelo 1).

\begin{tabular}{ccrrrrr}
\hline & & \multicolumn{2}{c}{ Decomposição da variância devida a choques (\%) } \\
\cline { 3 - 7 } Mês & $\begin{array}{c}\text { Desvio- } \\
\text { padrão }\end{array}$ & $\begin{array}{c}\text { Cristal } \\
\text { indúst. }\end{array}$ & $\begin{array}{c}\text { Alcool } \\
\text { anidro }\end{array}$ & $\begin{array}{c}\text { Cristal } \\
\text { export. }\end{array}$ & $\begin{array}{c}\text { Cristal } \\
\text { empac. }\end{array}$ & $\begin{array}{c}\text { Empac. } \\
\text { Varejo }\end{array}$ \\
\hline 1 & 0.037 & 0.000 & 0.000 & 0.000 & 100.000 & 0.000 \\
2 & 0.045 & 17.585 & 0.585 & 2.902 & 72.272 & 6.656 \\
3 & 0.049 & 24.641 & 0.549 & 3.867 & 65.239 & 5.704 \\
4 & 0.049 & 24.223 & 1.363 & 4.134 & 64.449 & 5.830 \\
5 & 0.049 & 24.135 & 1.505 & 4.174 & 64.357 & 5.830 \\
6 & 0.050 & 24.466 & 1.546 & 4.197 & 64.000 & 5.791 \\
7 & 0.050 & 24.455 & 1.545 & 4.250 & 63.963 & 5.788 \\
\hline
\end{tabular}

Fonte: Dados da pesquisa 
Na Figura 13, referente aos impactos nas variáveis devido a choque no preço do açúcar cristal empacotado ao produtor, observa-se que os preços dos açúcares cristal industrial e cristal empacotado ao varejo respondem positivamente ao choque com um período de defasagem, enquanto que o preço do açúcar cristal exportado responde positivamente ao choque apenas no quarto período seguinte ao choque. Observa-se, também, que os impactos sobre o preço do mercado varejista são positivos para todo o período. Alterações de preço decorrentes do choque são expressivas no início, mas praticamente desaparecem a partir do sétimo período.

Ao contrário do esperado, um choque no preço do açúcar cristal empacotado ao varejo causa impacto em sentido oposto nos preços do açúcar cristal industrial e do açúcar cristal empacotado ao produtor no segundo mês (Figura 14). Somente no terceiro mês, o impacto de uma variação no preço do açúcar cristal empacotado ao varejo sobre o preço do açúcar cristal industrial ocorre na mesma direção, sendo, no entanto, de pequena magnitude.

Dessa forma, os resultados apontam que as variáveis respondem mais eficientemente aos choques de preços dos produtos de mercado interno do que ao choque no preço de exportação. Os maiores efeitos ocorrem no caso de choques no preço do açúcar cristal industrial e o maior impacto sobre esse preço é oriundo de choque no preço do açúcar cristal empacotado ao produtor.

\subsubsection{Modelo 2: influência contemporânea do preço do álcool anidro sobre os preços do açúcar cristal exportado e do açúcar cristal industrial}

Outra alternativa considerada no ajustamento do modelo VEC foi a influência contemporânea do preço do álcool anidro sobre o preço do açúcar cristal industrial e sobre o preço recebido pela exportação do açúcar cristal. 
Tabela 13. Decomposição histórica da variância do erro de previsão para o preço do açúcar cristal empacotado ao varejo (Modelo 1).

Decomposição da variância devida a choques (\%)

\begin{tabular}{cccccrr}
\hline & & \multicolumn{5}{c}{ Decomposição da variância devida a choques (\%) } \\
\cline { 3 - 7 } Mês & $\begin{array}{c}\text { Desvio- } \\
\text { padrão }\end{array}$ & $\begin{array}{c}\text { Cristal } \\
\text { indúst. }\end{array}$ & $\begin{array}{c}\text { Álcool } \\
\text { anidro }\end{array}$ & $\begin{array}{r}\text { Cristal } \\
\text { export. }\end{array}$ & $\begin{array}{r}\text { Cristal } \\
\text { empac. }\end{array}$ & $\begin{array}{r}\text { Empac. } \\
\text { Varejo }\end{array}$ \\
\hline 1 & 0.022 & 0.000 & 0.000 & 0.000 & 0.000 & 100.000 \\
2 & 0.026 & 0.598 & 1.345 & 0.173 & 24.307 & 73.578 \\
3 & 0.028 & 3.407 & 3.333 & 0.192 & 29.141 & 63.927 \\
4 & 0.029 & 4.054 & 3.160 & 2.863 & 28.321 & 61.603 \\
5 & 0.029 & 5.141 & 4.220 & 3.028 & 27.490 & 60.120 \\
6 & 0.030 & 6.871 & 4.254 & 3.021 & 27.270 & 58.584 \\
7 & 0.030 & 7.153 & 4.307 & 3.218 & 27.084 & 58.239 \\
\hline
\end{tabular}

Fonte: Dados da pesquisa

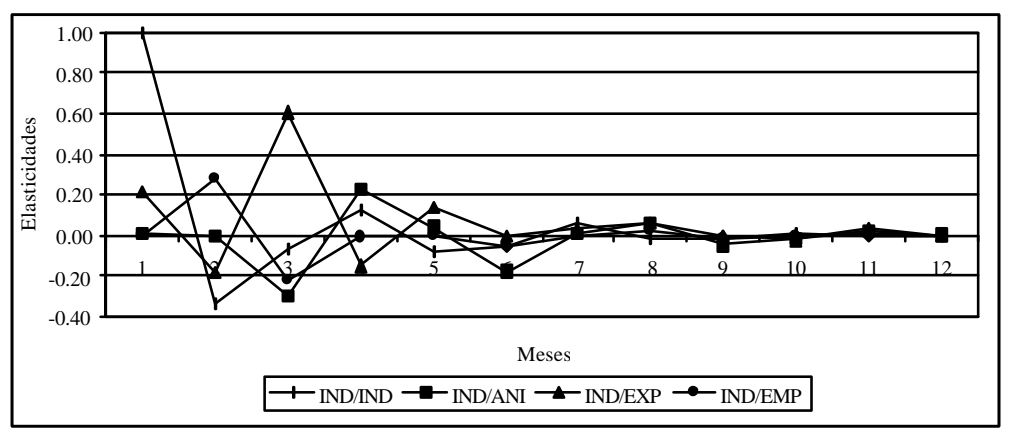

Figura 10 - Função de resposta dos preços do açúcar cristal industrial (ind), do álcool anidro (ani), do açúcar cristal exportado (exp) e do açúcar cristal empacotado ao produtor (emp), a impulso no preço do açúcar cristal industrial (Modelo 1).

Fonte: Dados da pesquisa

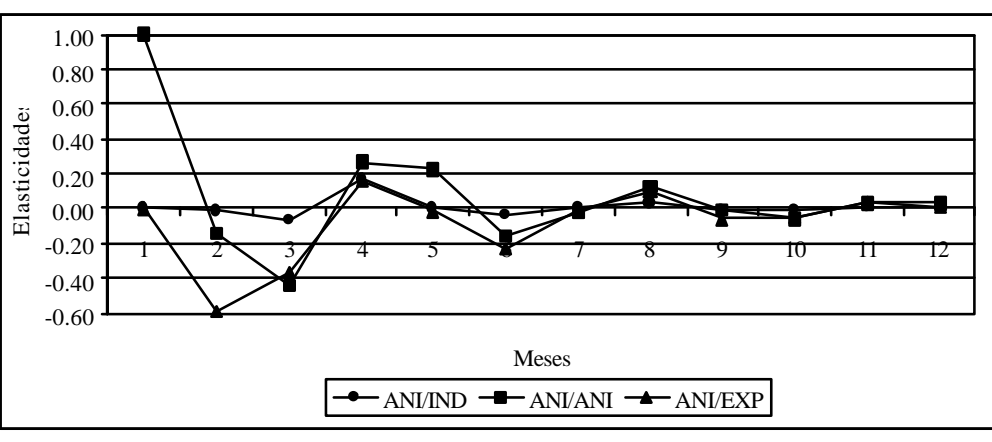

Figura 11 - Função de resposta dos preços do açúcar cristal industrial (ind), do álcool anidro (ani) e do açúcar cristal exportado (exp), a impulso no preço do álcool anidro (Modelo 1).

Fonte: Dados da pesquisa

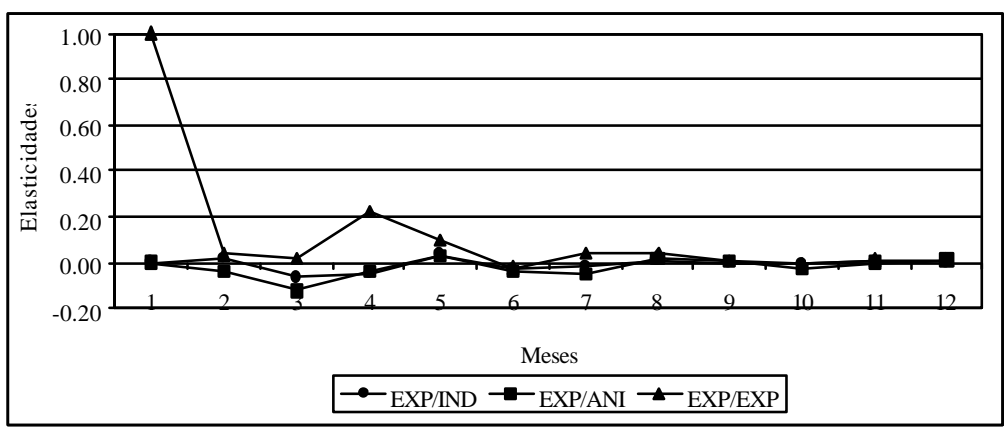

Figura 12 - Função de resposta dos preços do açúcar cristal industrial (ind), do álcool anidro (ani) e do açúcar cristal exportado (exp), a impulso no preço do açúcar cristal exportado (Modelo 1).

Fonte: Dados da pesquisa 


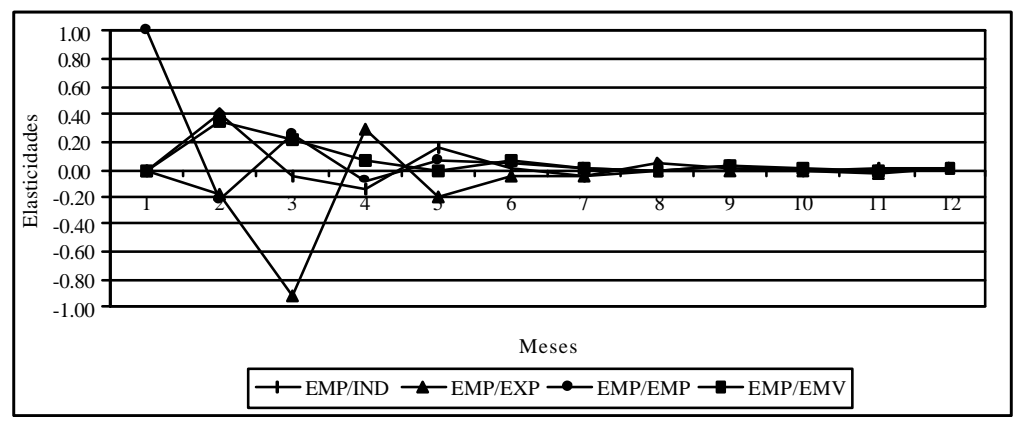

Figura 13 - Função de resposta dos preços dos açúcares cristal industrial (ind), do cristal exportado (exp) e do cristal empacotado ao produtor (emp) e ao varejo (emv), a impulso no preço do açúcar cristal empacotado ao produtor (Modelo 1).

Fonte: Dados da pesquisa

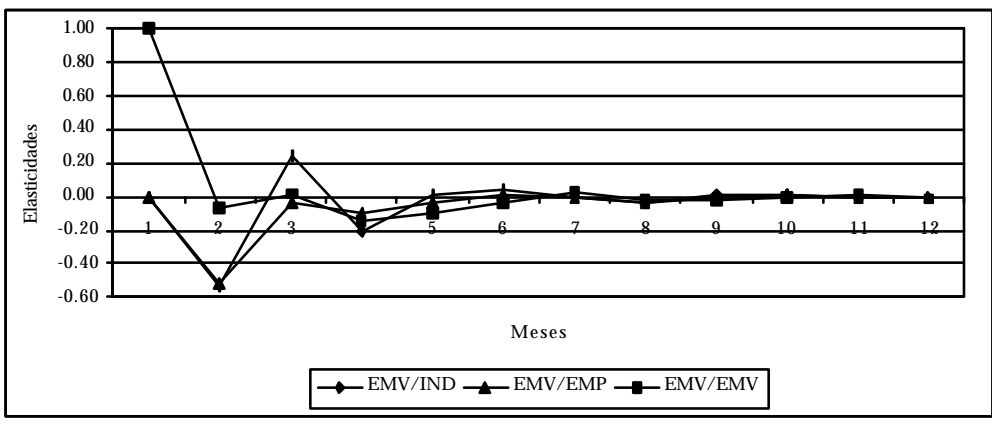

Figura 14 - Função de resposta dos preços do açúcar cristal industrial (ind) e do açúcar cristal empacotado ao produtor (emp) e ao varejo (emv), a impulso no preço do açúcar cristal empacotado ao varejo (Modelo 1).

Fonte: Dados da pesquisa 
A matriz estimada de coeficientes de relações contemporâneas apresentou os resultados mostrados na Tabela 14. O sinal do coeficiente da relação entre o preço do açúcar cristal industrial e o preço do álcool anidro (leiam-se: linha=lnind e coluna=lnani) está de acordo com o esperado, porém é não-significativo. O coeficiente da relação entre o açúcar cristal exportado e o álcool anidro apresentou sinal contrário ao esperado, mas também é não-significativo. Esses resultados mostram que alteração no preço do álcool anidro não causa impacto contemporâneo sobre os preços dos açúcares cristal industrial e exportado.

Tabela 14. Estimativa da matriz de coeficientes de relações contemporâneas (Modelo 2).

\begin{tabular}{|c|c|c|c|}
\hline \multicolumn{2}{|c|}{ Relações } & Coeficientes & Desvio-padrão \\
\hline Linha & Coluna & & \\
\hline lnind & lnani & $-0,0286$ & 0,311 \\
\hline lnexp & Inani & 0,1808 & 0,331 \\
\hline
\end{tabular}

Fonte: Dados da pesquisa

Os resultados obtidos no ajustamento desse modelo em relação à decomposição da variância dos erros de previsão e elasticidades de impulso-resposta (ANEXO B) são muito próximos daqueles obtidos no Modelo 1.

\subsubsection{Modelo 3: influência contemporânea do preço do açúcar cristal empacotado ao varejo sobre o preço do açúcar cristal empacotado ao produtor}

Considerou-se, também, no ajustamento do modelo VEC, a alternativa da influência contemporânea do preço do açúcar cristal empacotado ao varejo sobre o preço do açúcar cristal empacotado ao produtor.

O coeficiente da relação contemporânea apresentou o resultado mostrado na Tabela 15. O sinal do coeficiente da relação entre o preço do açúcar cristal empacotado ao produtor e o preço do açúcar cristal empacotado ao varejo (leiam-se: linha=lnemp e coluna=lnemv) está de acordo com o esperado e é significativo. Esse resultado mostra que aumento de $1 \%$ no preço do açúcar cristal empacotado ao varejo causa impacto 
contemporâneo, no mesmo sentido, de $0,57 \%$ sobre o preço do açúcar cristal empacotado ao produtor.

Tabela 15. Estimativa da matriz de coeficientes de relações contemporâneas (Modelo 3).

\begin{tabular}{ccccc}
\hline & Relação & & Coeficiente & Desvio-padrão \\
\cline { 1 - 2 } Linha & Coluna & & 0,229 \\
\hline lnemp & lnemv & $-0,5719$ & \\
\hline
\end{tabular}

Fonte: Dados da pesquisa

As decomposições das variâncias dos erros de previsão para esse modelo estão nas Tabelas 16 a 20. Observa-se na Tabela 16, na qual consta a decomposição da variância do erro de previsão para o preço do açúcar cristal industrial, que este se tornou sensivelmente mais autônomo em relação aos Modelos 1 e 2, uma vez que a própria variável passou a explicar $94,1 \%$ de suas variações. O preço do açúcar cristal empacotado ao produtor e ao varejo, média de 3,6\% e 1,4\% respectivamente, continuam sendo as variáveis que mais explicam as variações do preço de açúcar cristal industrial. Não se observou a influência dos preços do álcool anidro e do açúcar cristal exportado sobre o preço do açúcar cristal, da mesma forma que nos modelos anteriores.

$\mathrm{Na}$ decomposição para o preço do álcool anidro, os resultados mostram que própria variável explica, em média, 64,6\% de suas variações (Tabela 17). Das demais variáveis, os preços do açúcar cristal industrial e do cristal empacotado ao produtor e ao varejo (com médias de 16,7\%, 8,9\% e 6,7\%, respectivamente) são as que mais explicam o preço do álcool anidro, da mesma forma que no Modelo 1.

$\mathrm{Na}$ decomposição da variância do erro de previsão do preço do açúcar cristal exportado (Tabela 18), observa-se que a própria variável explica a maior parte de suas variações, seguida da parcela explicada pelo preço do açúcar cristal industrial (médias de $68,2 \%$ e $15,7 \%$, respectivamente). Os preços do açúcar cristal empacotado ao produtor e do álcool anidro, com médias de $9 \%$ e $5 \%$, respectivamente, apresentaram menores influências sobre o preço de exportação.

A decomposição da variância do erro de previsão do preço do açúcar cristal empacotado ao produtor consta na Tabela 19. A própria variável explica $60,4 \%$ de suas variações, enquanto o preço do mercado varejista explica 15,2\%. Para o mercado 
varejista, observa-se (Tabela 20) que a própria variável explica 70,2\% de suas variações, enquanto o preço do mercado produtor do açúcar cristal empacotado explica $21 \%$ (Tabela 20).

Ao analisar os impactos que cada variável causa, nos doze períodos seguintes, sobre si mesma e nas demais, quando sofre um choque, observa-se nas Figuras 15 a 19 que não há alteração em relação aos Modelos 1 e 2 apresentados, com exceção dos impactos causados pelo choque no preço do açúcar cristal empacotado ao varejo. Os impactos do choque no preço do açúcar cristal industrial (Figura 15) sobre os preços do açúcar cristal empacotado ao produtor e do álcool anidro ocorrem com um período de defasagem, enquanto que o impacto sobre o preço do açúcar cristal exportado se dá somente no terceiro mês.

O choque no preço do álcool anidro começa a afetar os preços dos açúcares cristal exportado e industrial apenas a partir do quarto mês (Figura 16). Impactos de choque no preço do açúcar cristal exportado sobre os preços do álcool anidro e do açúcar cristal industrial (Figura 17) continuaram sendo pequenos para todo o período sob análise. Da mesma maneira, choque no preço do açúcar cristal empacotado ao produtor (Figura 18) impacta os preços dos açúcares cristal industrial e cristal empacotado ao varejo com um período de defasagem, enquanto que o preço do açúcar cristal exportado responde positivamente ao choque apenas no quarto período seguinte.

O choque no preço do mercado varejista, por sua vez, tem influência sobre os preços dos açúcares cristal industrial e empacotado ao produtor (Figura 19). Destaca-se a expressiva elasticidade em relação ao preço do açúcar cristal empacotado ao produtor no primeiro período, assim como valor positivo no terceiro período, apesar de ser de menor magnitude. O preço do açúcar cristal industrial responde positivamente somente no terceiro período. Os preços ao produtor, para os segmentos industrial e empacotado, são afetados até que o preço ao varejo esteja sob influência do próprio choque. 
Tabela 16. Decomposição histórica da variância do erro de previsão para o preço do açúcar cristal industrial (Modelo 3).

\begin{tabular}{ccccccc}
\hline \multicolumn{1}{c}{ Decomposição da variância devida a choques (\%) } \\
\cline { 3 - 7 } Mês & $\begin{array}{c}\text { Desvio- } \\
\text { padrão }\end{array}$ & $\begin{array}{c}\text { Cristal } \\
\text { indúst. }\end{array}$ & $\begin{array}{c}\text { Alcool } \\
\text { anidro }\end{array}$ & $\begin{array}{c}\text { Cristal } \\
\text { export. }\end{array}$ & $\begin{array}{c}\text { Cristal } \\
\text { empac. }\end{array}$ & $\begin{array}{c}\text { Empac. } \\
\text { varejo }\end{array}$ \\
\hline 1 & 0.069 & 100.000 & 0.000 & 0.000 & 0.000 & 0.000 \\
2 & 0.075 & 95.378 & 0.004 & 0.030 & 3.762 & 0.825 \\
3 & 0.075 & 94.461 & 0.078 & 0.464 & 3.754 & 1.243 \\
4 & 0.076 & 92.684 & 0.579 & 0.691 & 4.110 & 1.936 \\
5 & 0.077 & 92.119 & 0.571 & 0.781 & 4.541 & 1.987 \\
6 & 0.077 & 92.036 & 0.600 & 0.840 & 4.528 & 1.996 \\
7 & 0.077 & 91.986 & 0.600 & 0.857 & 4.555 & 2.002 \\
\hline
\end{tabular}

Fonte: Dados da pesquisa

Tabela 17. Decomposição histórica da variância do erro de previsão para o preço do álcool anidro (Modelo 3).

\begin{tabular}{ccrrrrr}
\hline \multirow{2}{*}{ Mês } & & \multicolumn{6}{c}{ Decomposição da variância devida a choques (\%) } \\
\cline { 3 - 7 } & $\begin{array}{c}\text { Desvio- } \\
\text { padrão }\end{array}$ & $\begin{array}{c}\text { Cristal } \\
\text { indúst. }\end{array}$ & $\begin{array}{r}\text { Alcool } \\
\text { anidro }\end{array}$ & $\begin{array}{c}\text { Cristal } \\
\text { export. }\end{array}$ & $\begin{array}{r}\text { Cristal } \\
\text { empac. }\end{array}$ & $\begin{array}{c}\text { Empac. } \\
\text { Varejo }\end{array}$ \\
\hline 1 & 0.032 & 0.000 & 100.000 & 0.000 & 0.000 & 0.000 \\
2 & 0.035 & 0.025 & 85.412 & 0.791 & 8.236 & 5.536 \\
3 & 0.046 & 16.417 & 59.974 & 4.327 & 11.924 & 7.358 \\
4 & 0.050 & 24.020 & 53.130 & 3.991 & 10.637 & 8.221 \\
5 & 0.051 & 23.351 & 53.210 & 3.994 & 10.688 & 8.757 \\
6 & 0.053 & 26.559 & 50.374 & 4.029 & 10.348 & 8.690 \\
7 & 0.054 & 26.432 & 49.986 & 4.496 & 10.467 & 8.619 \\
\hline
\end{tabular}

Fonte: Dados da pesquisa
Tabela 18. Decomposição histórica da variância do erro de previsão para o preço do açúcar cristal exportado (Modelo 3).

\begin{tabular}{ccrcrrr}
\hline \multirow{2}{*}{ Mês } & Desvio- & \multicolumn{2}{c}{ Decomposição da variância devida a choques (\%) } \\
\cline { 3 - 7 } & padrão & $\begin{array}{c}\text { Cristal } \\
\text { indúst. }\end{array}$ & $\begin{array}{l}\text { Álcool } \\
\text { anidro }\end{array}$ & $\begin{array}{r}\text { Cristal } \\
\text { export. }\end{array}$ & $\begin{array}{r}\text { Cristal } \\
\text { empac. }\end{array}$ & $\begin{array}{c}\text { Empac. } \\
\text { Varejo }\end{array}$ \\
\hline 1 & 0.074 & 0.000 & 0.000 & 100.000 & 0.000 & 0.000 \\
2 & 0.079 & 2.815 & 6.000 & 87.344 & 0.615 & 3.226 \\
3 & 0.096 & 20.707 & 5.637 & 59.110 & 12.075 & 2.471 \\
4 & 0.099 & 21.361 & 5.590 & 58.349 & 12.343 & 2.356 \\
5 & 0.100 & 21.675 & 5.496 & 57.861 & 12.632 & 2.336 \\
6 & 0.100 & 21.507 & 6.062 & 57.437 & 12.579 & 2.415 \\
7 & 0.100 & 21.505 & 6.057 & 57.443 & 12.583 & 2.413 \\
\hline Fonte:
\end{tabular}

Fonte: Dados da pesquisa

Tabela 19. Decomposição histórica da variância do erro de previsão para o preço do açúcar cristal empacotado ao produtor (Modelo 3).

\begin{tabular}{|c|c|c|c|c|c|c|}
\hline \multirow[b]{2}{*}{ Mês } & \multirow[b]{2}{*}{$\begin{array}{c}\text { Desvio- } \\
\text { padrão }\end{array}$} & \multicolumn{5}{|c|}{ Decomposição da variância devida a choques (\%) } \\
\hline & & $\begin{array}{l}\text { Cristal } \\
\text { indúst. }\end{array}$ & $\begin{array}{l}\text { Álcool } \\
\text { anidro }\end{array}$ & $\begin{array}{l}\text { Cristal } \\
\text { export. }\end{array}$ & $\begin{array}{l}\text { Cristal } \\
\text { empac. }\end{array}$ & $\begin{array}{l}\text { Empac. } \\
\text { Varejo }\end{array}$ \\
\hline 1 & 0.037 & 0.000 & 0.000 & 0.000 & 88.319 & 11.681 \\
\hline 2 & 0.046 & 19.117 & 0.556 & 2.845 & 60.077 & 17.405 \\
\hline 3 & 0.050 & 24.621 & 0.536 & 3.878 & 55.567 & 15.398 \\
\hline 4 & 0.050 & 24.150 & 1.323 & 4.144 & 54.825 & 15.558 \\
\hline 5 & 0.050 & 24.069 & 1.463 & 4.185 & 54.778 & 15.504 \\
\hline 6 & 0.050 & 24.346 & 1.505 & 4.210 & 54.515 & 15.424 \\
\hline 7 & 0.051 & 24.332 & 1.504 & 4.264 & 54.484 & 15.415 \\
\hline
\end{tabular}

Fonte: Dados da pesquisa 
Tabela 20. Decomposição histórica da variância do erro de previsão para o preço do açúcar cristal empacotado ao varejo (Modelo 3).

Decomposição da variância devida a choques (\%)

\begin{tabular}{cccccrr}
\hline & & \multicolumn{3}{c}{ Decomposição da variância devida a choques (\%) } \\
\cline { 3 - 7 } Mês & $\begin{array}{c}\text { Desvio- } \\
\text { padrão }\end{array}$ & $\begin{array}{c}\text { Cristal } \\
\text { indúst. }\end{array}$ & $\begin{array}{c}\text { Álcool } \\
\text { anidro }\end{array}$ & $\begin{array}{r}\text { Cristal } \\
\text { export. }\end{array}$ & $\begin{array}{r}\text { Cristal } \\
\text { empac. }\end{array}$ & $\begin{array}{r}\text { Empac. } \\
\text { Varejo }\end{array}$ \\
\hline 1 & 0.022 & 0.000 & 0.000 & 0.000 & 0.000 & 100.000 \\
2 & 0.026 & 0.717 & 1.375 & 0.182 & 21.815 & 75.912 \\
3 & 0.028 & 3.678 & 3.373 & 0.200 & 26.065 & 66.685 \\
4 & 0.029 & 3.866 & 3.229 & 3.030 & 25.581 & 64.294 \\
5 & 0.029 & 5.175 & 4.296 & 3.194 & 24.721 & 62.613 \\
6 & 0.029 & 6.810 & 4.345 & 3.194 & 24.593 & 61.058 \\
7 & 0.030 & 7.006 & 4.404 & 3.401 & 24.442 & 60.747 \\
\hline
\end{tabular}

Fonte: Dados da pesquisa

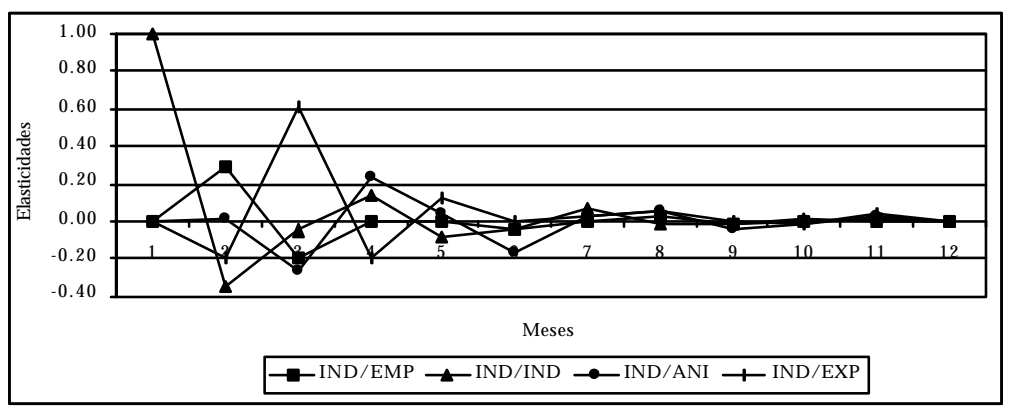

Figura 15 - Função de resposta dos preços do açúcar cristal industrial (ind), do álcool anidro (ani), do açúcar cristal exportado (exp) e do açúcar cristal empacotado ao produtor (emp), a impulso no preço do açúcar cristal industrial (Modelo 3).

Fonte: Dados da pesquisa

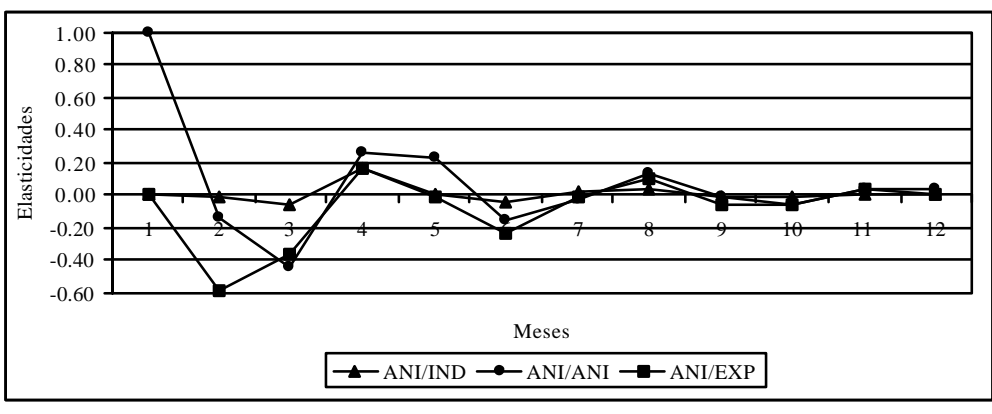

Figura 16 - Função de resposta dos preços do açúcar cristal industrial (ind), do álcool anidro (ani) e do açúcar cristal exportado (exp), a impulso no preço do álcool anidro (Modelo 3).

Fonte: Dados da pesquisa

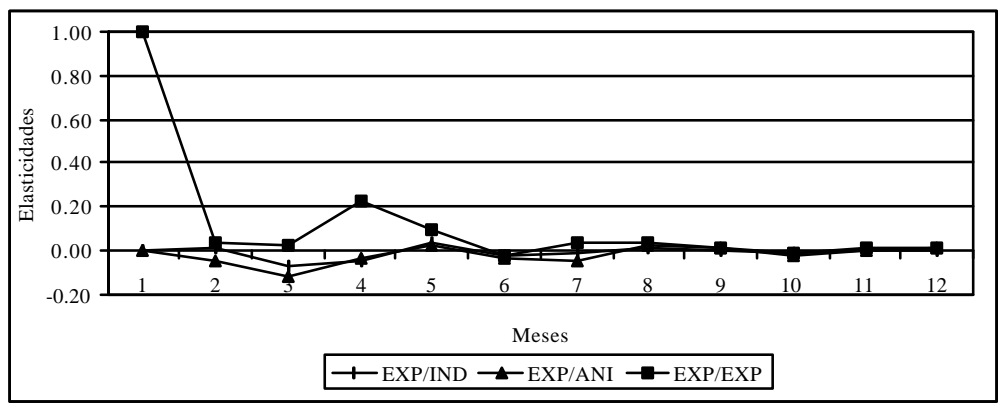

Figura 17 - Função de resposta dos preços do açúcar cristal industrial (ind), do álcool anidro (ani) e do açúcar cristal exportado (exp), a impulso no preço do açúcar cristal exportado (Modelo 3).

Fonte: Dados da pesquisa 


\subsubsection{Modelo 4: influência contemporânea do preço do açúcar cristal exportado sobre o preço do açúcar cristal industrial}

A última alternativa considerada foi aquela na qual se especificou a influência do preço do açúcar cristal exportado sobre o preço do açúcar cristal industrial na matriz de relações contemporâneas. O sinal do coeficiente da relação entre o preço do açúcar cristal industrial e o preço do açúcar cristal exportado (leiam-se: linha=lnind e coluna=lnexp) está de acordo com o esperado e significativo. Esse resultado mostra que alteração de $1 \%$ no preço do açúcar cristal exportado causa impacto contemporâneo, no mesmo sentido, de 0,26\% sobre o preço do açúcar cristal industrial (Tabela 21).

Tabela 21. Estimativa da matriz de coeficientes de relações contemporâneas (Modelo 4).

\begin{tabular}{ccccc}
\hline & Relação & & Coeficiente & Desvio-padrão \\
\cline { 1 - 2 } Linha & Coluna & & 0,120 \\
\hline lnind & $\operatorname{lnexp}$ & $-0,2574$ & \\
\hline
\end{tabular}

Fonte: Dados da pesquisa

As decomposições das variâncias dos erros de previsão para esse modelo constam nas Tabelas 22 a 26. Observa-se, na Tabela 22, que a decomposição da variância do erro de previsão do açúcar cristal industrial mostrou maior dependência das demais variáveis do que as apresentadas nos modelos anteriores, sendo que o preço do açúcar cristal empacotado ao produtor continua sendo a que tem a maior parcela de explicação daquele preço dentre as demais. A própria variável explica, em média, 75\% da variância dos erros de previsão, seguida das parcelas explicadas pelos preços do açúcar cristal empacotado ao produtor $(13,3 \%)$ e do açúcar cristal exportado (7\%). As parcelas explicadas pelas demais variáveis são menos expressivas.

O preço do álcool anidro também se tornou mais dependente das demais variáveis em relação aos modelos anteriores, sendo que ele mesmo explica 52,8\% da própria variância do erro de previsão (Tabela 23). A variável que apresentou acréscimos na parcela de explicação do preço do álcool anidro foi o preço do açúcar cristal empacotado ao produtor, cuja participação média foi de 32,9\%. Em seguida, estão as parcelas de explicação devidas aos preços do açúcar cristal industrial (9,5\%), do açúcar 
cristal exportado $(3,1 \%)$ e do açúcar cristal empacotado ao varejo (1,7\%). Destacam-se as parcelas explicadas pelos preços dos açúcares cristal empacotado ao produtor e do industrial nos últimos períodos, as quais são mais de 38\% e 15\%, respectivamente.

O preço de exportação tornou-se mais independente das variáveis de mercado interno. A maior parte da variância do erro de previsão dessa variável (média de 72,5\%) é explicada por ela mesma, especialmente nos primeiros meses (Tabela 24). A parcela de explicação devida ao preço do açúcar cristal empacotado ao produtor correspondeu à média de $12 \%$, seguida pelas parcelas explicadas pelos preços do açúcar cristal industrial e do álcool anidro, as quais correspondem às médias de 8,8\% e 6,3\%, respectivamente.

Em relação ao preço do açúcar cristal empacotado ao produtor (Tabela 25), a decomposição da variância do erro de previsão mostra a dependência dessa variável dos preços do açúcar cristal industrial e do açúcar cristal empacotado ao varejo. A própria variável explica, em média, $69 \%$ da variância de seus erros de previsão; o preço do açúcar cristal industrial explica, em média, 16,5\%; o preço do açúcar cristal empacotado ao varejo explica 10,3\%; os preços do açúcar cristal exportado e do álcool anidro têm menos influência sobre o preço do açúcar cristal empacotado ao produtor (médias de $2,3 \%$ e do $1,9 \%$, respectivamente).

Para o mercado varejista do açúcar cristal empacotado, observa-se uma maior parcela de explicação do preço do mercado produtor do açúcar cristal empacotado (média de 37,3\%), comparado com os modelos anteriores. Entretanto, a própria variável e o seu mercado produtor explicam juntas o mesmo percentual das variações do preço do mercado varejista que nos modelos anteriores, ou seja, mais de 91\% (Tabela 26).

Nas Figuras 20 a 24 constam os impactos que cada variável causa, nos períodos seguintes, sobre si mesma e nas demais variáveis do modelo. Observa-se na Figura 20 que os impactos nas variáveis devido a choque no preço do açúcar cristal industrial são semelhantes aos obtidos nos modelos anteriores, no que diz respeito aos sinais. Entretanto, os impactos sobre os preços do açúcar cristal empacotado e do álcool anidro são sensivelmente maiores no segundo mês e o impacto sobre o preço de exportação é um pouco menor no terceiro período (esses são os períodos em que essas variáveis respondem ao choque). 


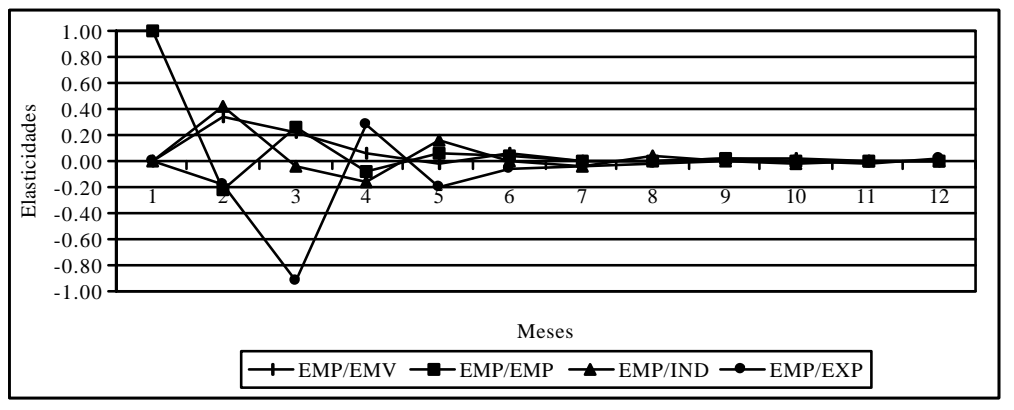

Figura 18 - Função de resposta dos preços dos açúcares cristal industrial (ind), do cristal exportado (exp) e do cristal empacotado ao produtor (emp) e ao varejo (emv), a impulso no preço do açúcar cristal empacotado ao produtor (Modelo $3)$.

Fonte: Dados da pesquisa

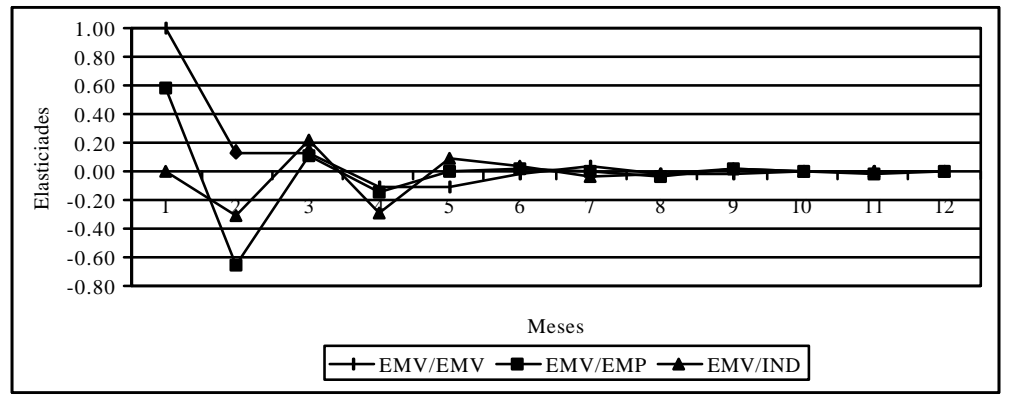

Figura 19 - Função de resposta dos preços do açúcar cristal industrial (ind) e do açúcar cristal empacotado ao produtor e ao varejo, a impulso no preço do açúcar cristal empacotado ao varejo (Modelo $3)$.

Fonte: Dados da pesquisa
Tabela 22. Decomposição histórica da variância do erro de previsão para o preço do açúcar cristal industrial (Modelo 4).

\begin{tabular}{cccccrc}
\hline \multicolumn{10}{c}{ Mês } & $\begin{array}{c}\text { Desvio-- } \\
\text { padrão }\end{array}$ & $\begin{array}{c}\text { Cristal } \\
\text { indúst. }\end{array}$ & $\begin{array}{c}\text { Álcool } \\
\text { anidro }\end{array}$ & $\begin{array}{c}\text { Cristal } \\
\text { export. }\end{array}$ & $\begin{array}{r}\text { Cristal } \\
\text { empac. }\end{array}$ & $\begin{array}{c}\text { Empac. } \\
\text { varejo }\end{array}$ \\
\hline 1 & 0.071 & 91.051 & 0.000 & 8.949 & 0.000 & 0.000 \\
2 & 0.083 & 74.222 & 0.034 & 6.657 & 14.167 & 4.921 \\
3 & 0.084 & 73.013 & 0.107 & 6.598 & 15.453 & 4.828 \\
4 & 0.085 & 71.686 & 0.642 & 6.724 & 15.774 & 5.174 \\
5 & 0.086 & 71.623 & 0.659 & 6.714 & 15.869 & 5.134 \\
6 & 0.086 & 71.632 & 0.664 & 6.759 & 15.832 & 5.113 \\
7 & 0.086 & 71.643 & 0.663 & 6.758 & 15.828 & 5.108 \\
\hline
\end{tabular}

Fonte: Dados da pesquisa

Tabela 23. Decomposição histórica da variância do erro de previsão para o preço do álcool anidro (Modelo 4).

\begin{tabular}{rrrrrrr}
\hline & & \multicolumn{6}{c}{ Decomposição da variância devida a choques (\%) } \\
\cline { 3 - 7 } Mês & $\begin{array}{c}\text { Desvio- } \\
\text { padrão }\end{array}$ & $\begin{array}{r}\text { Cristal } \\
\text { indúst. }\end{array}$ & \multicolumn{1}{c}{$\begin{array}{c}\text { Alcool } \\
\text { anidro }\end{array}$} & $\begin{array}{r}\text { Cristal } \\
\text { export. }\end{array}$ & $\begin{array}{r}\text { Cristal } \\
\text { empac. }\end{array}$ & $\begin{array}{c}\text { Empac. } \\
\text { Varejo }\end{array}$ \\
\hline 1 & 0.044 & 0.000 & 100.000 & 0.000 & 0.000 & 0.000 \\
2 & 0.056 & 0.501 & 62.544 & 1.268 & 33.784 & 1.903 \\
3 & 0.072 & 9.028 & 44.531 & 3.899 & 41.035 & 1.506 \\
4 & 0.077 & 13.187 & 40.968 & 4.318 & 39.664 & 1.863 \\
5 & 0.078 & 12.827 & 42.318 & 4.173 & 38.336 & 2.347 \\
6 & 0.081 & 15.389 & 39.761 & 3.966 & 38.686 & 2.199 \\
7 & 0.081 & 15.319 & 39.724 & 4.256 & 38.506 & 2.195 \\
\hline
\end{tabular}

Fonte: Dados da pesquisa 
Da mesma forma, o choque no preço do álcool anidro não causa impactos muito diferentes dos modelos anteriores (Figura 21). Pode-se apenas destacar que o impacto sobre o preço do açúcar cristal industrial ocorre com um período de defasagem, apesar da elasticidade ser inexpressiva, ao contrário do que vinha ocorrendo nos modelos anteriores, nos quais a resposta ocorria somente no quarto período.

De acordo com a Figura 22, o choque no preço do açúcar cristal exportado causa impacto no primeiro período no preço do açúcar cristal industrial. Sobre o preço do álcool anidro, o impacto ocorre com um período de defasagem. A partir do quinto período, os impactos do choque sobre as variáveis são aproximadamente nulos.

Resultados semelhantes aos obtidos nos modelos anteriores foram observados no caso de choque no preço do açúcar cristal empacotado ao produtor e do açúcar cristal empacotado ao varejo (Figuras 23 e 24)

Diante dos resultados encontrados nos quatro modelos apresentados, pode-se destacar alguns que ratificam os obtidos por Costa (2000), considerando um período mais recente de desregulamentação. Citam-se os coeficientes não-significativos das relações contemporâneas entre o açúcar cristal industrial e o álcool anidro, nos Modelos 1 e 2. Da mesma maneira, os resultados são semelhantes para a relação entre os preços do açúcar cristal empacotado ao produtor e ao varejo. Entretanto, essa autora havia observado em seu estudo que o preço externo não influenciava o mercado interno do açúcar cristal industrial. Os resultados aqui encontrados mostraram que contemporaneamente há relação entre esses preços.

Tentou-se implementar um modelo incluindo todas as relações que se mostraram significativas nos modelos apresentados, mas não foi possível sua estimação devido à não-convergência. Entretanto, acredita-se que a estabilidade dos resultados apresentada nos modelos analisados possibilita fazer inferências sobre o processo de transmissões de preços entre produtos do setor sucroalcooleiro do Estado de São Paulo. 
Tabela 24. Decomposição histórica da variância do erro de previsão para o preço do açúcar cristal exportado (Modelo 4).

\begin{tabular}{rrrrrrr}
\multicolumn{10}{c}{ Mês } & $\begin{array}{c}\text { Desvio- } \\
\text { padrão }\end{array}$ & $\begin{array}{c}\text { Cristal } \\
\text { indúst. }\end{array}$ & $\begin{array}{c}\text { Álcool } \\
\text { anidro }\end{array}$ & $\begin{array}{c}\text { Cristal } \\
\text { export. }\end{array}$ & $\begin{array}{c}\text { Cristal } \\
\text { empac. }\end{array}$ & $\begin{array}{c}\text { Empac. } \\
\text { Varejo }\end{array}$ \\
\hline 1 & 0.083 & 0.000 & 0.000 & 100.000 & 0.000 & 0.000 \\
2 & 0.088 & 0.943 & 5.836 & 89.249 & 3.971 & 0.001 \\
3 & 0.103 & 11.708 & 7.490 & 66.368 & 14.290 & 0.144 \\
4 & 0.105 & 12.189 & 7.522 & 64.284 & 15.619 & 0.386 \\
5 & 0.107 & 12.124 & 7.427 & 63.231 & 16.553 & 0.664 \\
6 & 0.107 & 12.228 & 7.967 & 62.386 & 16.636 & 0.783 \\
7 & 0.108 & 12.281 & 8.168 & 62.043 & 16.676 & 0.833 \\
\hline
\end{tabular}

Fonte: Dados da pesquisa

Tabela 25. Decomposição histórica da variância do erro de previsão para o preço do açúcar cristal empacotado ao produtor (Modelo 4).

\begin{tabular}{ccrccrr}
\hline & & \multicolumn{5}{c}{ Decomposição da variância devida a choques (\%) } \\
\cline { 3 - 7 } Mês & $\begin{array}{c}\text { Desvio- } \\
\text { padrão }\end{array}$ & $\begin{array}{c}\text { Cristal } \\
\text { indúst. }\end{array}$ & $\begin{array}{c}\text { Alcool } \\
\text { anidro }\end{array}$ & $\begin{array}{c}\text { Cristal } \\
\text { export. }\end{array}$ & $\begin{array}{r}\text { Cristal } \\
\text { empac. }\end{array}$ & $\begin{array}{r}\text { Empac. } \\
\text { Varejo }\end{array}$ \\
\hline 1 & 0.044 & 0.000 & 0.000 & 0.000 & 100.000 & 0.000 \\
2 & 0.054 & 17.390 & 1.912 & 0.889 & 66.010 & 13.799 \\
3 & 0.062 & 19.843 & 1.504 & 2.105 & 65.001 & 11.547 \\
4 & 0.063 & 19.400 & 2.314 & 2.895 & 63.578 & 11.812 \\
5 & 0.063 & 19.296 & 2.628 & 3.320 & 63.027 & 11.729 \\
6 & 0.064 & 19.611 & 2.624 & 3.403 & 62.707 & 11.656 \\
7 & 0.064 & 19.612 & 2.621 & 3.479 & 62.646 & 11.641 \\
\hline \multicolumn{7}{l}{ Fonte: Dados da pesquisa } \\
\end{tabular}

Fonte: Dados da pesquisa
Tabela 26. Decomposição histórica da variância do erro de previsão para o preço do açúcar cristal empacotado ao varejo (Modelo 4).

\begin{tabular}{cccccrc}
\hline \multirow{2}{*}{ Mês } & \multicolumn{7}{c}{$\begin{array}{c}\text { Desvio- } \\
\text { padrão }\end{array}$} & $\begin{array}{c}\text { Cristal } \\
\text { indúst. }\end{array}$ & $\begin{array}{c}\text { Álcool } \\
\text { anidro }\end{array}$ & $\begin{array}{c}\text { Cristal } \\
\text { export. }\end{array}$ & $\begin{array}{r}\text { Cristal } \\
\text { empac. }\end{array}$ & $\begin{array}{c}\text { Empac. } \\
\text { Varejo }\end{array}$ \\
\hline 1 & 0.022 & 0.000 & 0.000 & 0.000 & 0.000 & 100.000 \\
2 & 0.027 & 0.769 & 2.638 & 0.438 & 29.916 & 66.240 \\
3 & 0.033 & 2.900 & 3.358 & 1.349 & 46.994 & 45.398 \\
4 & 0.035 & 2.871 & 3.110 & 2.432 & 47.953 & 43.634 \\
5 & 0.036 & 3.772 & 4.443 & 2.631 & 46.112 & 43.042 \\
6 & 0.036 & 4.745 & 4.713 & 3.119 & 45.354 & 42.069 \\
7 & 0.036 & 5.145 & 4.669 & 3.408 & 45.106 & 41.672 \\
\hline \multicolumn{7}{l}{ Fonte: Dados da pesquisa }
\end{tabular}

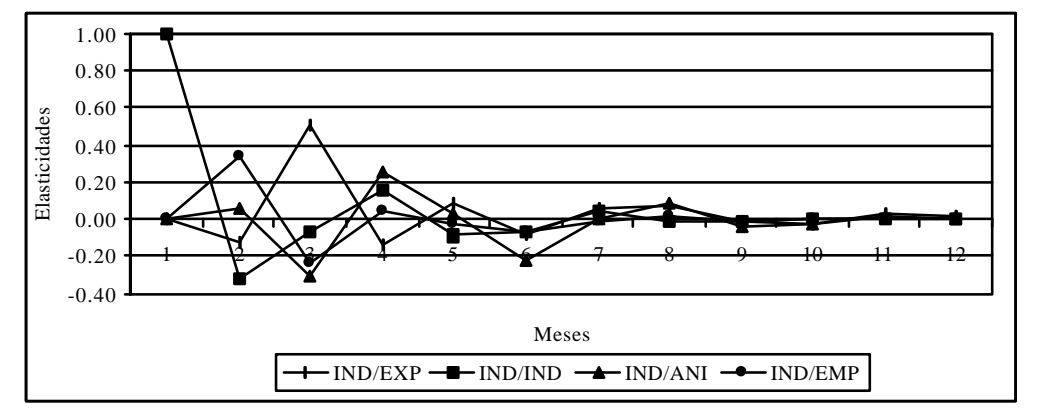

Figura 20 - Função de resposta dos preços do açúcar cristal industrial (ind), do álcool anidro (ani), do açúcar cristal exportado (exp) e do açúcar cristal empacotado ao produtor (emp), a impulso no preço do açúcar cristal industrial (Modelo 4).

Fonte: Dados da pesquisa 


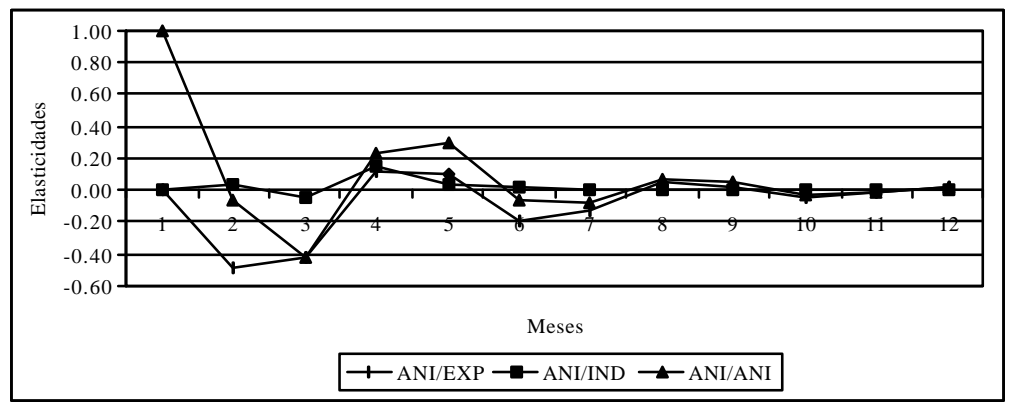

Figura 21 - Função de resposta dos preços do açúcar cristal industrial (ind), do álcool anidro (ani) e do açúcar cristal exportado (exp), a impulso no preço do álcool anidro (Modelo 4).

Fonte: Dados da pesquisa

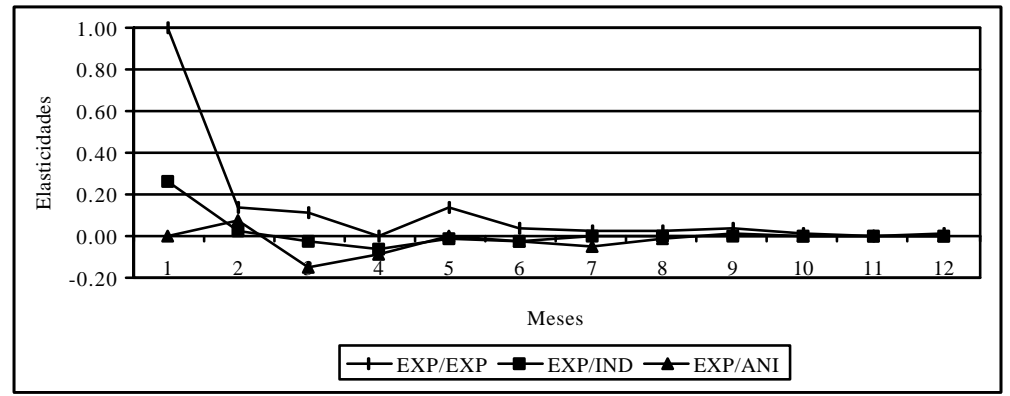

Figura 22 - Função de resposta dos preços do açúcar cristal industrial (ind), do álcool anidro (ani) e do açúcar cristal exportado (exp), a impulso no preço do açúcar cristal exportado (Modelo 4).

Fonte: Dados da pesquis a

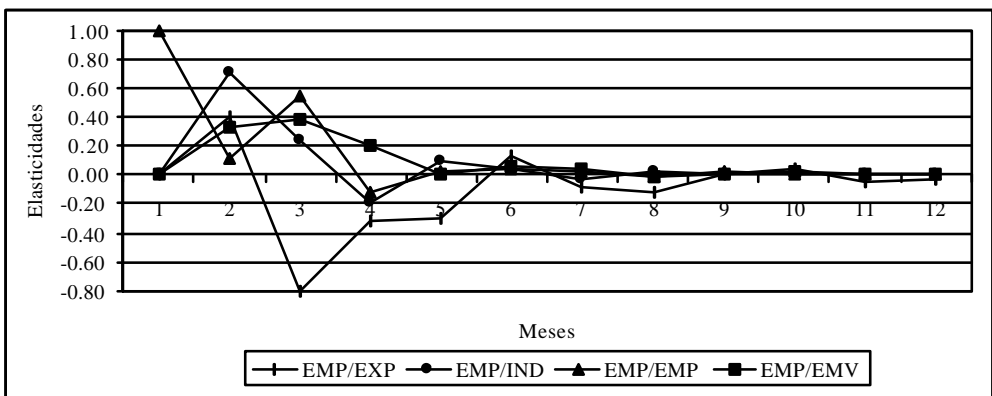

Figura 23 - Função de resposta dos preços dos açúcares cristal industrial (ind), do cristal exportado (exp) e do açúcar empacotado ao produtor (emp) e ao varejo (emv), a impulso no preço do açúcar cristal empacotado ao produtor (Modelo 4).

Fonte: Dados da pesquisa

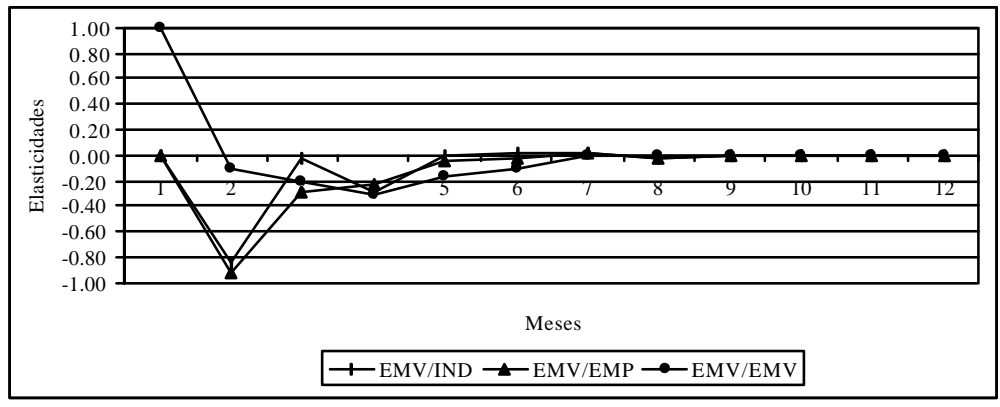

Figura 24 - Função de resposta dos preços do açúcar cristal industrial (ind) e do açúcar cristal empacotado ao produtor (emp) e ao varejo (emv), a impulso no preço do açúcar cristal empacotado ao varejo (Modelo 4).

Fonte: Dados da pesquisa 


\section{CONCLUSÕES}

Neste trabalho buscou-se analisar a transmissão de preços entre os mercados dos principais produtos do setor sucroalcooleiro do Estado de São Paulo. Determinou-se a intensidade e a duração em que as oscilações de preços são transmitidas de um nível de mercado para outro e de um produto para outro do mesmo nível de mercado. A análise compreendeu o período de maio de 1998 a junho de 2002.

As variáveis utilizadas na presente pesquisa foram: preço do álcool anidro, preço do açúcar cristal industrial, preço do açúcar cristal exportado e preço do açúcar cristal empacotado ao produtor e ao varejo. Não foram utilizados os preços do açúcar refinado e do álcool hidratado, em função da simplificação do modelo tendo em vista o número reduzido de dados na amostra e por não haver séries temporais disponíveis do preço do álcool hidratado para o período sob análise, uma vez que esse preço só foi liberado em 1999.

O modelo proposto para analisar as inter-relações de preços no setor sucroalcooleiro do Estado de São Paulo foi implementado através de testes de raiz unitária de Dickey-Fuller Aumentado (ADF), de co-integração de Johansen e método de Auto-Regressão Vetorial com Correção de Erro (VEC). Dada a impossibilidade de definir a priori quais as inter-relações que ocorrem contemporaneamente, testaram-se as seguintes alternativas para estabelecer a matriz que trata dessas relações: a) variação no preço do açúcar cristal industrial influencia os preços do açúcar cristal exportado e do álcool anidro; b) variação no preço do álcool anidro influencia os preços do açúcar cristal industrial e do açúcar cristal exportado; c) variação no preço do açúcar cristal exportado influencia o preço do açúcar cristal industrial; e d) variação no preço do açúcar cristal empacotado ao varejo influencia o preço do açúcar cristal empacotado ao produtor. 
Os modelos VEC para essas alternativas foram especificados com as variáveis na primeira diferença e dois vetores de co-integração, conforme definido nos testes de ADF e de Johansen, respectivamente. Observou-se uma certa estabilidade nos resultados, uma vez que não houve alteração significativa quanto às parcelas de explicação de cada variável nas variâncias dos erros de previsão das demais. O mesmo ocorreu com a função de impulso-resposta.

Nas matrizes de relações contemporâneas, observam-se relações significativas entre os preços do açúcar cristal industrial no mercado interno e o recebido pelas exportações, bem como entre os preços do açúcar cristal empacotado ao produtor e ao varejo. O resultado mostra que um aumento de $1 \%$ no preço do açúcar cristal industrial eleva em $0,21 \%$ o preço recebido pela exportação. Alteração de $1 \%$ no preço recebido pelo açúcar cristal exportado motiva variação no mesmo sentido de $0,26 \%$ no preço do açúcar cristal industrial. Por fim, se o preço do açúcar cristal empacotado ao varejo alterar em $1 \%$, o preço ao produtor altera $0,57 \%$ no mesmo sentido. O preço do álcool anidro, por sua vez, não explica contemporaneamente os preços dos açúcares cristal industrial e exportado.

Nas decomposições das variâncias do erro de previsão do preço do açúcar cristal industrial, este se mostrou relativamente independente das demais variáveis. A relação mais expressiva foi observada com o preço do açúcar cristal empacotado ao produtor.

Para o preço do álcool anidro, destaca-se, nas decomposições da variância do erro de previsão, o seu relacionamento com o preço do açúcar cristal industrial e com o preço do açúcar cristal empacotado ao produtor. O preço do açúcar cristal industrial influencia mais o preço do álcool anidro do que o contrário.

No caso do preço recebido pela exportação do açúcar cristal, verifica-se dependência em relação às variáveis de mercado interno. Dessas variáveis, as que mais se destacam na explicação da variância do erro de previsão são os preços do açúcar cristal industrial e do açúcar cristal empacotado ao produtor.

O preço do açúcar cristal empacotado ao produtor, por sua vez, apresentou dependência do preço do açúcar cristal industrial e, em menor intensidade, do preço do 
açúcar cristal empacotado ao varejo. Por fim, para o preço do mercado varejista do açúcar cristal empacotado, os resultados mostram, conforme já se esperava, a forte dependência do preço do mercado produtor e independência dos preços das demais variáveis do modelo.

Quanto aos impactos de choques de uma variável sobre as demais, os resultados mostram que choque no preço do açúcar cristal industrial causa impacto positivo sobre os preços do álcool anidro e do açúcar cristal empacotado ao produtor com um período de defasagem. Sobre o preço do açúcar cristal exportado o impacto ocorre apenas a partir do terceiro mês, corroborando os resultados encontrados na decomposição da variância do erro de previsão.

Choque no preço do álcool anidro impacta positivamente os preços do açúcar cristal industrial e do cristal exportado apenas no quarto período após o choque, sendo esses impactos de pequena magnitude. Choque no preço do açúcar cristal exportado praticamente não causa impacto nos preços de mercado interno.

O choque no preço do açúcar cristal empacotado ao produtor tem influência sobre os preços dos açúcares cristal industrial, cristal exportado e cristal empacotado ao varejo. Os impactos sobre os preços dos açúcares cristal industrial e cristal empacotado ao varejo ocorrem com um período de defasagem, sendo expressivos no início e praticamente desaparecendo cinco meses após o choque. O impacto sobre o preço do açúcar cristal exportado ocorre somente no quarto período.

Choque no preço do mercado varejista do açúcar cristal empacotado, ao contrário do que se esperava, causa impacto negativo sobre os preços dos açúcares cristal industrial e cristal empacotado ao produtor. Somente no terceiro período que o impacto sobre o preço do açúcar cristal industrial é positivo, mas a elasticidade é pequena.

Em termos gerais, os resultados apontam para inter-relações entre os preços ao produtor do álcool anidro e dos açúcares cristal exportado, cristal industrial e cristal empacotado, uma vez que choque em quaisquer das variáveis tem impacto na mesma direção sobre as demais, principalmente após um pequeno período de tempo de ajustamento. Apesar das relações contemporâneas apontarem para inter-relação entre os 
preços do açúcar cristal exportado e do açúcar cristal industrial, o preço externo não se mostrou importante para explicar os preços de mercado interno em períodos posteriores, o que leva a concluir que o seu efeito é imediato.

A decomposição da variância do erro de previsão e os impactos dos choques não mostram relações tão expressivas, quanto se esperava, no curto prazo, entre os preços ao produtor de açúcar e álcool. Esse fato pode estar sendo causado pelo pequeno número de observações da amostra, para o período pós-desregulamentação, que pode ter impedido a identificação precisa do padrão sistemático de associação e de dependência entre as variáveis, e pela recente desregulamentação do setor.

Neste período de transição, a arbitragem em termos de produção e comercialização nesses segmentos pode não ter sido feita de maneira eficiente para assegurar um relacionamento mais estreito entre essas variáveis. Podem ainda ser citados como fatores que explicam a arbitragem não tão eficiente: as diferenças de estrutura entre os segmentos de açúcar e álcool; a busca de abastecimento interno de álcool; a maior concentração do mercado comprador de álcool em relação ao de açúcar, tendo, dessa forma, maior força de negociação; e a atuação do governo no setor de álcool, apesar de pequena, em parte do período sob análise, na busca de maior estabilidade de preços através de estoques reguladores. De outro lado, os produtores do setor sucroalcooleiro podem estar praticando uma política de discriminação de preços e considerando os mercados dos diferentes produtos de forma individual, apesar de dependerem da mesma matéria-prima. Com isto, ocorreria grande rigidez no mix de produção definido para a safra e os produtores de açúcar e álcool não estariam arbitrando, no curto prazo, de forma a responder a sinais de preços dos mercados individuais. No longo prazo, no entanto, os produtores estariam respondendo a sinais de preços.

Finaliza-se o presente trabalho recomendando que novas pesquisas sejam empreendidas no futuro, com séries de preços que representem melhor a atual sistemática de comercialização vigente. Assim, poder-se-á obter interpretações definitivas sobre o processo de transmissão de preços entre produtos do setor sucroalcooleiro do Estado de São Paulo. 
ANEXOS 


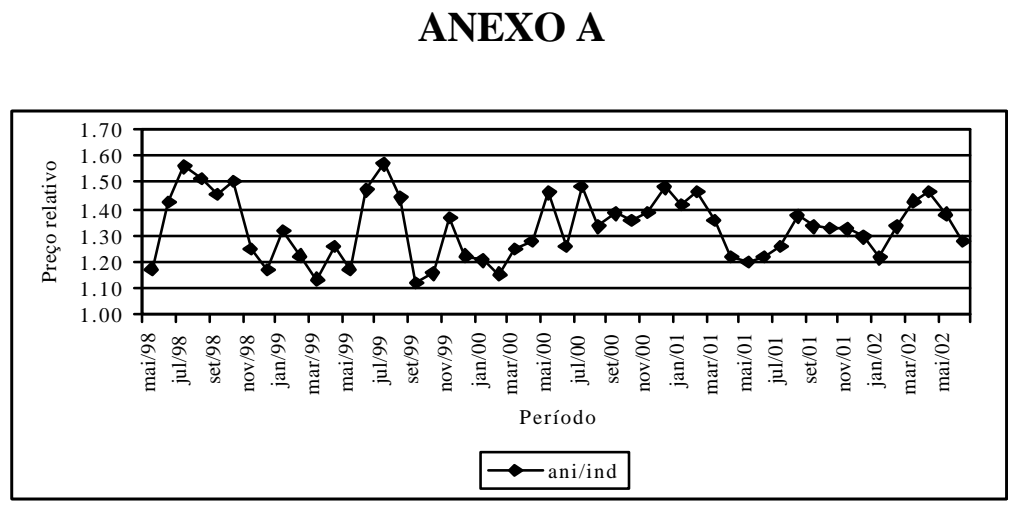

Figura 25 - Evolução do preço relativo entre os preços do álcool anidro (ani) e do açúcar cristal industrial (ind), maio/1998 a jun./2002.

Fonte: CEPEA (2002)

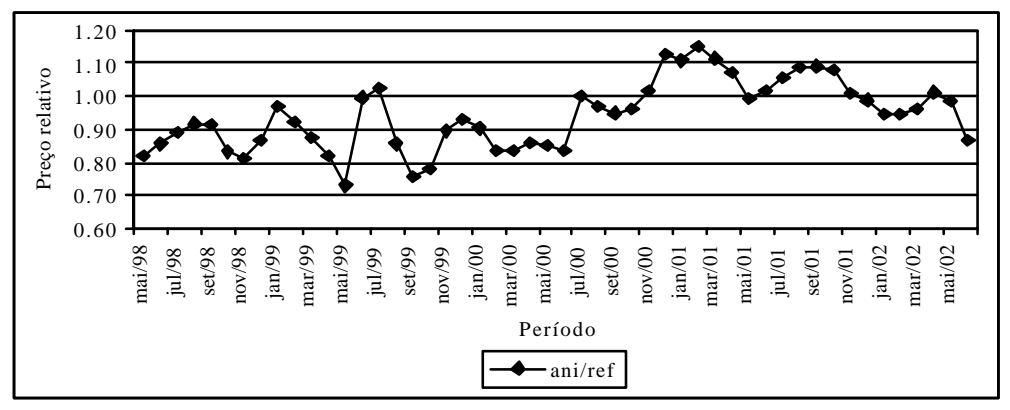

Figura 26 - Evolução do preço relativo entre os preços do álcool anidro (ani) e do açúcar refinado ao produtor (ref), maio/1998 a jun./2002.

Fonte: CEPEA (2002)

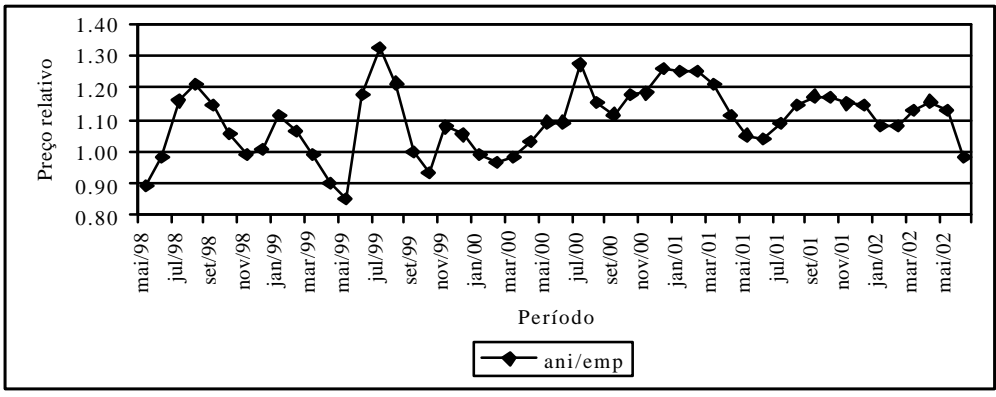

Figura 27 - Evolução do preço relativo entre os preços do álcool anidro (ani) e do açúcar cristal empacotado ao produtor (emp), maio/1998 a jun./2002.

Fonte: CEPEA (2002)

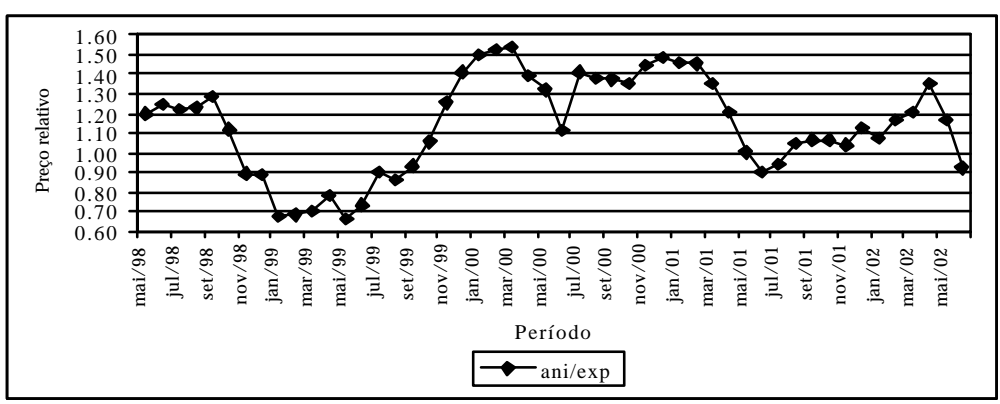

Figura 28 - Evolução do preço relativo entre os preços do álcool anidro (ani) e do açúcar cristal exportado (exp), maio/1998 a jun./2002.

Fonte: CEPEA (2002) 


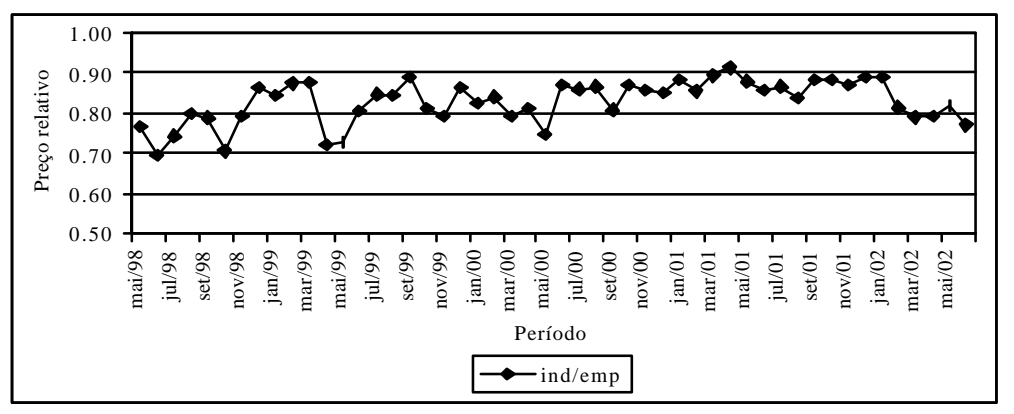

Figura 29 - Evolução do preço relativo entre os preços do açúcar cristal industrial (ind) e do açúcar cristal empacotado ao produtor (emp), maio/1998 a jun./2002.

Fonte: CEPEA (2002)

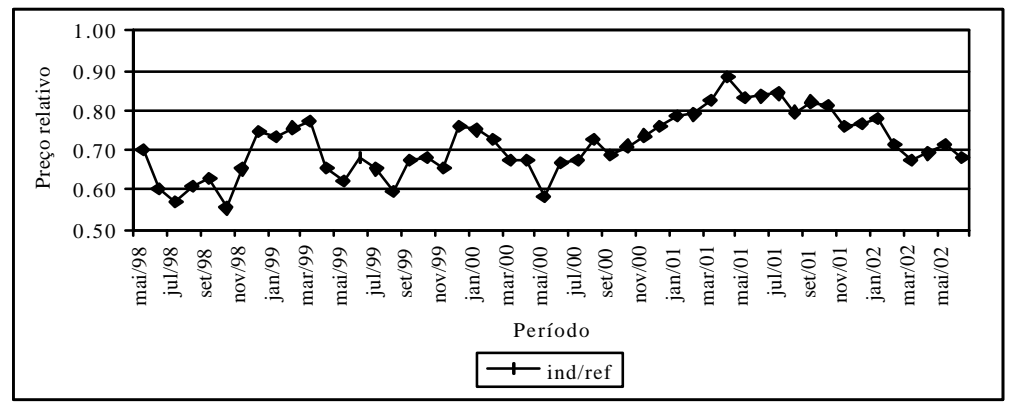

Figura 30 - Evolução do preço relativo entre os preços do açúcar cristal industrial (ind) e do açúcar refinado ao produtor (ref), maio/1998 a jun./2002.

Fonte: CEPEA (2002)

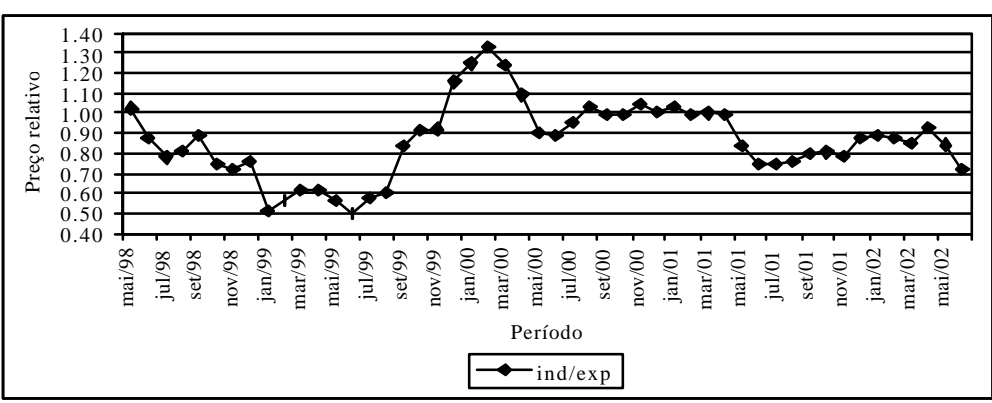

Figura 31 - Evolução do preço relativo entre os preços do açúcar cristal industrial (ind) e do açúcar cristal exportado (exp), maio/1998 a jun./2002.

Fonte: CEPEA (2002)

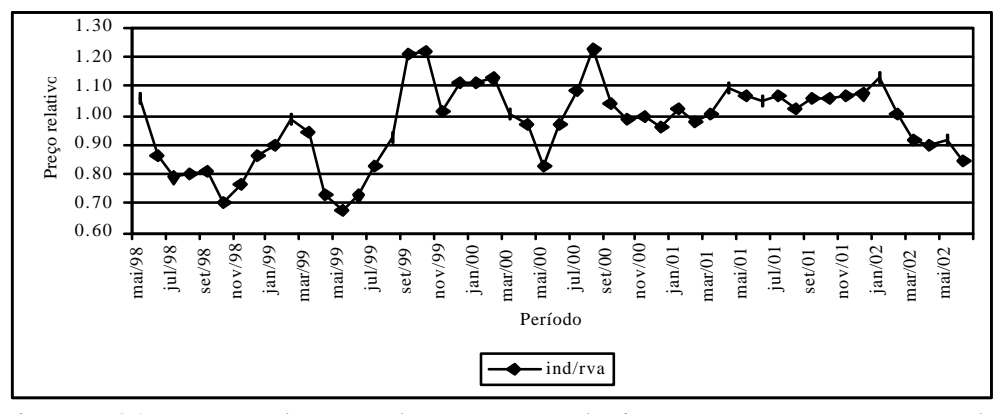

Figura 32 - Evolução do preço relativo entre os preços do açúcar cristal industrial (ind) e do açúcar refinado ao varejo (rva), maio/1998 a jun./2002.

Fonte: CEPEA (2002) 


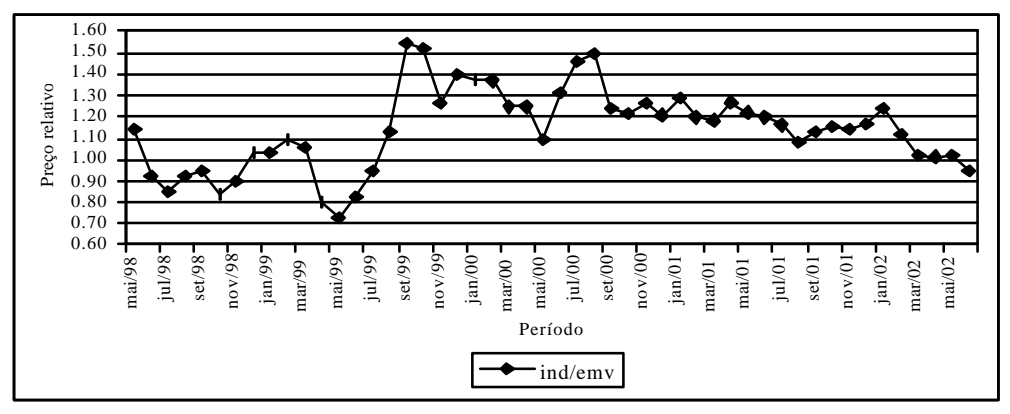

Figura 33 - Evolução do preço relativo entre os preços do açúcar cristal industrial (ind) e do açúcar cristal empacotado ao varejo (emv), maio/1998 a jun./2002.

Fonte: CEPEA (2002)

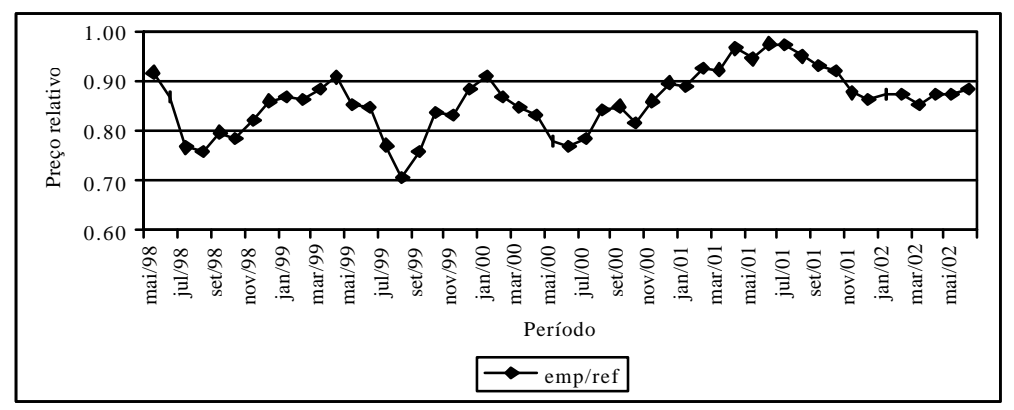

Figura 34 - Evolução do preço relativo entre os preços do açúcar cristal empacotado ao produtor (emp) e do açúcar refinado ao produtor (ref), maio/1998 a jun./2002.

Fonte: CEPEA (2002)

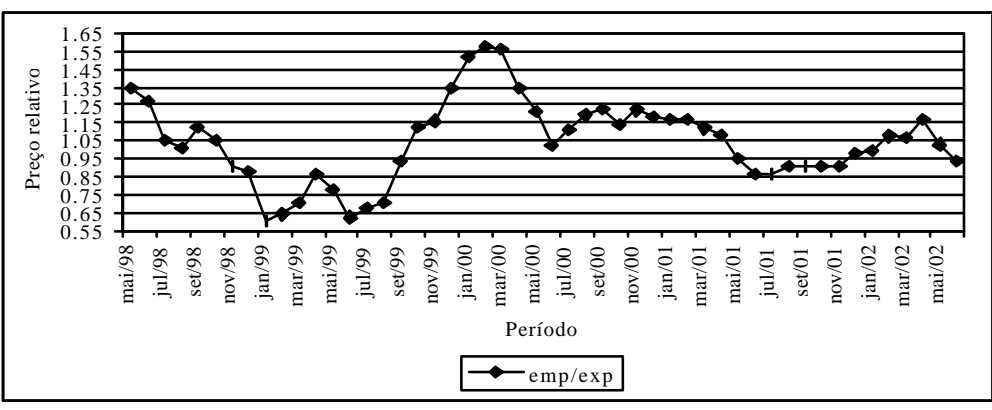

Figura 35 - Evolução do preço relativo entre os preços do açúcar cristal empacotado ao produtor (emp) e do açúcar cristal exportado (exp), maio/1998 a jun./2002.

Fonte: CEPEA (2002)

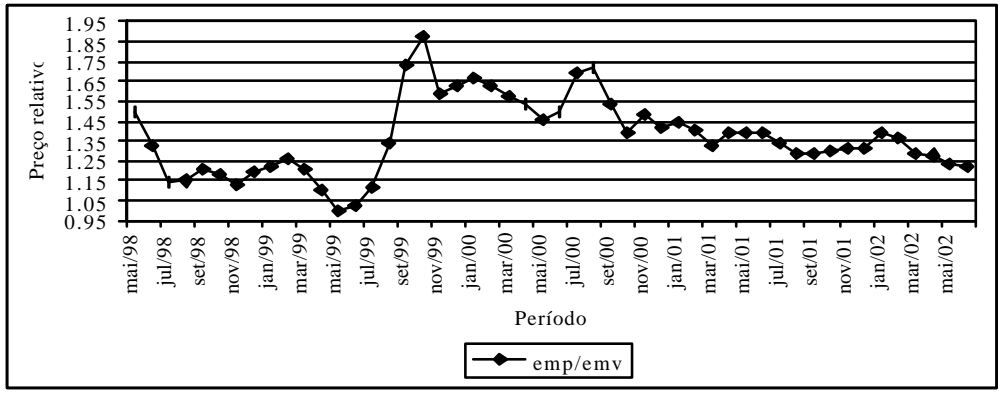

Figura 36 - Evolução do preço relativo entre os preços do açúcar cristal empacotado ao produtor (emp) e do açúcar cristal empacotado ao varejo (emv), maio/1998 a jun./2002.

Fonte: CEPEA (2002) 


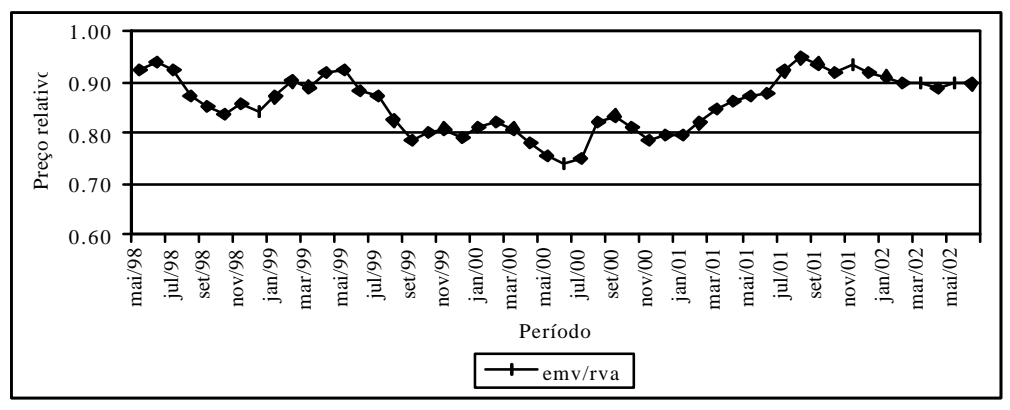

Figura 37 - Evolução do preço relativo entre os preços do açúcar cristal empacotado ao varejo (emv) e do açúcar refinado ao varejo (rva), maio/1998 a jun./2002.

Fonte: CEPEA (2002)

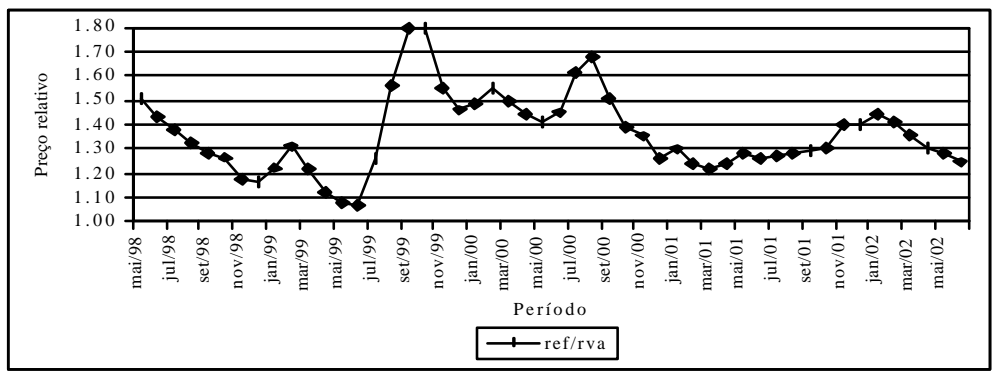

Figura 38 - Evolução do preço relativo entre os preços do açúcar refinado ao produtor (ref) e o açúcar refinado ao varejo (rva), maio/1998 a jun./2002.

Fonte: CEPEA (2002) 


\section{ANEXO B}

Tabela 26. Decomposição histórica da variância do erro de previsão para o preço do açúcar cristal industrial (Modelo 2).

\begin{tabular}{ccccccc}
\hline \multirow{2}{*}{ Mês } & & \multicolumn{2}{c}{ Decomposição da variância devida a choques (\%) } \\
\cline { 3 - 7 } & padrão & $\begin{array}{c}\text { Cristal } \\
\text { indúst. }\end{array}$ & $\begin{array}{c}\text { Álcool } \\
\text { anidro }\end{array}$ & $\begin{array}{c}\text { Cristal } \\
\text { export. }\end{array}$ & $\begin{array}{c}\text { Cristal } \\
\text { empac. }\end{array}$ & $\begin{array}{c}\text { Empac. } \\
\text { varejo }\end{array}$ \\
\hline 1 & 0.069 & 99.982 & 0.018 & 0.000 & 0.000 & 0.000 \\
2 & 0.075 & 93.269 & 0.031 & 0.031 & 4.149 & 2.521 \\
3 & 0.076 & 92.329 & 0.079 & 0.456 & 4.138 & 2.998 \\
4 & 0.077 & 90.866 & 0.647 & 0.681 & 4.541 & 3.266 \\
5 & 0.078 & 90.346 & 0.640 & 0.769 & 5.021 & 3.224 \\
6 & 0.078 & 90.274 & 0.663 & 0.826 & 5.008 & 3.230 \\
7 & 0.078 & 90.235 & 0.665 & 0.844 & 5.036 & 3.220 \\
\hline
\end{tabular}

Fonte: Dados da pesquisa

Tabela 27. Decomposição histórica da variância do erro de previsão para o preço do álcool anidro (Modelo 2).

\begin{tabular}{ccrcccc}
\multicolumn{8}{c}{ 2). } & \multicolumn{7}{c}{ Decomposição da variância devida a choques (\%) } \\
\cline { 3 - 7 } Mês & $\begin{array}{c}\text { Desvio- } \\
\text { padrão }\end{array}$ & $\begin{array}{c}\text { Cristal } \\
\text { indúst. }\end{array}$ & $\begin{array}{c}\text { Álcool } \\
\text { anidro }\end{array}$ & $\begin{array}{c}\text { Cristal } \\
\text { export. }\end{array}$ & $\begin{array}{c}\text { Cristal } \\
\text { empac. }\end{array}$ & $\begin{array}{c}\text { Empac. } \\
\text { Varejo }\end{array}$ \\
\hline 1 & 0.032 & 0.000 & 100.000 & 0.000 & 0.000 & 0.000 \\
2 & 0.035 & 0.045 & 87.887 & 0.817 & 9.334 & 1.917 \\
3 & 0.045 & 17.200 & 61.948 & 4.542 & 14.012 & 2.297 \\
4 & 0.049 & 24.986 & 55.103 & 4.169 & 12.431 & 3.311 \\
5 & 0.050 & 24.148 & 54.765 & 4.144 & 12.413 & 4.531 \\
6 & 0.052 & 27.429 & 51.876 & 4.189 & 12.017 & 4.489 \\
7 & 0.052 & 27.281 & 51.438 & 4.668 & 12.142 & 4.470 \\
\hline
\end{tabular}

Tabela 28. Decomposição histórica da variância do erro de previsão para o preço do açúcar cristal exportado (Modelo 2).

\begin{tabular}{rrrrrrr}
\hline & & \multicolumn{2}{c}{ Decomposição da variância devida a choques (\%) } \\
\cline { 3 - 7 } Mês & $\begin{array}{c}\text { Desvio- } \\
\text { padrão }\end{array}$ & $\begin{array}{c}\text { Cristal } \\
\text { indúst. }\end{array}$ & $\begin{array}{c}\text { Alcool } \\
\text { anidro }\end{array}$ & $\begin{array}{r}\text { Cristal } \\
\text { export. }\end{array}$ & $\begin{array}{r}\text { Cristal } \\
\text { empac. }\end{array}$ & $\begin{array}{c}\text { Empac. } \\
\text { Varejo }\end{array}$ \\
\hline 1 & 0.074 & 0.000 & 0.631 & 99.369 & 0.000 & 0.000 \\
2 & 0.079 & 2.665 & 6.691 & 85.618 & 0.704 & 4.321 \\
3 & 0.097 & 20.014 & 5.897 & 57.507 & 13.221 & 3.361 \\
4 & 0.100 & 20.708 & 5.693 & 56.839 & 13.565 & 3.195 \\
5 & 0.101 & 20.984 & 5.593 & 56.253 & 13.876 & 3.295 \\
6 & 0.101 & 20.818 & 6.117 & 55.834 & 13.817 & 3.415 \\
7 & 0.101 & 20.814 & 6.113 & 55.840 & 13.819 & 3.414 \\
\hline
\end{tabular}

Fonte: Dados da pesquisa

Tabela 29. Decomposição histórica da variância do erro de previsão para o preço do açúcar cristal empacotado ao produtor (Modelo 2).

\begin{tabular}{ccrcccc}
\hline & & \multicolumn{5}{c}{ Decomposição da variância devida a choques (\%) } \\
\cline { 3 - 7 } Mês & $\begin{array}{c}\text { Desvio- } \\
\text { padrão }\end{array}$ & $\begin{array}{r}\text { Cristal } \\
\text { indúst. }\end{array}$ & $\begin{array}{c}\text { Alcool } \\
\text { anidro }\end{array}$ & $\begin{array}{c}\text { Cristal } \\
\text { export. }\end{array}$ & $\begin{array}{r}\text { Cristal } \\
\text { empac. }\end{array}$ & $\begin{array}{c}\text { Empac. } \\
\text { Varejo }\end{array}$ \\
\hline 1 & 0.037 & 0.000 & 0.000 & 0.000 & 100.000 & 0.000 \\
2 & 0.046 & 19.894 & 0.893 & 2.915 & 69.887 & 6.411 \\
3 & 0.049 & 25.368 & 0.802 & 3.950 & 64.284 & 5.597 \\
4 & 0.050 & 24.903 & 1.684 & 4.219 & 63.474 & 5.720 \\
5 & 0.050 & 24.805 & 1.835 & 4.260 & 63.381 & 5.719 \\
6 & 0.050 & 25.077 & 1.871 & 4.286 & 63.081 & 5.685 \\
7 & 0.050 & 25.062 & 1.870 & 4.340 & 63.045 & 5.682 \\
\hline
\end{tabular}


Tabela 30. Decomposição histórica da variância do erro de previsão para o preço do açúcar cristal empacotado ao varejo (Modelo 2).

Decomposição da variância devida a choques (\%)

\begin{tabular}{cccccrr}
\hline & & \multicolumn{2}{c}{ Decomposição da variância devida a choques (\%) } \\
\cline { 3 - 7 } Mês & $\begin{array}{c}\text { Desvio } \\
\text { padrão }\end{array}$ & $\begin{array}{c}\text { Cristal } \\
\text { indúst. }\end{array}$ & $\begin{array}{c}\text { Álcool } \\
\text { anidro }\end{array}$ & $\begin{array}{c}\text { Cristal } \\
\text { export. }\end{array}$ & $\begin{array}{r}\text { Cristal } \\
\text { empac. }\end{array}$ & $\begin{array}{r}\text { Empac. } \\
\text { Varejo }\end{array}$ \\
\hline 1 & 0.022 & 0.000 & 0.000 & 0.000 & 0.000 & 100.000 \\
2 & 0.026 & 0.704 & 1.450 & 0.183 & 24.195 & 73.467 \\
3 & 0.028 & 3.723 & 3.308 & 0.203 & 28.996 & 63.770 \\
4 & 0.029 & 3.876 & 3.189 & 2.972 & 28.288 & 61.676 \\
5 & 0.029 & 5.156 & 4.362 & 3.135 & 27.364 & 59.983 \\
6 & 0.030 & 6.744 & 4.402 & 3.132 & 27.185 & 58.537 \\
7 & 0.030 & 6.934 & 4.441 & 3.339 & 27.030 & 58.256 \\
\hline
\end{tabular}

Fonte: Dados da pesquisa

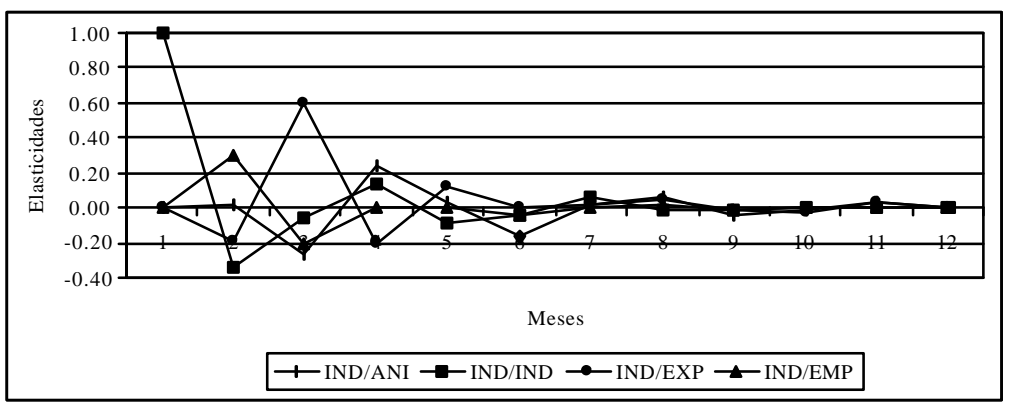

Figura 39 - Função de resposta dos preços do açúcar cristal industrial (ind), do álcool anidro (ani), do açúcar cristal exportado (exp) e do açúcar cristal empacotado ao produtor (emp), a impulso no preço do açúcar cristal industrial (Modelo 2).

Fonte: Dados da pesquisa

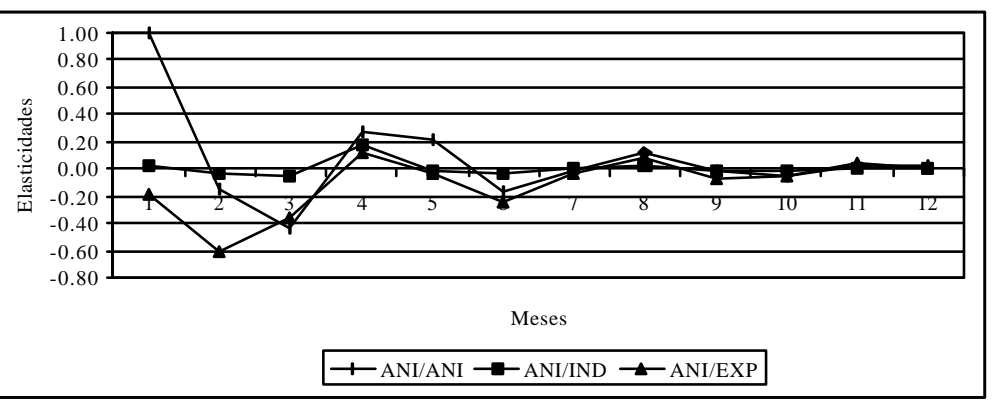

Figura 40 - Função de resposta dos preços do açúcar cristal industrial (ind), do álcool anidro (ani) e do açúcar cristal exportado (exp), a impulso no preço do álcool anidro (Modelo 2).

Fonte: Dados da pesquisa

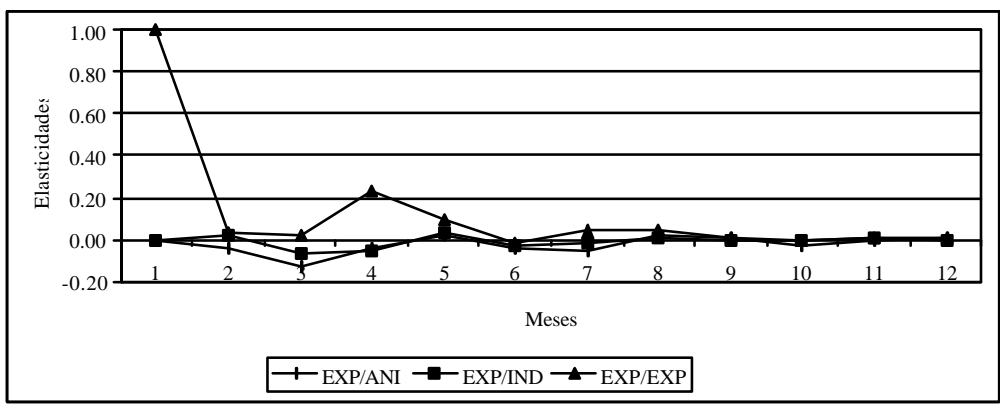

Figura 41 - Função de resposta dos preços do açúcar cristal industrial (ind), do álcool anidro (ani) e do açúcar cristal exportado (exp), a impulso no preço do açúcar cristal exportado (Modelo 2).

Fonte: Dados da pesquisa 


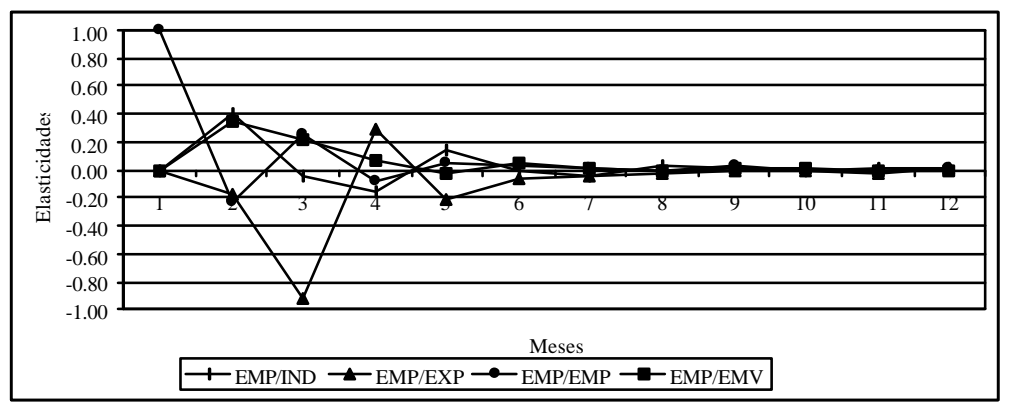

Figura 42 - Função de resposta dos preços dos açúcares cristal industrial (ind), do cristal exportado (exp) e do cristal empacotado ao produtor (emp) e ao varejo (emv), a impulso no preço do açúcar cristal empacotado ao produtor (Modelo 2).

Fonte: Dados da pesquisa

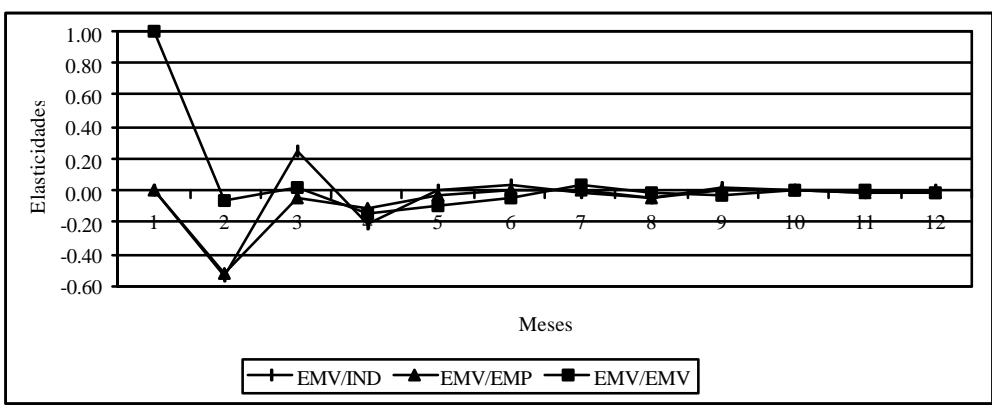

Figura 43 - Função de resposta dos preços do açúcar cristal industrial (ind) e do açúcar cristal empacotado ao produtor (emp) e ao varejo (emv), a impulso no preço do açúcar cristal empacotado ao varejo (Modelo 2).

Fonte: Dados da pesquisa 


\section{REFERÊNCIAS BIBLIOGRÁFICAS}

AGUIAR, D.R.D. de. Formação de preços na indústria brasileira de soja - 1982/1989. Piracicaba, 1990. 140p. Dissertação (M.S) - Escola Superior de Agricultura "Luiz de Queiroz", Universidade de São Paulo.

AGUIAR, D.R.D. de. Transmissão de preços mensais entre os mercados externo e interno: uma aplicação do modelo de Mundlak-Larson. Revista de Economia e Sociologia Rural, v.33, n.4, p.43-50, out./dez. 1995.

AGUIAR, D.R.D.; BARROS, G.S.A. de C. Análise dinâmica de margens de comercialização: uma aplicação aos mercados de arroz e de feijão no Estado de São Paulo. Revista Brasileira de Economia, v.49, n.4, p.583-610, out./dez. 1995.

ALMEIDA, C.O. de; MESQUITA, T.C. Causalidade entre preços externos e quantidades exportadas de café do Brasil no mercado internacional - 1965/89. Pesquisa e Planejamento Econômico, v.25, n.3, p.527-540, dez. 1995.

ALVES, J.M. Transmissão de preços e margens de comercialização de abacaxi, banana e laranja em Minas Gerais. Viçosa, 1996. 74p. Dissertação (M.S) - Universidade Federal de Viçosa.

ASSOCIAÇÃO DE PRODUTORES DE ÁlCOOL E AÇÚCAR DO ESTADO DO PARANÁ - ALCOPAR. Mercado de açúcar. http://www.alcopar.org.br/estatdiv/ macucar.htm (10 Fev. 2002).

AZEVEDO, F. de. Canaviais e engenhos na vida política do Brasil. 2.ed. São Paulo: Melhoramentos, 1958. 186p.

BACCHI, M.R.P. Causalidade entre preços no mercado de carnes do Estado de São Paulo. Revista de Economia e Sociologia Rural, v.34, n.2, p.51-60, nov./dez. 1995. 
BACCHI, M.R.P. Previsão de preços de bovino, suíno e frango com modelos de séries temporais. Piracicaba, 1994. 172p. Tese (Doutorado) - Escola Superior de Agricultura "Luiz de Queiroz", Universidade de São Paulo.

BACCHI, M.R.P. Transmissão de preços entre os segmentos produtivos da pecuária de corte brasileira (compact disc). In: CONGRESSO BRASILEIRO DE ECONOMIA E SOCIOLOGIA, 37., Foz do Iguaçu, 1999. Anais. Brasília: SOBER, 1999.

BACCHI, M.R.P.; ALVES, L.R.A.; SILVEIRA. A.M. Exportações brasileiras de açúcar: um modelo de auto-regressão vetorial (compact disc). In: CONGRESSO BRASILEIRO DE ECONOMIA E SOCIOLOGIA RURAL, 40., Passo Fundo, 2002. Anais. Brasília: SOBER, 2002.

BACCHI, M.R.P.; HOFFMANN, R. Previsão de preços de bovino e frango com modelos de séries temporais. Revista de Economia e Sociologia Rural, v.33, n.4, p.9-28, out./dez. 1995.

BACCHI, M.R.P.; MARJOTTA-MAISTRO, M.C. Comportamento do preço do açúcar no Estado de São Paulo. Preços Agrícolas, v.14, n.158, p.11-13, dez. 1999.

BAER, W. A economia brasileira. São Paulo: Nobel, 1996. 416p.

BARROS, G.S.A. de C. Economia da comercialização agrícola. Piracicaba: FEALQ, 1987. 240p.

BARROS, G.S.A. de C. Transmissão de preços pela Central de Abastecimento de São Paulo, Brasil. Revista Brasileira de Economia, v.44, n.1, p.5-20, jan./mar. 1990.

BARROS, W.J. de. Análise econométrica dos mercados interno e de exportação de açúcar. Viçosa, 1975. 46p. Dissertação (M.S) - Universidade Federal de Viçosa.

BELIK, W.; RAMOS, P.; VIAN, C.E.F. Mudanças institucionais e sus impactos nas estratégias dos capitais do complexo agroindustrial canavieiro no Centro-Sul do Brasil. In: CONGRESSO BRASILEIRO DE ECONOMIA E SOCIOLOGIA RURAL, 36., Poços de Caldas, 1998. Anais. Brasília: SOBER, 1998. P.519-532.

BERNANKE, B.S. Alternative explanations of the money-income correlation. Carnegie-Rochester Conference Series on Public Policy, v.25, p.49-100, 1986. 
BITTENCOURT, M.V.L. Formação de preços e caracterização do mercado de frango em São Paulo. Piracicaba, 1995. 161p. Dissertação (M.S) - Escola Superior de Agricultura "Luiz de Queiroz", Universidade de São Paulo.

BLISKA, F.M. de M. Transmissão de preços de carne bovina entre níveis de mercado: uma aplicação do modelo de auto-regressão vetorial. Piracicaba, 1989. 209p. Dissertação (M.S) - Escola Superior de Agricultura "Luiz de Queiroz", Universidade de São Paulo.

BLISKA, F.M. de M.; BARROS, G.S.A. de C. Formação de preço de carne bovina: uma aplicação do modelo de auto-regressão vetorial. Agricultura em São Paulo, v.37, n.3. p.41-59, 1990.

BOX, G.E.P.; JENKINS, G.M. Time series analysis: forescasting and control. San Francisco: Holden-Day, 1976. 182p.

BRAY, S.C. A formação do capital na agroindústria açucareira de São Paulo: revisão de paradigmas tradicionais. Rio Claro, 1989. 170p. Tese (Livre-Docência) - Instituto de Geociências e Ciências Exatas, Universidade Estadual Paulista.

BRAY, S.C.; FERREIRA, E.R.; RUAS, D.G.G. As políticas da agroindústria canavieira e o Proálcool no Brasil. Marília: UNESP/Marília Publicações, 2000. $104 \mathrm{p}$.

BURNQUIST, H.L. A questão da causalidade entre preços a diferentes níveis de mercados agrícolas. Piracicaba, 1986. 83p. Dissertação (M.S) - Escola Superior de Agricultura "Luiz de Queiroz”, Universidade de São Paulo.

BURNQUIST, H.L.; BACCHI, M.R.P.; MARJOTTA-MAISTRO, M.C. Análise da comercialização dos produtos do setor sucroalcooleiro brasileiro: evolução, contexto institucional e desempenho. In: MORAES, M.A.F.D. de; SHIKIDA, P.F.A. (Org.). Agroindústria canavieira no Brasil: evolução, desenvolvimento e desafios. São Paulo: Atlas, 2002. cap.8, p.182-198. 
CÂMARA, S.; MAIA, S.F.; LIMA, R.C. A formação de preços da soja no Brasil: uma visão sistemática considerando os efeitos de "feedback" em modelo tipo VAR (compact disc). In: WORLD CONGRESS OF RURAL SOCIOLOGY, 10; BRAZILIAN CONGRESS OF RURAL ECONOMY AND SOCIOLOGY, 38., Rio de Janeiro, 2000. Anais. Brasília: SOBER, 2000.

CARUSO, R.C. Análise da oferta e demanda de açúcar no Estado de São Paulo. Piracicaba, 2002. 79p. Dissertação (M.S) - Escola Superior de Agricultura "Luiz de Queiroz", Universidade de São Paulo.

CARUSO, R.C.; BURNQUIST, H.L. Análise estrutural do mercado de açúcar no Estado de São Paulo (compact disc). In: CONGRESSO BRASILEIRO DE ECONOMIA E SOCIOLOGIA RURAL, 39., Recife, 2001. Anais. Brasília: SOBER, 2001.

CARVALHO, C.P. de. Bem, obrigado. Agroanalysis, v.20, n.8, p.42-43, ago. 2000.

CARVALHO, F.C. de; BRANDT, S.A.; NOGUEIRA JÚNIOR, S.; DIAS, R.S. Preços de algodão nos mercados interno e externo: uma análise de causalidade. Revista de Economia Rural, v.21, n.2, p.241-249, abr.jun. 1983.

CARVALHO, F.C. de; MARQUES, S.A.; MAIA, M.L.; YOSHII, R.J. Estudo da integração vertical na agroindústria sucroalcooleira no Estado de São Paulo, 197092. Agricultura em São Paulo, v.40, n.1, p.157-182, 1993.

CARVALHO, L.C.C. Pesos diferentes. Agroanalysis, v.20, n.3, p.41-45, mar. 2000.

CENTRO DE ESTUDO AVANÇADOS EM ECONOMIA APLICADA - CEPEA. Indicadores de preços. http://www.cepea.esalq.usp.br (10 jul. 2002)

COSTA, C.C. da. Formação de preços de açúcar e álcool combustível anidro e hidratado no Estado de São Paulo. Piracicaba, 2000. 104p. Dissertação (M.S) Escola Superior de Agricultura “Luiz de Queiroz”, Universidade de São Paulo.

DICKEY, D.A.; FULLER, W.A. Distribution of the estimators for autorregressive time series with unit root. Journal of the American Statistical Association, v.74, n.366, p.427-431, June 1979.

DICKEY, D.A.; FULLER, W.A. Likelihood ratio statistics for autoregressive time series with a unit root. Econometrica, v.49, n.4, p.1057-1072, July 1981. 
ENDERS, W. Applied econometric time series. New York: John Wiley \& Sons, 1995. $433 p$.

ENGLE, R.F.; GRANGER, C.W.J. Co-integração and error corretion: representation, estimation, and testing. Econometrica, v.55, n.2, p.251-276, Mar. 1987.

F.O.LICHT'S. International sugar and sweetener report: world sugar balances 1991/92-2000/01. Ratzeburg, 2001. 32p.

FELIPPI, E.E.; WAQUIL, P.D. Transmissão de preços entre os níveis de mercado de atacado e varejo: metodologia e estudo de caso na região metropolitana de Porto Alegre (compact disc). In: CONGRESSO BRASILEIRO DE ECONOMIA E SOCIOLOGIA, 37., Foz do Iguaçu, 1999. Anais. Brasília: SOBER, 1999.

FERREIRA, C.M. Comercialização de feijão no Brasil 1990-99. Piracicaba, 2001. 145p. Dissertação (M.S) - Escola Superior de Agricultura "Luiz de Queiroz", Universidade de São Paulo.

FREITAS, S.M. de; MARGARIDO, M.A.; BARBOSA, M.Z.; FRANCA, T.J.F. Análise da dinâmica de transmissão de preços no mercado internacional de farelo de soja, 1990-99. Agricultura em São Paulo, v.48, n.1, p.1-20, 2001.

FULLER, W.A. Introduction to statistical time series. New York: John Wiley, 1976. $424 \mathrm{p}$.

FURTADO, C. Formação econômica do Brasil. 12.ed. Rio de Janeiro: Nacional, 1974. 248p.

GARDNER, B.L. The farm-retail price spread in a competitive food industry. American Journal of Agricultural Economics, v.53, n.3, p.399-409, 1975.

GRANGER, C.W.J. Investigating causal relations by econometric models and cross spectral methods. Econometrica, v.37, n.3, p.424-438, 1969.

GUIMARÃES, V.D.A. Comercialização e transmissão de preços de carne de frango no Estado de São Paulo. Piracicaba, 1990. 119p. Dissertação (M.S) - Escola Superior de Agricultura "Luiz de Queiroz", Universidade de São Paulo.

GUJARATI, D.N. Econometria básica. São Paulo: MAKRON Books, 2000. 846p.

HAMILTON, J.D. Time series analysis. New Jersey: Princeton University Press, 1994. 799 p. 
HEIEN, D.M. Markup pricing in a dynamic model of the food industry. American Journal of Agricultural Economics, v.62, n.1, p.10-18, 1980.

INSTITUTO BRASILEIRO DE GEOGRAFIA E ESTATÍSTICA - IBGE. Índices de preços. Índice nacional de preços ao consumidor. http://www.sidra.ibge.gov.br/ bda/tabela/listabl.asp?c $=654 \& \mathrm{z}=\mathrm{t} \& \mathrm{o}=1(10 \mathrm{Jul} .2002)$

JOHANSEN, S. Statistical analysis of cointegration vectors. Journal of Economics Dynamics and Control, v.12, n.2/3, p.231-254, 1988.

JOHANSEN, S.; JUSELIUS, K. Maximum likelihood estimation and inference on cointegration: with applications to the demand for money. Oxford Bulletin of Economics and Statistics, v.52, n.2, p.169-210, 1990.

JORNALCANA. Dados \& estatísticas. http://www.jornalcana.com.br (21 jun. 2002)

LIMA, R.C.; SAMPAIO, Y. Estimação de função de transferência para o preço do açúcar: uma aplicação do modelo ARMAX. In: SAMPAIO, Y. (Org.). Açúcar amargo: crise e perspectiva da indústria sucro-alcooleira em Pernambuco. Recife: UFPE, 1999b. p.115-122.

LIMA, R.C.; SAMPAIO, Y. Uma análise de estabilidade, transmissão e previsão do preço do açúcar. In: SAMPAIO, Y. (Org.). Açúcar amargo: crise e perspectiva da indústria sucro-alcooleira em Pernambuco. Recife: UFPE, 1999. p.101-112.

MACHADO, F. de B.P. Açúcar, o doce sabor do prazer. http://www.jornalcana. com.br/Conteudo/Historiadosetor.htm (26 jan. 2002)

MAFIOLETTI, R.L.; BARROS, G.S.A. de C. Formação de preço na cadeia agroindustrial da soja na década de 90 (compact disc). In: CONGRESSO BRASILEIRO DE ECONOMIA E SOCIOLOGIA, 38., Rio de Janeiro, 2000. Anais. Brasília: SOBER, 2000.

MARGARIDO, M.A. Transmissão de preços agrícolas internacionais sobre preços agrícolas domésticos: o caso do Brasil. Piracicaba, 2000. 173p. Tese (Doutorado) Escola Superior de Agricultura “Luiz de Queiroz”, Universidade de São Paulo. 
MARGARIDO, M.A. Transmissão de preços internacionais de suco de laranja para preços ao nível de produtor de laranja no Estado de São Paulo. São Paulo, 1994. 96p. Dissertação (M.S) - Escola de Administração de Empresas de São Paulo, Fundação Getúlio Vargas.

MARGARIDO, M.A. Aplicação de testes de raiz unitária com quebra estrutural em séries econômicas no Brasil na década de 90. Informações Econômicas, v.31, n.4, p.7-22, abr. 2001.

MARJOTTA-MAISTRO, M.C. Ajustes nos mercados de álcool e gasolina no processo de desregulamentação. Piracicaba, 2002. 180p. Tese (Doutorado) - Escola Superior de Agricultura “Luiz de Queiroz”, Universidade de São Paulo.

MARJOTTA-MAISTRO, M.C. Análise do consumo industrial de açúcar no Estado de São Paulo. Piracicaba, 1998. 100p. Dissertação (M.S) - Escola Superior de Agricultura “Luiz de Queiroz”, Universidade de São Paulo.

MARQUES, P.V. Margens de comercialização e elasticidade de transmissão de preços de frango. Revista de Economia Rural, v.24, n.3, p.293-302, jul./set. 1986.

MARTINES FILHO, J.G. Margens de comercialização e causalidade de preços agrícolas. Piracicaba, 1988. 146p. Dissertação (M.S) - Escola Superior de Agricultura "Luiz de Queiroz", Universidade de São Paulo.

MORAES, M.A.F.D. de. A desregulamentação do setor sucroalcooleiro do Brasil. Americana: Caminho Editorial, 2000. 238p.

MORAES, M.A.F.D. de. Desregulamentação da agroindústria canavieira: novas formas de atuação do Estado e desafios do setor privado. In: MORAES, M.A.F.D. de; SHIKIDA, P.F.A. (Org.). Agroindústria canavieira no Brasil: evolução, desenvolvimento e desafios. São Paulo: Atlas, 2002. cap.1, p.21-42.

NEVES, L.C. das. Margens de comercialização e elasticidades de transmissão de preços na indústria de esmagamento de soja. Piracicaba, 1993. 90p. Dissertação (M.S) Escola Superior de Agricultura “Luiz de Queiroz”, Universidade de São Paulo. 
NEVES, M.F.; WAAK, R.S.; MAMONE, A. O sistema agroindustrial da cana-deaçúcar: caracterização das transações entre usinas e empresas de alimentos. In: CONGRESSO BRASILEIRO DE ECONOMIA E SOCIOLOGIA RURAL, 36., Poços de Caldas, 1998. Anais. Brasília: SOBER, 1998. p.573-583.

NOGUEIRA, P.R. de M. Longe do equilíbrio. Agroanalysis, v.20, n.3, p.36-37, mar. 2000.

OSTERWALD-LENUM, M. A note with quantiles of the asymptotic distribution of the maximum likelihood cointegration rank test statistics. Oxford Bulletin of Economics and Statistics, v.53, n.3, p.461-472, 1992.

PHILLIPS, P.C.B. Time series regression with a unit root. Econometrica, v.55, n.2 p.277-301, Mar. 1987.

PHILLPS, P.C.B.; PERRON, P. Testing for a unit root in time series regression. Biometrica, v.75, n.2, p.335-346, 1988.

PINAZZA, L.A.; ALIMANDRO, R. Via crucis. Agroanalysis, v.20, n.3, p.14-20, mar. 2000 .

PRADO JÚNIOR, C. História econômica do Brasil. 26.ed. São Paulo: Brasiliense, 1981. 354p.

QUEDA, O. A intervenção do Estado e a agroindústria açucareira paulista. Piracicaba, 1972. 173p. Tese (Doutorado) - Escola Superior de Agricultura "Luiz de Queiroz", Universidade de São Paulo.

RAMOS, P. Agroindústria canavieira e propriedade fundiária no Brasil. São Paulo: HUCITEC, 1999. 243p.

RAMOS, P. Situação atual, problemas e perspectivas da agroindústria canavieira de São Paulo. Informações Econômicas, v.29, n.10, p.9-24, out. 1999b.

RAMOS, P.; BELIK, W. Intervenção estatal e a agroindústria canavieira no Brasil.

Revista de Economia e Sociologia Rural, v.27, n.2, p.197-214, abr./jun. 1989.

SANTOS, E.V.; FETT, M.S. Causalidade e elasticidade na transmissão de preços de maçã entre produtor, atacado e varejo no Rio Grande do Sul (compact disc). In: CONGRESSO BRASILEIRO DE ECONOMIA E SOCIOLOGIA, 37., Foz do Iguaçu, 1999. Anais. Brasília: SOBER, 1999. 
SCHOUCHANA, F.; WIDONSCK, C.A. Formação do preço do açúcar e do álcool na BM\&F. Resenha BM\&F, n.145, p.67-88, maio/jun. 2001.

SHIKIDA, P.F.A. A evolução diferenciada da agroindústria canavieira no Brasil de 1975 a 1995. Cascavel: EDUNIOESTE, 1998. 191p.

SHIKIDA, P.F.A. Alguns aspectos do mercado externo açucareiro e a inserção brasileira neste mercado. Revista Econômica do Nordeste, v.30, n.3, p.372-385, jul./set. 1999.

SILVA, L.M. da; RAMOS, P. Os mercados do agribusines do açúcar e do álcool: produtos concorrentes, situação atual, tendências e perspectivas. In: CONGRESSO BRASILEIRO DE ECONOMIA E SOCIOLOGIA RURAL, 36., Poços de Caldas, 1998. Anais. Brasília: SOBER, 1998. p.547-557.

SIMONSEN, R.C. História econômica do Brasil 1500-1820. 6.ed. Rio de Janeiro: Nacional, 1969. 475p.

SIMS, C.A. Macroeconomics and reality. Econometrica, v.48, n.1, p.1-48, Jan. 1980.

SIMS, C.A. Money, income and causality. American Economic Review, v.62, n.2, p.540-552, 1972.

SOARES, A.R. Um século de economia açucareira: evolução da moderna agroindústria do açúcar em São Paulo, de 1877 a 1970. São Paulo: CLÍPER, 2000. $160 \mathrm{p}$.

STALDER, S.H.G. de M. Análise da participação do Brasil no mercado internacional de açúcar. Piracicaba, 1997. 121p. Dissertação (M.S) - Escola Superior de Agricultura "Luiz de Queiroz", Universidade de São Paulo.

STALDER, S.H.G. de M.; BURNQUIST, H.L. A importância dos subprodutos da canade-açúcar no desempenho do setor agroindustrial. Revista de Economia e Sociologia Rural, v.34, n.3/4, p.103-119, jul./dez. 1996.

STALDER, S.H.G.; BURNQUIST, H.L. Exportações de açúcar no Brasil: uma abordagem de elasticidade (compact disc). In: CONGRESSO BRASILEIRO DE ECONOMIA E SOCIOLOGIA RURAL, 35., Natal, 1997. Anais. Brasília: SOBER, 1997. p.289. 
SZMRECSÁNYI, T. Concorrência e complementariedade no setor açucareiro. Cadernos de Difusão de Tecnologias, v.6. n.2/3, p.165-182, maio/dez. 1989.

SZMRECSÁNYI, T. O planejamento da agroindústria canavieira do Brasil (19301975). São Paulo: HUCITEC/UNICAMP, 1979. 450p.

SZMRECSÁNYI, T.; MOREIRA, E.P. O desenvolvimento da agroindústria canavieira do Brasil desde a Segunda Guerra Mundial. Estudos Avançados, v.5, n.11, p.57$79,1991$.

UNITED STATES DEPARTMENT OF AGRICULTURE - USDA. Sugar: world markets and trade. http://www.fas.usda.gov/htp/sugar/sugar.html (15 Nov. 2001)

USINAS E DESTILARIAS DO OESTE PAULISTA - UDOP. Estatística. http://www.udop.com.br/estatistica/materias/producao_anos_brasil.htm (08 mar. 2002)

VEIGA FILHO, A. de A. Panorama das exportações de açúcar brasileiro. http://www.iea.sp.gov.br/ana-acuc0201.htm (15 nov. 2001)

ZEN, S. de. Integração entre os mercados de boi gordo e de carne bovina nas regiões centro-oeste e sudeste do Brasil. Piracicaba, 1997. 81p. Dissertação (M.S) - Escola Superior de Agricultura “Luiz de Queiroz”, Universidade de São Paulo. 